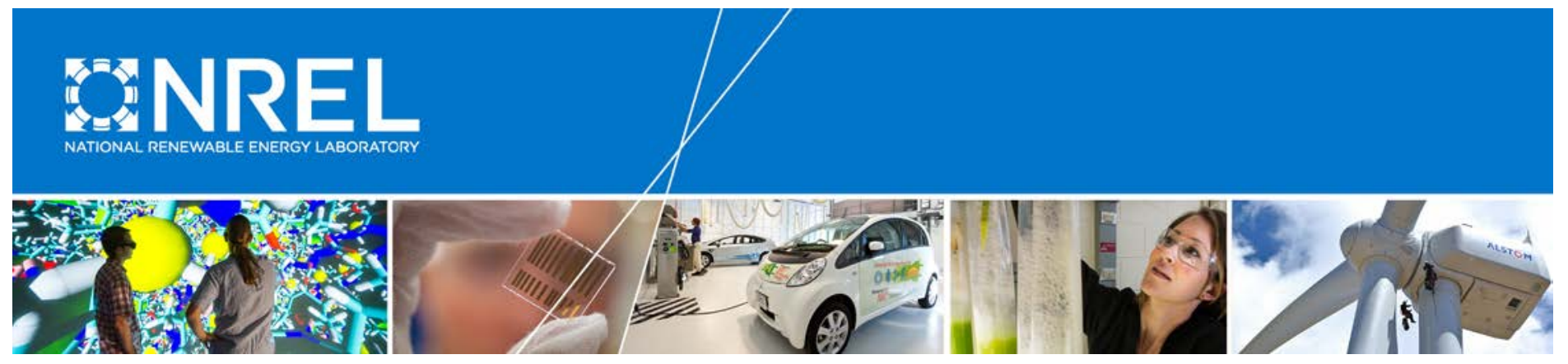

\title{
Zero Emission Bay Area (ZEBA) Fuel Cell Bus Demonstration Results: Sixth Report
}

Leslie Eudy, Matthew Post, and Matthew Jeffers National Renewable Energy Laboratory

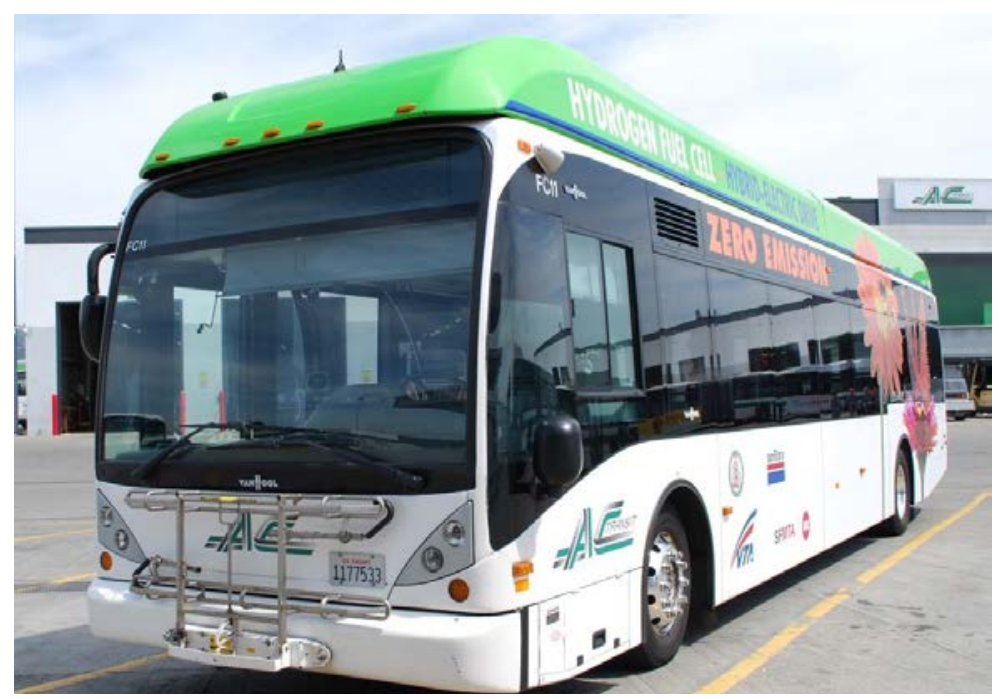

NREL is a national laboratory of the U.S. Department of Energy Office of Energy Efficiency \& Renewable Energy Operated by the Alliance for Sustainable Energy, LLC

This report is available at no cost from the National Renewable Energy Laboratory (NREL) at www.nrel.gov/publications.

Technical Report

NREL/TP-5400-68413

September 2017

Contract No. DE-AC36-08GO28308 


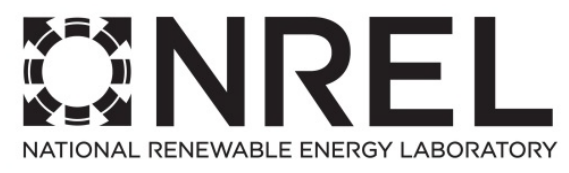

\section{Zero Emission Bay Area (ZEBA) Fuel Cell Bus Demonstration Results: Sixth Report}

Leslie Eudy, Matthew Post, and Matthew Jeffers National Renewable Energy Laboratory

Prepared under Task No. HT12.8210

NREL is a national laboratory of the U.S. Department of Energy Office of Energy Efficiency \& Renewable Energy Operated by the Alliance for Sustainable Energy, LLC

This report is available at no cost from the National Renewable Energy Laboratory (NREL) at www.nrel.gov/publications.

National Renewable Energy Laboratory 15013 Denver West Parkway Golden, CO 80401 303-275-3000 • www.nrel.gov
Technical Report NREL/TP-5400-68413

September 2017

Contract No. DE-AC36-08GO28308 


\section{NOTICE}

This report was prepared as an account of work sponsored by an agency of the United States government. Neither the United States government nor any agency thereof, nor any of their employees, makes any warranty, express or implied, or assumes any legal liability or responsibility for the accuracy, completeness, or usefulness of any information, apparatus, product, or process disclosed, or represents that its use would not infringe privately owned rights. Reference herein to any specific commercial product, process, or service by trade name, trademark, manufacturer, or otherwise does not necessarily constitute or imply its endorsement, recommendation, or favoring by the United States government or any agency thereof. The views and opinions of authors expressed herein do not necessarily state or reflect those of the United States government or any agency thereof.

This report is available at no cost from the National Renewable Energy Laboratory (NREL) at www.nrel.gov/publications.

Available electronically at SciTech Connect http:/www.osti.gov/scitech

Available for a processing fee to U.S. Department of Energy and its contractors, in paper, from:

U.S. Department of Energy

Office of Scientific and Technical Information

P.O. Box 62

Oak Ridge, TN 37831-0062

OSTI http://www.osti.gov

Phone: 865.576 .8401

Fax: 865.576.5728

Email: reports@osti.gov

Available for sale to the public, in paper, from:

U.S. Department of Commerce National Technical Information Service 5301 Shawnee Road

Alexandria, VA 22312

NTIS http://www.ntis.gov

Phone: 800.553 .6847 or 703.605 .6000

Fax: 703.605.6900

Email: orders@ntis.gov 


\section{Acknowledgments}

This evaluation at Alameda-Contra Costa Transit District (AC Transit) would not have been possible without the support and cooperation of many people. The authors thank the following individuals:

U.S. Department of Energy (DOE)

Jason Marcinkoski

Jim Alkire

U.S. Department of Transportation

Federal Transit Administration

Christina Gikakis

Sean Ricketson

DOE's National Renewable Energy

Laboratory

Keith Wipke

Jen Kurtz

AC Transit

Salvador Llamas

Roland Fecteau

Chris Durant

Jose Vega

Sergio Moreno

and many others
EnerDel

Tomasz Poznar

Golden Gate Transit

Steve Miller

Santa Clara Valley Transportation

Authority

Arthur Douwes

Jim Wilhelm

Christian Reif

San Mateo Transportation Agency

Elliott Rivas

Jerie Moeller

Linde

Nitin Natesan

Kyle McKeown

Center for Transportation and the

Environment

Jaimie Levin

Unless otherwise noted, all photos and illustrations by L. Eudy, NREL 


\section{Acronyms and Abbreviations}

$\begin{array}{ll}\text { AC Transit } & \text { Alameda-Contra Costa Transit District } \\ \text { Ah } & \text { amp-hours } \\ \text { CARB } & \text { California Air Resources Board } \\ \text { dge } & \text { diesel gallon equivalent } \\ \text { DOE } & \text { U.S. Department of Energy } \\ \text { FCEB } & \text { fuel cell electric bus } \\ \text { FCEV } & \text { fuel cell electric vehicle } \\ \text { FCPP } & \text { fuel cell power plant } \\ \text { ft } & \text { feet } \\ \text { FTA } & \text { Federal Transit Administration } \\ \text { GVWR } & \text { gross vehicle weight rating } \\ \text { hp } & \text { horsepower } \\ \text { HVAC } & \text { heating, ventilation, and air conditioning } \\ \text { in. } & \text { inches } \\ \text { kg } & \text { kilograms } \\ \text { kW } & \text { kilowatts } \\ \text { kWh } & \text { kilowatt hours } \\ \text { lb } & \text { pounds } \\ \text { MBRC } & \text { miles between roadcalls } \\ \text { mpg } & \text { miles per gallon } \\ \text { mph } & \text { miles per hour } \\ \text { NREL } & \text { National Renewable Energy Laboratory } \\ \text { PM } & \text { preventive maintenance } \\ \text { psi } & \text { pounds per square inch } \\ \text { RC } & \text { roadcall } \\ \text { SI } & \text { International System of Units } \\ \text { ZEBA } & \text { Zero Emission Bay Area } \\ & \end{array}$




\section{Definition of Terms}

Availability: The number of days the buses are actually available compared to the days that the buses are planned for operation expressed as percent availability.

Clean point: For each evaluation, NREL works with the project partners to determine a starting point — or clean point — for the data analysis period. The clean point is chosen to avoid some of the early and expected operations problems with a new vehicle going into service, such as early maintenance campaigns. In some cases, reaching the clean point may require 3 to 6 months of operation before the evaluation can start.

Deadhead: The miles and hours that a vehicle travels when out of revenue service with no expectation of carrying revenue passengers. Deadhead includes leaving or returning to the garage or yard facility and changing routes.

Miles between roadcalls (MBRC): A measure of reliability calculated by dividing the number of miles traveled by the number of roadcalls. (Also known as mean distance between failures.) $\mathrm{MBRC}$ results in the report are categorized as follows:

- Bus MBRC: Includes all chargeable roadcalls. Includes propulsion-related issues as well as problems with bus-related systems such as brakes, suspension, steering, windows, doors, and tires.

- Propulsion-related MBRC: Includes roadcalls that are attributed to the propulsion system. Propulsion-related roadcalls can be caused by issues with the fuel cell, batteries, and electric drive.

- Fuel cell-related MBRC: Includes roadcalls attributed to the fuel cell system and balance of plant only.

Revenue service: The time when a vehicle is available to the general public with an expectation of carrying fare-paying passengers. Vehicles operated in a fare-free service are also considered revenue service.

Roadcall: A failure of an in-service bus that causes the bus to be replaced on route or causes a significant delay in schedule. The analysis includes chargeable roadcalls that affect the operation of the bus or may cause a safety hazard. Non-chargeable roadcalls can be passenger incidents that require the bus to be cleaned before going back into service, or problems with an accessory such as a farebox or radio. 


\section{Executive Summary}

This report presents results of a demonstration of fuel cell electric buses (FCEBs) operating in Oakland, California. Alameda-Contra Costa Transit District (AC Transit) leads the Zero Emission Bay Area (ZEBA) demonstration that includes 13 advanced-design fuel cell buses and two hydrogen fueling stations. The FCEBs in service at AC Transit are 40-foot, low-floor buses built by Van Hool with a hybrid electric propulsion system that includes a UTC Power-designed PC40 fuel cell power system and EnerDel lithium-based energy storage system. The buses began revenue service in May 2010.

The ZEBA partners are collaborating with the U.S. Department of Energy (DOE) and DOE's National Renewable Energy Laboratory (NREL) to evaluate the buses in revenue service. NREL has been evaluating FCEBs under funding from DOE and the U.S. Department of Transportation's Federal Transit Administration (FTA). NREL uses a standard data-collection and analysis protocol originally developed for DOE heavy-duty vehicle evaluations. ${ }^{1}$ NREL has published five previous reports describing operation of these buses. This report presents new and updated results covering data from January 2016 through December 2016.

The focus of this evaluation is to compare the performance of the FCEBs to that of conventional technology buses and to track progress over time toward meeting the technical targets set by DOE and FTA. In the commercialization process that begins at technology readiness level (TRL) 1-basic research/concept - and ends at TRL 9-commercial deployment, NREL considers the ZEBA buses to be at TRL 7. At this point of development, the manufacturers' goals for the demonstration are to verify that the FCEB performance meets the technical targets and identify any issues that need to be resolved. NREL collects data on 10 Gillig conventional diesel buses for a baseline comparison at AC Transit.

Since the last report, there have been multiple accomplishments.

- The FCEBs together have surpassed 1.5 million miles (1,781,384 miles) and 204,163 hours on the fuel cell power systems since being placed into service.

- AC Transit has safely fueled its FCEBs 3,428 times with more than $76,932 \mathrm{~kg}$ of hydrogen during the data period.

- The 13 fuel cell power plants (FCPPs) continue to accumulate high hours of service. Six FCPPs have surpassed the DOE/FTA 2016 target of 18,000 hours, with one having accumulated 23,423 hours by the end of the data period for the report. This is a record number of hours documented to date on a fuel cell in a transit application. All of the FCPPs have surpassed 14,000 hours of operation with the exception of FC13, which joined the AC Transit fleet last year.

This sixth results report provides data analysis summaries of FCEB operations from January 2016 through December 2016. Table ES-1 provides a summary of the data period results presented in this report.

\footnotetext{
${ }^{1}$ Fuel Cell Transit Bus Evaluations: Joint Evaluation Plan for the U.S. Department of Energy and the Federal Transit Administration, NREL/MP-560-49342-1, November 2010, http://www.nrel.gov/docs/fy11osti/49342-1.pdf.
} 
Table ES-1. Summary of Data Period Results ${ }^{a}$

\begin{tabular}{|l|c|c|}
\hline \multicolumn{1}{|c|}{ Data Item } & FCEB & Diesel Gillig \\
\hline Number of buses & 13 & 10 \\
\hline Data period & $1 / 16-12 / 16$ & $1 / 16-12 / 16$ \\
\hline Number of months & 12 & 12 \\
\hline Total mileage in period & 447,720 & 523,220 \\
\hline Average monthly mileage per bus & 2,870 & 4,360 \\
\hline Total fuel cell operating hours & 52,102 & $\mathrm{~N} / \mathrm{A}$ \\
\hline Average bus operating speed (mph) & 8.6 & $\mathrm{~N} / \mathrm{A}$ \\
\hline Availability (85\% is target) & 80 & 90 \\
\hline Fuel economy (miles/kg) & 5.42 & $\mathrm{~N} / \mathrm{A}$ \\
\hline Fuel economy (miles/dge ${ }^{\mathrm{b}}$ ) & 6.12 & 4.21 \\
\hline Miles between roadcalls (MBRC) - bus & 4,708 & 6,669 \\
\hline MBRC - propulsion only & 8,327 & 13,479 \\
\hline MBRC - fuel cell system only ${ }^{\mathrm{c}}$ & 21,522 & $\mathrm{~N} / \mathrm{A}$ \\
\hline Fuel cost (\$/mile) & 1.30 & 0.37 \\
\hline Total maintenance cost (\$/mile) & d & 0.56 \\
\hline $\begin{array}{l}\text { Maintenance cost - propulsion only } \\
\text { (\$/mile) }\end{array}$ & 1.11 & 0.16 \\
\hline $\begin{array}{l}\text { Total maintenance cost including extended } \\
\text { support and extra labor costs (\$/mile) }\end{array}$ & 0.38 & - \\
\hline
\end{tabular}

${ }^{a}$ Issues with two FCEBs during the data period resulted in lower numbers for some performance metrics.

${ }^{\mathrm{b}}$ Diesel gallon equivalent.

${ }^{\mathrm{c}}$ Cumulative data from September 2010.

${ }^{\mathrm{d}}$ Work order maintenance cost.

${ }^{\mathrm{e}}$ Extended support from US Hybrid and EnerDel for the fuel cell buses began in April 2014.

Overall, the FCEBs had an average fuel economy of 5.42 miles per kilogram of hydrogen, which equates to 6.12 miles per diesel gallon equivalent. These results indicate that the FCEBs have an average fuel economy that is $45 \%$ higher than that of the Gillig diesel buses.

Fuel cost for hydrogen remains much higher than the cost of diesel— $\$ 7.03$ per kilogram of hydrogen compared to $\$ 1.55$ per gallon for diesel for the report data period. The cost of hydrogen has decreased slightly since the previous report. The average cost of diesel fuel has also dropped. Fuel cost calculates to $\$ 1.30$ per mile for the FCEBs compared to $\$ 0.37$ per mile for the Gillig diesel buses. The costs provided in this report reflect AC Transit's experience, which may not be the same as that of other agencies. Fuel costs for transit agencies depend on negotiated agreements between fuel providers and can vary widely based on a number of factors such as fuel source and station design.

The overall availability for the FCEBs has increased compared to what was documented in the last report $-80 \%$ compared to $74 \%$ from the previous data period. The availability for the individual ZEBA FCEBs ranged from a low of 51\% to a high of $94 \%$. The Gillig diesel buses had an availability of $90 \%$ during the period.

Reliability, measured as miles between roadcalls (MBRC), continues to show improvement. When evaluating cumulative totals since the buses first went into service, the overall bus MBRC for the ZEBA FCEBs is showing a slow increase over time and has surpassed the DOE/FTA ultimate target of 4,000 miles. The cumulative fuel cell MBRC shows a steady increase and has passed the DOE/FTA ultimate target of 20,000 miles. 
In addition to analyzing the FCEB performance, NREL provides a cost analysis and comparison. The current costs for FCEB technology — both capital and operating costs - are still much more than the costs of conventional diesel technology. This is expected when comparing a very mature technology, like diesel, to new technologies in the development stage. The FCEBs are now out of the original warranty period resulting in an increase in operating costs.

The FCEB maintenance costs were more than twice that of the Gillig diesel buses. The systems with the highest percentage of maintenance costs for the fuel cell buses were propulsion-related; general air system; and cab, body, and accessories. The Gillig diesel bus systems with the highest percentage of maintenance costs were propulsion-related; cab, body, and accessories; and preventive maintenance inspections. High parts costs are the primary reason for the higher cost per mile for the FCEBs. Another factor is the added labor hours for troubleshooting issues and for training. As the agency ramps up training outside the original group of mechanics, labor hours can be double or triple depending on the number of maintenance staff being trained. These labor costs will eventually drop and stabilize as staff experience increases.

Throughout the demonstration, the ZEBA buses have incurred some costs that fall outside of the typical maintenance costs. These costs were for activities including research and training, shuttling the FCEBs between depots, and fueling and cleaning. These costs are considered nonrecurring costs for the FCEBs; however, they add to the current cost per mile of the ZEBA buses. NREL reported on these costs in detail in the previous reports. The non-recurring costs for the ZEBA fleet have dropped dramatically over time. During the data period, the added cost was primarily for shuttling FCEBs between depots, which added $\$ 0.04$ per mile to the costs. Once the Emeryville maintenance bay is completed, shuttling the buses between depots will not be necessary and the costs for all non-recurring activities should be completely eliminated. When factoring in the costs for the extended warranties and other costs, the current cost to operate the FCEBs comes to $\$ 2.28$ per mile.

Advanced technology demonstrations typically experience challenges and issues that need to be resolved. Challenges for AC Transit included the following.

Transition of maintenance to transit staff-The transition of knowledge from the manufacturers to the transit staff is essential to commercializing the technology. AC Transit continues to train increasing numbers of technicians to maintain the ZEBA buses. AC Transit has assigned a dedicated supervisor and mechanic at each depot to lead the work on the FCEBs. These employees handle the training and bring in other staff as needed. Much of the hands-on training is performed on an as-needed basis when FCEBs need to have repairs done. Any manufacturer support can be provided through remote diagnosis. The agency continues to experience challenges with troubleshooting new issues with the buses. This can be labor intensive and the downtime lowers availability for the fleet. Work orders can have multiple mechanics logging hours when several may have been in training. In this case, the time and cost of the repair will be artificially high. This added labor cost typically increases after the transit staff takes over maintenance work but drops over time as the staff becomes more familiar with the technology. This is also the case for scheduled preventive maintenance (PM). AC Transit reports that a minor PM for the buses takes approximately 3 hours and a major PM is estimated at 8 hours. Over the data period, the agency has been training a number of staff in conducting scheduled maintenance tasks. In one case, labor for a single PM totaled 23 hours indicating a 
number of staff being trained. During 2016, AC Transit conducted 81 major PMs and 80 minor PMs on the ZEBA buses (approximately 6 of each per bus). Had those PMs been accomplished at the estimated labor hours, the scheduled maintenance cost would have been $\$ 0.14$ per mile as opposed to $\$ 0.19$ per mile.

Extended manufacturer support-AC Transit funded extended support from the manufacturers through a $\$ 1.8$ million grant through the National Fuel Cell Bus Program. AC Transit negotiated agreements with US Hybrid and EnerDel and set up purchase orders with Siemens, Van Hool, and Luxfer for parts as needed. The time periods for these agreements have now ended. AC Transit received authorization to continue using the funds for this support but will have to negotiate new agreements with the manufacturers. The maintenance totals in the report show the cost of this extended support.

Parts supply and cost-AC Transit continues to experience some issues with availability of bus components that have a long lead time for delivery. AC Transit has addressed this by purchasing some parts to keep in stock. The agency is also working toward sourcing parts directly from the component manufacturer. In addition, parts costs have risen since the buses surpassed the warranty period. The industry could aid in cutting costs by standardizing bus-related components within platforms. Shared components for bus models will increase manufacturing quantities and improve inventory availability. This could result in lower cost and reduced downtime.

Air compressor issues-Multiple buses have had issues with the air compressor and converter for the bus air system. Unlike the diesel version, the compressor and converter for the FCEBs is a combined unit—when one part fails, the entire unit must be replaced. AC Transit believes the air system is reaching end of life because it seems to be failing on all of the buses at the same time. The agency is tracking the odometers at failure to help anticipate the issue in the future. This will allow AC Transit to order long-lead-time parts early to reduce downtime.

Fuel cell blower issues-Most of the buses experienced issues with the intake pump that supplies air to the fuel cell. This pump is part of the balance of plant inside the fuel cell module. The vendor for the part was rebuilding the pumps; however, the rebuilt pumps were not lasting as long as new ones. To address the issue, AC Transit located another vendor for the part. The turnaround time is longer, but the part is higher quality and works well.

Extended downtime-AC Transit has experienced issues with specific buses that resulted in extended downtime. During this report data period, several buses were out of service for long periods for maintenance activities that are considered to be atypical. Problems included issues with the fuel cell cooling system, air intake, and high voltage cables. The agency worked with its suppliers to identify and address these issues. 


\section{Table of Contents}

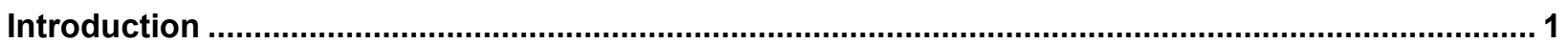

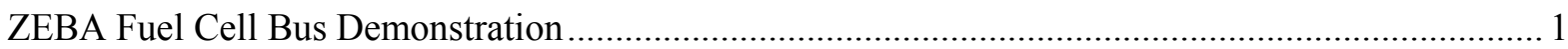

FCEB Development Process_Technology Readiness Levels ................................................. 4

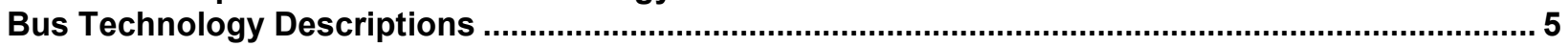

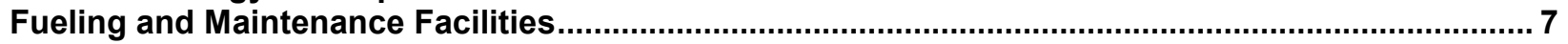

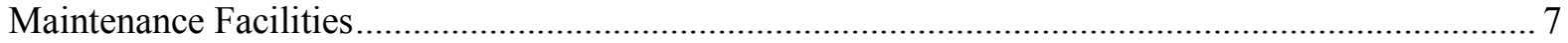

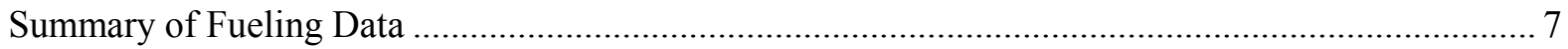

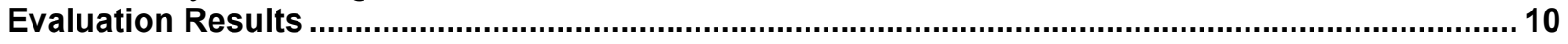

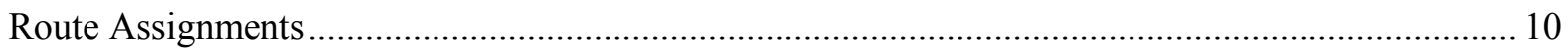

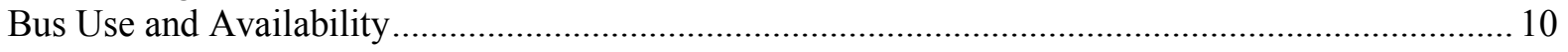

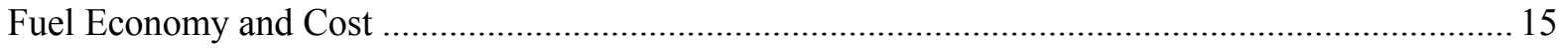

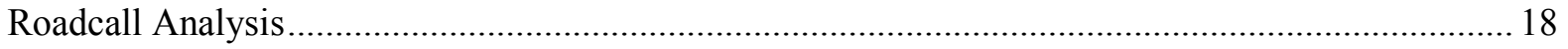

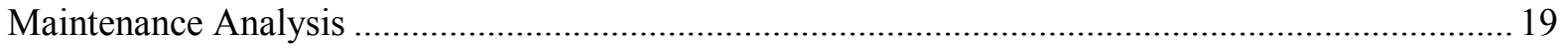

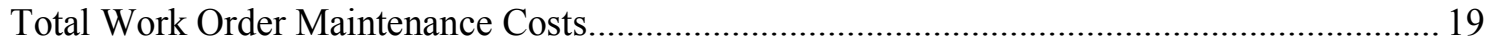

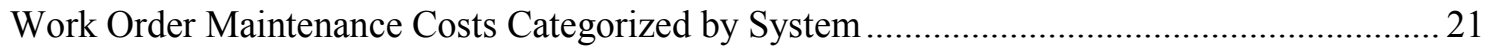

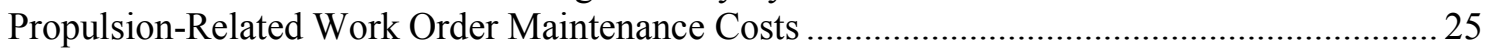

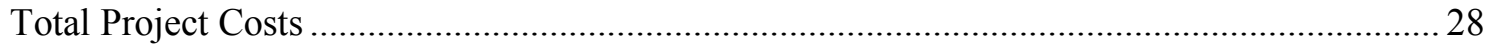

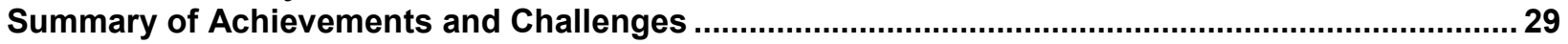

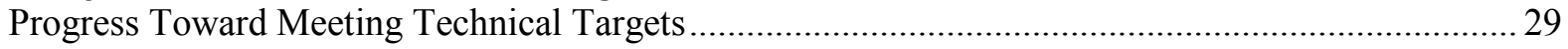

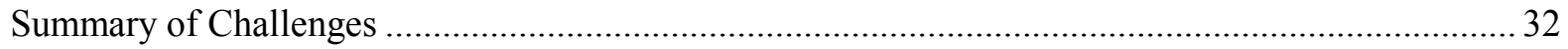

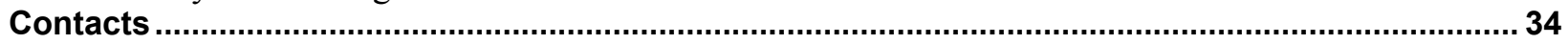

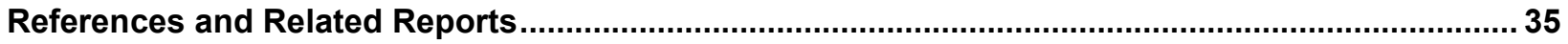

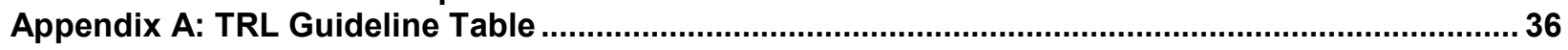

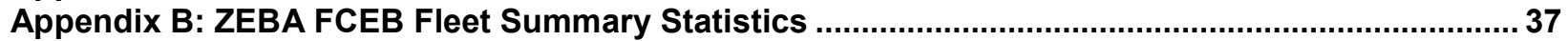

Appendix C: ZEBA FCEB Fleet Summary Statistics_SI Units ..................................................... 43

Appendix D: ZEBA FCEB Monthly Maintenance Analysis Graphs ................................................. 44

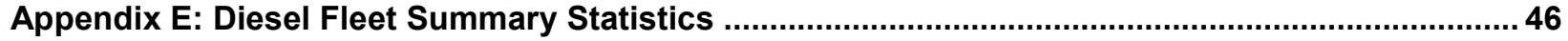

Appendix F: Diesel Fleet Summary Statistics_SI Units.................................................................. 51

Appendix G: Diesel Monthly Maintenance Analysis Graphs ........................................................... 52

Appendix H: Charts for Entire In-Service Period (All Data) .......................................................... 54 


\section{Introduction}

Alameda-Contra Costa Transit District (AC Transit) is leading a demonstration of fuel cell electric buses (FCEBs) in the San Francisco Bay Area of California. The Zero Emission Bay Area (ZEBA) demonstration includes 13 advanced-design fuel cell buses and two hydrogen fueling stations. The buses began revenue service in May 2010. Several Bay Area transit agencies - including Golden Gate Transit, Santa Clara Valley Transportation Authority, and San Mateo County Transit District - participate in the ZEBA demonstration. The agencies provide funding as well as participate in data sharing discussions and training activities.

The ZEBA partners are collaborating with the U.S. Department of Energy (DOE) and DOE's National Renewable Energy Laboratory (NREL) to evaluate the buses in revenue service. NREL has been evaluating FCEBs under funding from DOE and the U.S. Department of Transportation's Federal Transit Administration (FTA). NREL uses a standard data-collection and analysis protocol originally developed for DOE heavy-duty vehicle evaluations. This protocol was documented in a joint evaluation plan for transit bus evaluations. ${ }^{2}$ The objectives of these evaluations are to provide comprehensive, unbiased evaluation results of fuel cell bus development and performance compared to conventional baseline vehicles. NREL published five earlier reports on this demonstration in August 2011, July 2012, May 2014, July 2015, and June $2016 .{ }^{3}$ This report is an update to the previous reports and focuses on data from January 2016 through December 2016.

\section{ZEBA Fuel Cell Bus Demonstration}

The California Air Resources Board's (CARB's) 2000 "Fleet Rule for Transit Agencies"4 has been the primary reason for demonstrations of FCEBs in the state of California. This rule set more stringent emission standards for new urban bus engines and promoted advances in the cleanest technologies, specifically zero-emission buses. In 2006, CARB updated the transit rule and added a requirement for an advanced zero-emission bus demonstration for the larger California agencies. As a result, the five largest transit agencies in the San Francisco Bay Area formed the ZEBA demonstration group. In addition to the four previously mentioned transit agencies, San Francisco Municipal Transit Authority is a voluntary participant because the agency already owns and operates a large fleet of zero-emission electric trolley buses. The ZEBA partners' operating areas are shown in Figure 1.

\footnotetext{
${ }^{2}$ Fuel Cell Transit Bus Evaluations: Joint Evaluation Plan for the U.S. Department of Energy and the Federal Transit Administration, NREL/MP-560-49342-1, November 2010, http://www.nrel.gov/docs/fy11osti/49342-1.pdf.

${ }^{3}$ See the "References and Related Reports" section for links to the five previous reports on the ZEBA Demonstration.

${ }^{4}$ Fact Sheet: Fleet Rule for Transit Agencies: Urban Bus Requirements, California Air Resources Board, http://www.arb.ca.gov/msprog/bus/ub/ubfactsheet.pdf.
} 


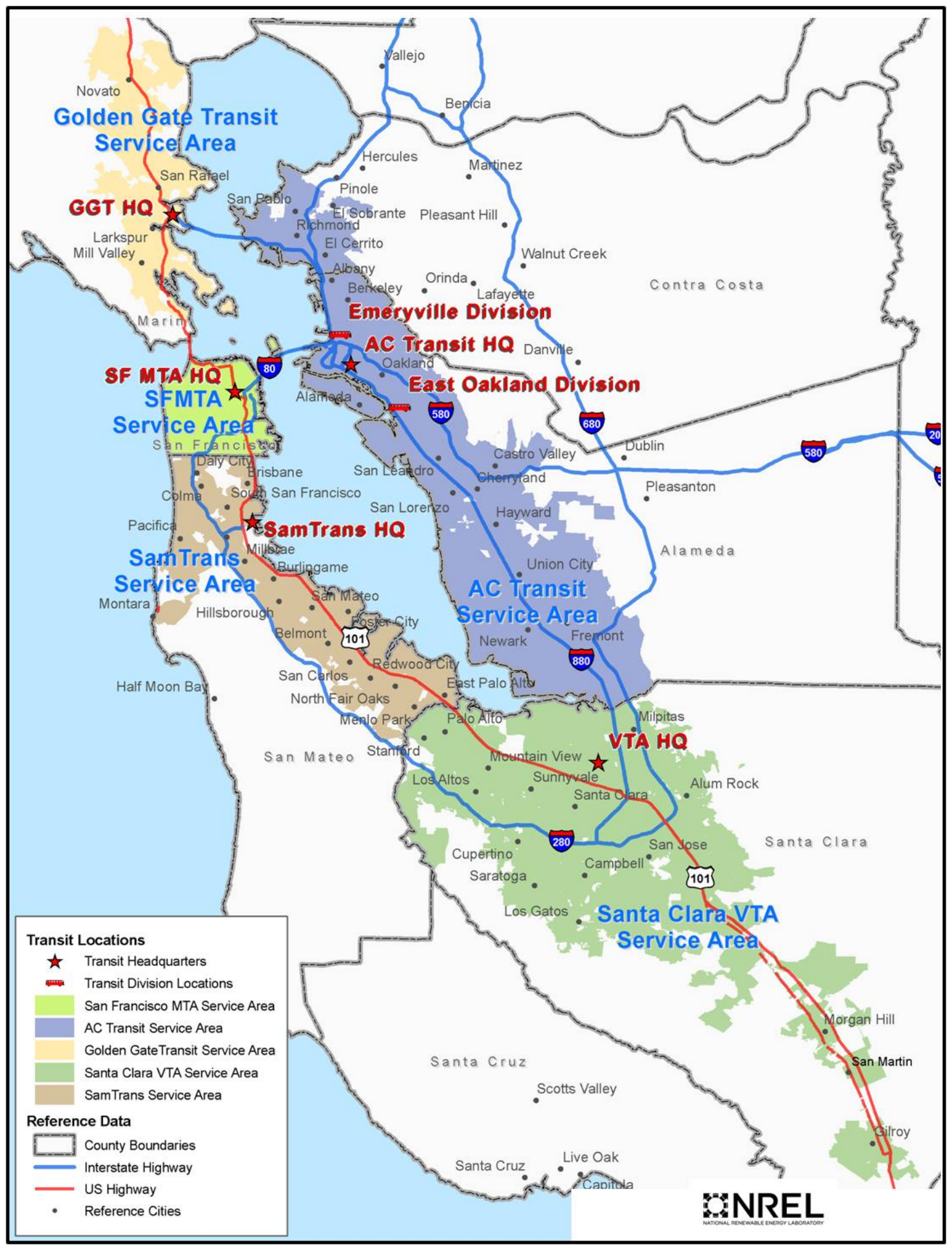

Figure 1. Map of ZEBA transit partner service areas

The ZEBA demonstration group is supported through funding and planning by the Metropolitan Transportation Commission, the Bay Area Air Quality Management District, CARB, the California Energy Commission, and the FTA (including early funding under the National Fuel Cell Bus Program). AC Transit was awarded a grant in the final round of the National Fuel Cell 
Bus Program funding. Managed through one of the non-profit consortia-the Center for Transportation and the Environment - the $\$ 1.8$ million award provides funds to support the continued operation of the FCEB fleet.

The goals for the ZEBA demonstration include the following:

- Operating performance: Demonstrate that FCEBs can fulfill or exceed the operating requirements and standards of baseline diesel buses from the perspective of drivers and passengers (i.e., schedule adherence, vehicle handling, and passenger acceptance).

- Fleet availability: Match the "A.M. Pullout" fleet availability percentages of baseline diesel buses with a minimum fleet size of 12 buses.

- Fleet reliability: Match the miles between roadcalls (MBRC) of diesel buses for the bus as a whole and for the propulsion system category with a minimum fleet size of 12 buses.

- Fuel economy: Exceed the fuel economy of baseline diesel buses.

- Infrastructure support: Develop renewable sources of hydrogen, and demonstrate safe fueling systems and throughput (fueling speeds) equivalent to diesel fueling.

- Maintenance costs: Track labor and material costs to compare with baseline diesel buses across applicable expense categories.

AC Transit's demonstration began in 2010 with 12 FCEBs. Van Hool built 16 buses of this configuration: 12 for AC Transit and 4 for Connecticut Transit in Hartford (funded through the National Fuel Cell Bus Program). At the end of the Connecticut demonstration in 2013, Connecticut Transit transferred one of its buses to AC Transit. That bus went into service in late 2015, bringing the ZEBA fleet to 13 buses. 


\section{FCEB Development Process-Technology Readiness Levels}

NREL has developed a guideline for assessing the technology readiness level (TRL) for FCEBs. ${ }^{5}$ Figure 2 provides a graphic representation of this process. (Appendix A provides the TRL guideline table tailored for FCEB commercialization.) The guideline considers the FCEB as a whole and does not account for differing TRLs for separate components or sub-systems. Some sub-systems may include off-the-shelf components that are considered commercial, while other sub-systems may feature newly designed components at an earlier TRL.

\section{Commercialization Process}

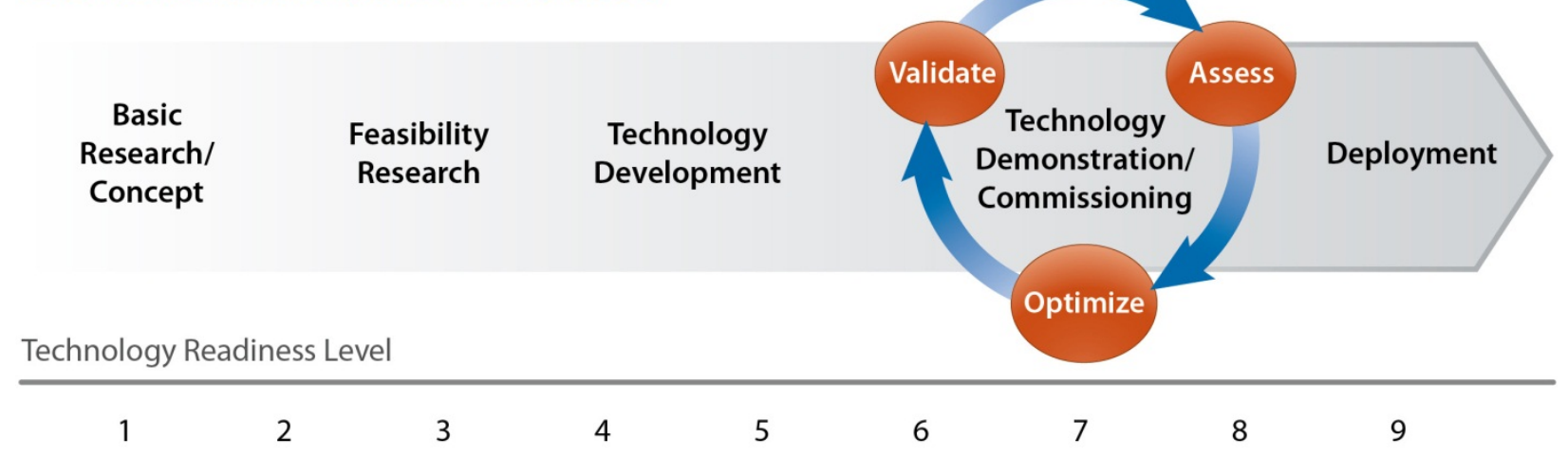

Figure 2. Graphic representation of the commercialization process developed for FCEBs

NREL considers the ZEBA buses to be at TRL 7 because manufacturers that were experienced with FCEB and hybrid technology development led the design of the bus, and the deployment includes the 13-bus ZEBA fleet. These buses represent a full-scale validation in a relevant environment. NREL's goal in evaluating FCEBs is to document the performance and track progress over time toward meeting the technical targets. NREL collects data on conventional buses at each demonstration site for a baseline comparison. This is important primarily because fuel economy is highly dependent on duty cycle, but also because maintenance practices can be different from site to site. The best comparisons need to include buses operated in similar service at the same operating division. The most accurate comparison would be between buses of the same manufacturer, model, production year, and mileage. In that case, the only difference between the FCEBs and baseline buses would be the propulsion system. This type of baseline comparison is not always possible. For the ZEBA evaluation, NREL collects data on ten 40-foot Gillig diesel buses for a baseline comparison to the FCEBs.

\footnotetext{
${ }^{5}$ Fuel Cell Buses in U.S. Transit Fleets: Current Status 2012, NREL/TP-5600-56406, November 2012, http://www.nrel.gov/docs/fy13osti/56406.pdf.
} 


\section{Bus Technology Descriptions}

Table 1 provides bus system descriptions for the fuel cell and diesel buses that were studied in this evaluation. The FCEBs in service at AC Transit (Figure 3) are 40-foot, low-floor buses built by Van Hool with a hybrid electric propulsion system that includes a fuel cell power system that was originally designed by UTC Power. US Hybrid provides service and support to the fuel cell power systems through a maintenance agreement with AC Transit. The FCEBs have a fuel cell dominant hybrid electric propulsion system in a series configuration. Van Hool fully integrated the hybrid design using a Siemens ELFA 2 hybrid system; a fuel cell power system; and an advanced lithium-based energy storage system by EnerDel. The Gillig diesel buses have Cummins engines that meet U.S. Environmental Protection Agency 2010 emissions standards using a diesel particulate filter and selective catalytic reduction. Figure 4 shows one of the Gillig diesel buses.

Table 1. Fuel Cell and Diesel Bus System Descriptions

\begin{tabular}{|c|c|c|}
\hline Vehicle System & FCEB & Diesel Gillig \\
\hline Number of buses & 13 & 10 \\
\hline Bus manufacturer/model & $\begin{array}{c}\text { Van Hool A300L FC low } \\
\text { floor }\end{array}$ & Gillig low floor \\
\hline Model year & 2010 & 2013 \\
\hline Length/width/height & $40 \mathrm{ft} / 102 \mathrm{in.} / 136 \mathrm{in}$. & $40 \mathrm{ft} / 102 \mathrm{in.} / 122 \mathrm{in}$. \\
\hline GWWR/curb weight & $39,350 \mathrm{lb} / 31,400 \mathrm{lb}$ & $39,600 \mathrm{lb}$ \\
\hline Passenger capacity & $\begin{array}{c}33 \text { seated or } 29 \text { seated plus } \\
2 \text { wheelchairs }\end{array}$ & $\begin{array}{c}37 \text { seated or } 29 \text { seated } \\
\text { plus } 2 \text { wheelchairs }\end{array}$ \\
\hline Hybrid system & $\begin{array}{c}\text { Siemens ELFA } 2 \text { integrated } \\
\text { by Van Hool, } \\
\text { 2-AC induction motors, } 85 \\
\text { kW each }\end{array}$ & N/A \\
\hline Fuel cell or engine & UTC Power PC40 & Cummins ISL, 8.9L \\
\hline Rated power & $\begin{array}{c}\text { Fuel cell power system: } 120 \\
\text { kW }\end{array}$ & 280 hp @ 2,200 rpm \\
\hline Energy storage & $\begin{array}{l}\text { Battery: EnerDel, lithium ion } \\
\text { Rated energy: } 21 \mathrm{kWh} \\
\text { Rated power: } 76 \text { to } 125 \mathrm{~kW}\end{array}$ & N/A \\
\hline Accessories & Electrical & Mechanical \\
\hline Emissions equipment & None & $\begin{array}{c}\text { Diesel particulate filter } \\
\text { and selective catalytic } \\
\text { reduction }\end{array}$ \\
\hline Braking & Regenerative & Retarder \\
\hline Fuel capacity & $\begin{array}{c}\text { Eight roof mounted, Luxfer, } \\
\text { type } 3 \text { tanks; 5,000 psi rated } \\
40 \mathrm{~kg} \text { hydrogen }\end{array}$ & 120 gal diesel \\
\hline Bus purchase cost & $\$ 2.5$ million $^{a}$ & $\$ 413,826$ \\
\hline
\end{tabular}

${ }^{a}$ This represents AC Transit's per-bus purchase price for the ZEBA buses in 2010. More recent orders for FCEBs show a cost of $\$ 1.8$ million. 


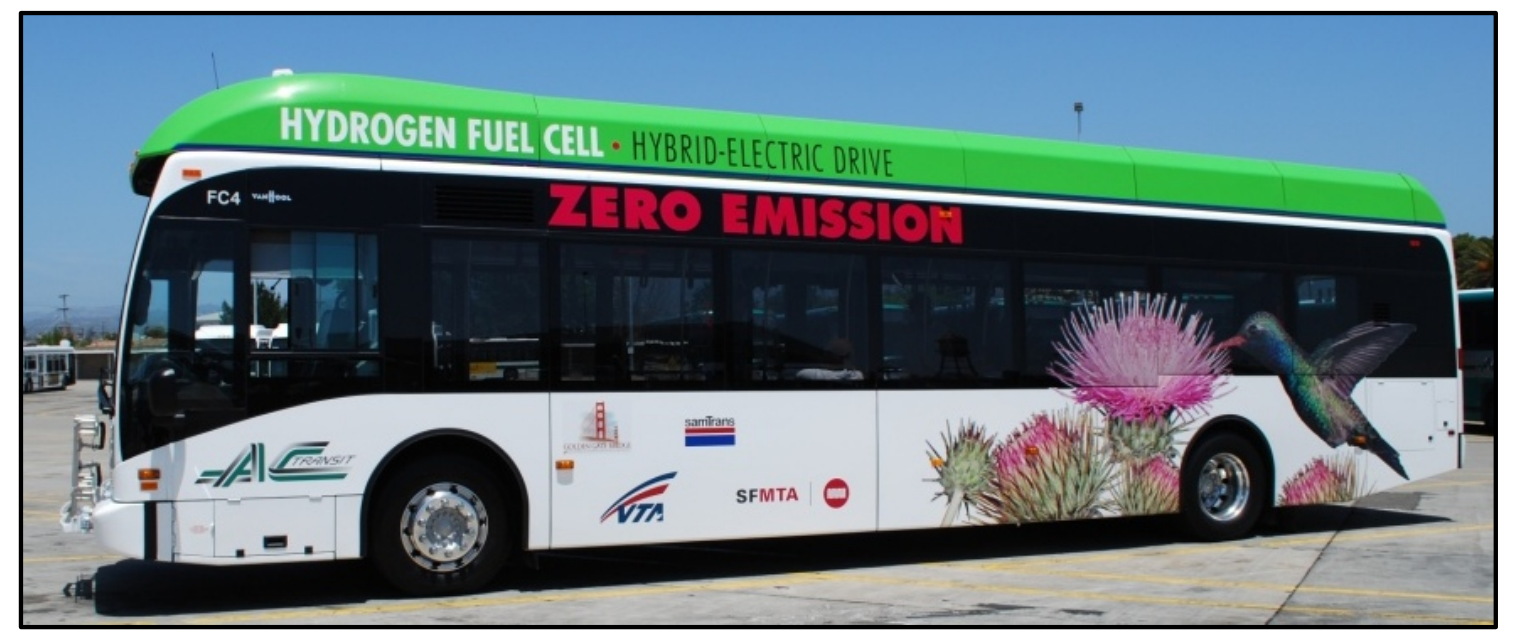

Figure 3. AC Transit fuel cell electric bus

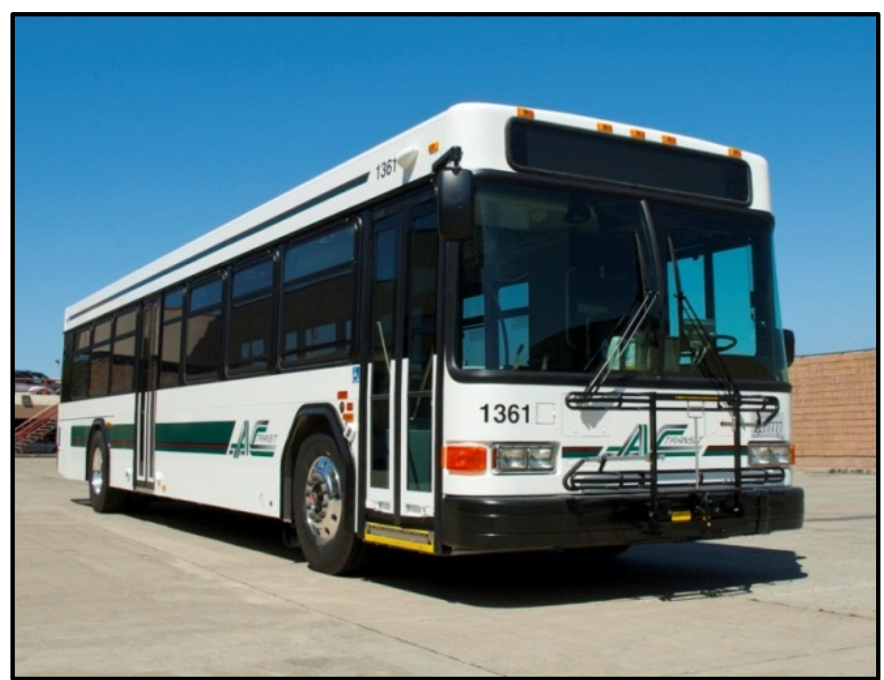

Figure 4. AC Transit Gillig diesel bus. Photo courtesy of AC Transit 


\section{Fueling and Maintenance Facilities}

AC Transit provides fuel for its ZEBA fleet from two hydrogen stations: one at the Emeryville Division and another at the Oakland Division. The stations, both designed and built by Linde, LLC, provide hydrogen through a combination of delivered liquid hydrogen and hydrogen produced via water electrolysis. The Emeryville station also provides hydrogen for light-duty vehicles that can be fueled at a dispenser located outside the facility. The Oakland station only serves the bus fleet and has the hydrogen dispensers located at the end of the diesel fueling island. This allows the FCEBs to be integrated into the standard process for fueling and cleaning at the end of the day. Detailed descriptions of the AC Transit hydrogen stations were included in the previous reports. AC Transit is in the process of upgrading the Emeryville station to move the bus hydrogen dispensers to be in-line with the fueling island. The agency also plans to upgrade the storage cylinders during the downtime.

\section{Maintenance Facilities}

AC Transit maintains the FCEBs in a maintenance bay at the Oakland Seminary Division. This bay was modified to accommodate hydrogen-fueled buses for the earlier demonstration. While the fleet was operated out of the Emeryville Division, AC Transit maintenance staff had to shuttle the buses between the divisions, which resulted in additional labor charges. The agency has begun an upgrade at the Emeryville Division to convert two bays for safe maintenance of hydrogen-fueled buses. Once this modification is complete, all maintenance for the buses stationed at Emeryville will be handled there without the need to shuttle the buses between depots. AC Transit expects the construction to be completed in June 2017.

\section{Summary of Fueling Data}

The Emeryville station was used to fuel all of the ZEBA buses from the time it was commissioned in August 2011 until December 2014, when the Oakland fueling station was completed. At that time, AC Transit transferred a portion of the buses from Emeryville to Oakland. Figure 5 shows the average daily hydrogen dispensed by month for the report data period (January 2016-December 2016). The averages only include days when hydrogen was dispensed; zero-use days were excluded. The graph includes fuel dispensed from both stations. During this period, the buses were fueled 3,428 times for a total of 76,932 kg of hydrogen. The average amount per fueling was $22.4 \mathrm{~kg}$. Figure 6 tracks the total hydrogen dispensed into the buses each month by station. Figure 7 shows the cumulative hydrogen dispensed into the buses since the beginning of the demonstration. At the end of 2016, the fleet-wide total was more than $277,000 \mathrm{~kg}$ of hydrogen. 


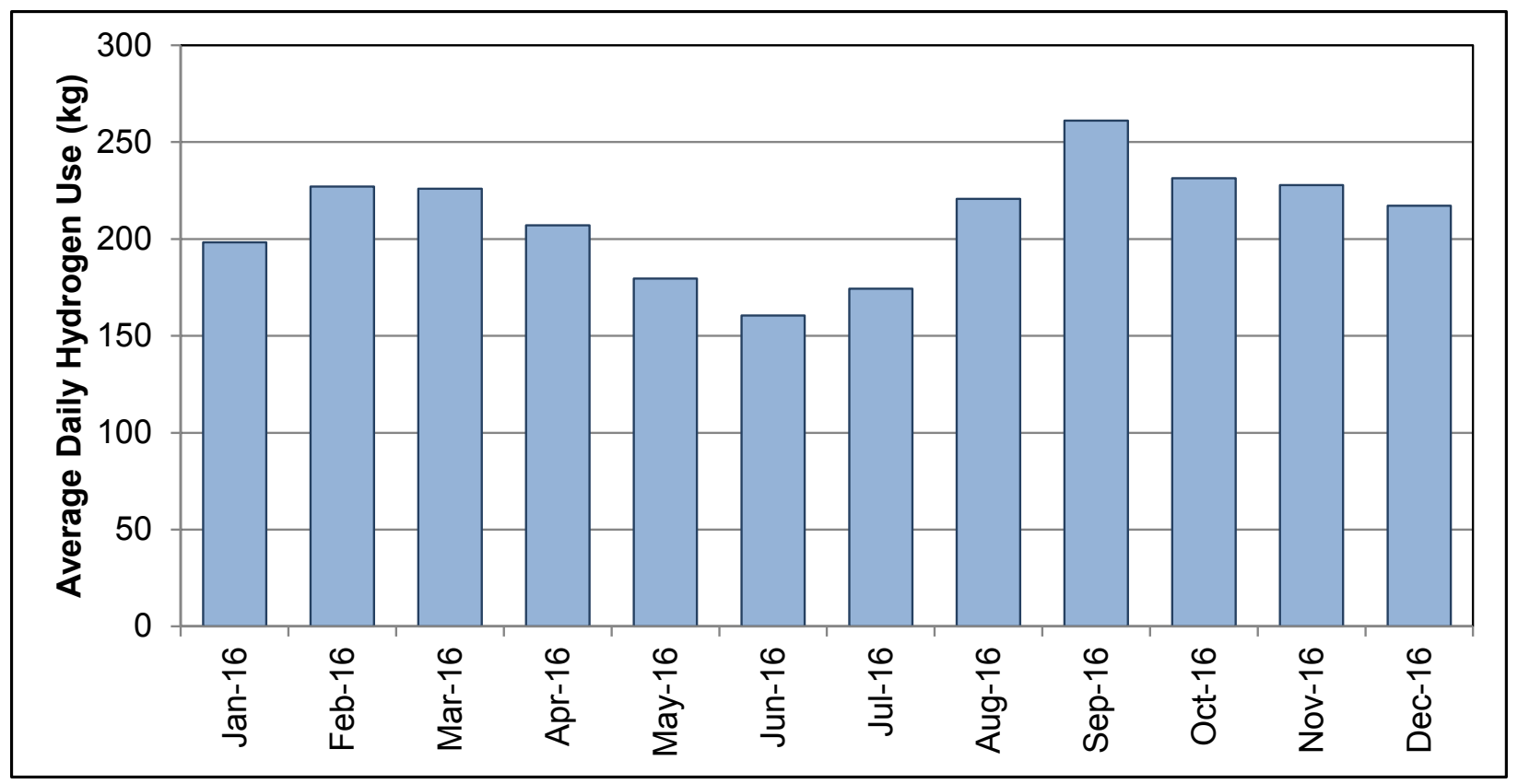

Figure 5. Average hydrogen dispensed per day at AC Transit's hydrogen stations (excluding $0 \mathrm{~kg}$ days)

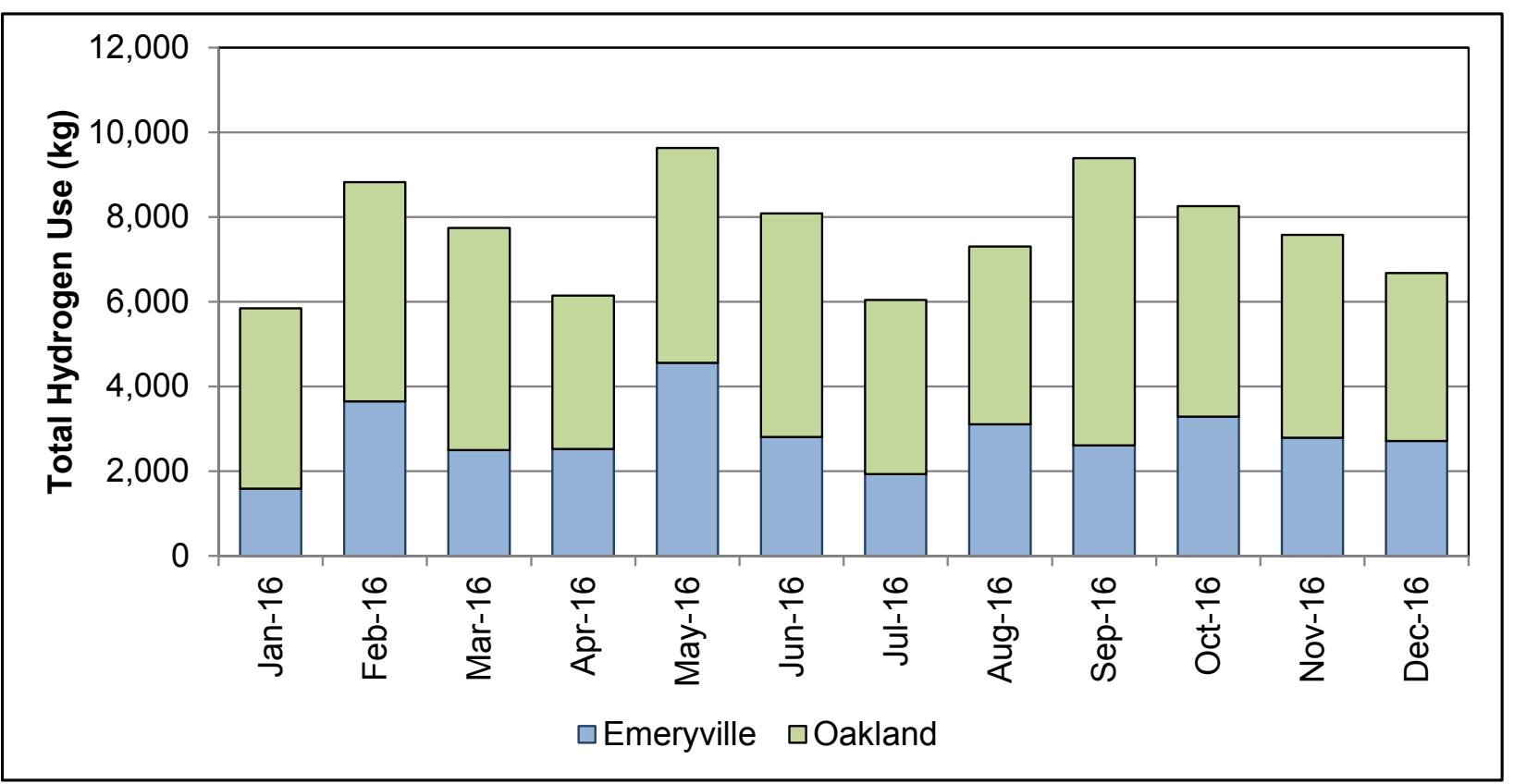

Figure 6. Total hydrogen dispensed per month at AC Transit's hydrogen stations 


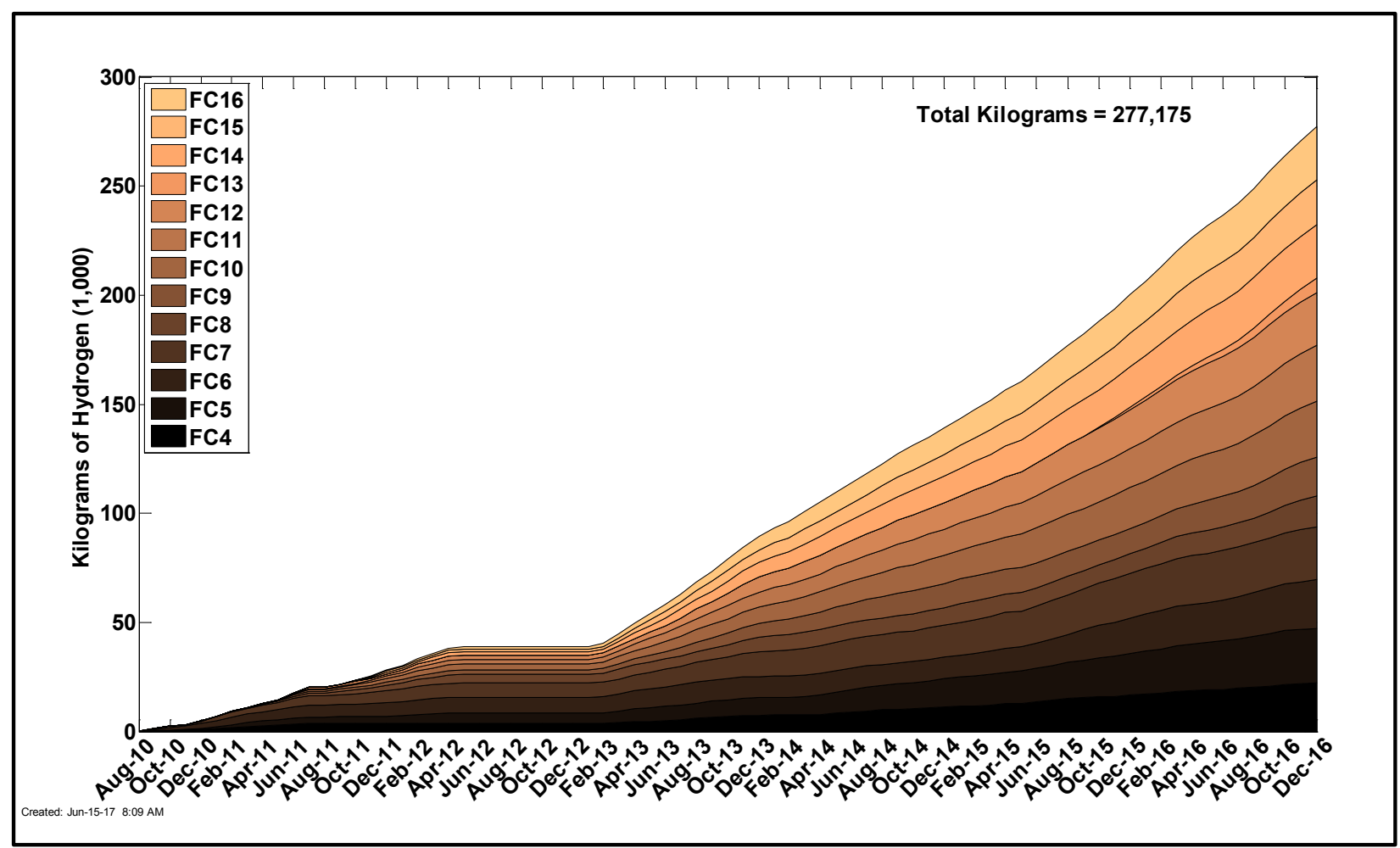

Figure 7. Cumulative hydrogen dispensed into the buses through December $2016^{6}$

\footnotetext{
${ }^{6}$ The Emeryville station was out of service from May 2012 through late January 2013; therefore no fuel was dispensed into the buses during that time. The downtime was explained in a previous report.
} 


\section{Evaluation Results}

The results presented in this section focus on data from January 2016 through December 2016. During that data period, the FCEBs operated 447,720 miles over 52,102 hours of fuel cell operation. This indicates an overall operational speed of $8.6 \mathrm{mph}$. The analysis results presented in this section include the overall fleet. The diesel baseline buses include ten Gillig buses in operation at AC Transit.

\section{Route Assignments}

During the data period presented here, four buses operated from AC Transit's Emeryville Division and nine buses operated from the Oakland Division. AC Transit operates the FCEBs on most routes out of Emeryville, with the exception of any commuter routes such as Transbay service. The buses at the Oakland Division are also randomly dispatched on any of the local routes serviced by 40 -foot buses.

The Emeryville Division has 21 local routes that are served by 40 -foot buses and the Oakland Division has 17 routes. Table 2 provides a summary of the weekday local routes that the FCEBs could be operated on at each of the divisions. The data include deadhead as well as in-service time. The average speed at each of the two depots is similar at around $10 \mathrm{mph}$. The ZEBA buses are also operated on these routes during weekends.

Table 2. Daily Summary of Local Routes for AC Transit Buses

\begin{tabular}{|l|c|c|c|c|c|}
\hline Division & Routes & Blocks & $\begin{array}{c}\text { Time } \\
(\mathbf{h})\end{array}$ & $\begin{array}{c}\text { Distance } \\
(\mathbf{m i})\end{array}$ & $\begin{array}{c}\text { Average } \\
\text { Speed } \\
(\mathbf{m p h})\end{array}$ \\
\hline Emeryville & 21 & 133 & $1,776.8$ & 17,643 & 9.93 \\
\hline Oakland & 17 & 113 & $1,380.5$ & 13,786 & 9.98 \\
\hline
\end{tabular}

\section{Bus Use and Availability}

Bus use and availability are indicators of reliability. Lower bus usage may indicate downtime for maintenance or purposeful reduction of planned work for the buses. This section summarizes bus usage and availability for the FCEBs and baseline buses.

The first measure of reliability is bus use, which is measured by tracking accumulated bus mileage. Table 3 summarizes average monthly mileage for the ZEBA buses during the data period. Currently, the average monthly operating mileage for the FCEBs is 2,870 miles. This represents a $15 \%$ increase to the monthly average of 2,492 miles reported for the FCEBs during the previous data period (January 2015-December 2015). The current average for the FCEBs is $34 \%$ lower than the monthly average for the Gillig diesel buses (4,360 miles). Figure 8 shows the average monthly mileage trends for the FCEBs and diesel buses during the data period. The monthly mileage for the FCEBs was consistently higher than 2,600 miles per month. Six of the individual ZEBA buses have achieved a monthly average above the target of 3,000 miles per month during this data period. The fleet-wide monthly average for all ZEBA buses has surpassed the 3,000 miles per month target for four months during this data period. 
Table 3. Average Monthly Mileage (Report Data Period)

\begin{tabular}{|c|c|c|c|c|}
\hline Bus & $\begin{array}{c}\text { Ending } \\
\text { Hubodometer }\end{array}$ & $\begin{array}{c}\text { Total } \\
\text { Mileage }\end{array}$ & Months & $\begin{array}{c}\text { Average } \\
\text { Monthly } \\
\text { Mileage }\end{array}$ \\
\hline FC4 & 148,984 & 37,804 & 12 & 3,150 \\
\hline FC5 & 151,333 & 34,106 & 12 & 2,842 \\
\hline FC6 & 122,378 & 31,121 & 12 & 2,593 \\
\hline FC7 & 135,291 & 18,056 & 12 & 1,505 \\
\hline FC8 & 83,810 & 25,308 & 12 & 2,109 \\
\hline FC9 & 118,514 & 40,490 & 12 & 3,374 \\
\hline FC10 & 157,378 & 42,605 & 12 & 3,550 \\
\hline FC11 & 150,197 & 41,241 & 12 & 3,437 \\
\hline FC12 & 166,021 & 41,104 & 12 & 3,425 \\
\hline FC13 & 80,964 & 31,271 & 12 & 2,606 \\
\hline FC14 & 168,135 & 35,704 & 12 & 2,975 \\
\hline FC15 & 133,846 & 30,431 & 12 & 2,536 \\
\hline FC16 & 158,000 & 38,479 & 12 & 3,207 \\
\hline Total FCEB & & $\mathbf{4 4 7 , 7 2 0}$ & $\mathbf{1 5 6}$ & $\mathbf{2 , 8 7 0}$ \\
\hline 1338 & 196,602 & 50,757 & 12 & 4,230 \\
\hline 1339 & 200,002 & 49,306 & 12 & 4,109 \\
\hline 1340 & 210,188 & 56,760 & 12 & 4,730 \\
\hline 1341 & 195,091 & 56,118 & 12 & 4,677 \\
\hline 1342 & 200,805 & 47,768 & 12 & 3,981 \\
\hline 1343 & 198,202 & 54,015 & 12 & 4,501 \\
\hline 1344 & 182,407 & 42,540 & 12 & 3,545 \\
\hline 1345 & 201,651 & 55,832 & 12 & 4,653 \\
\hline 1346 & 196,026 & 55,406 & 12 & 4,617 \\
\hline 1347 & 187,391 & 54,718 & 12 & 4,560 \\
\hline Total Gillig Diesel & & $\mathbf{5 2 3 , 2 2 0}$ & $\mathbf{1 2 0}$ & $\mathbf{4 , 3 6 0}$ \\
\hline & & & & \\
\hline
\end{tabular}




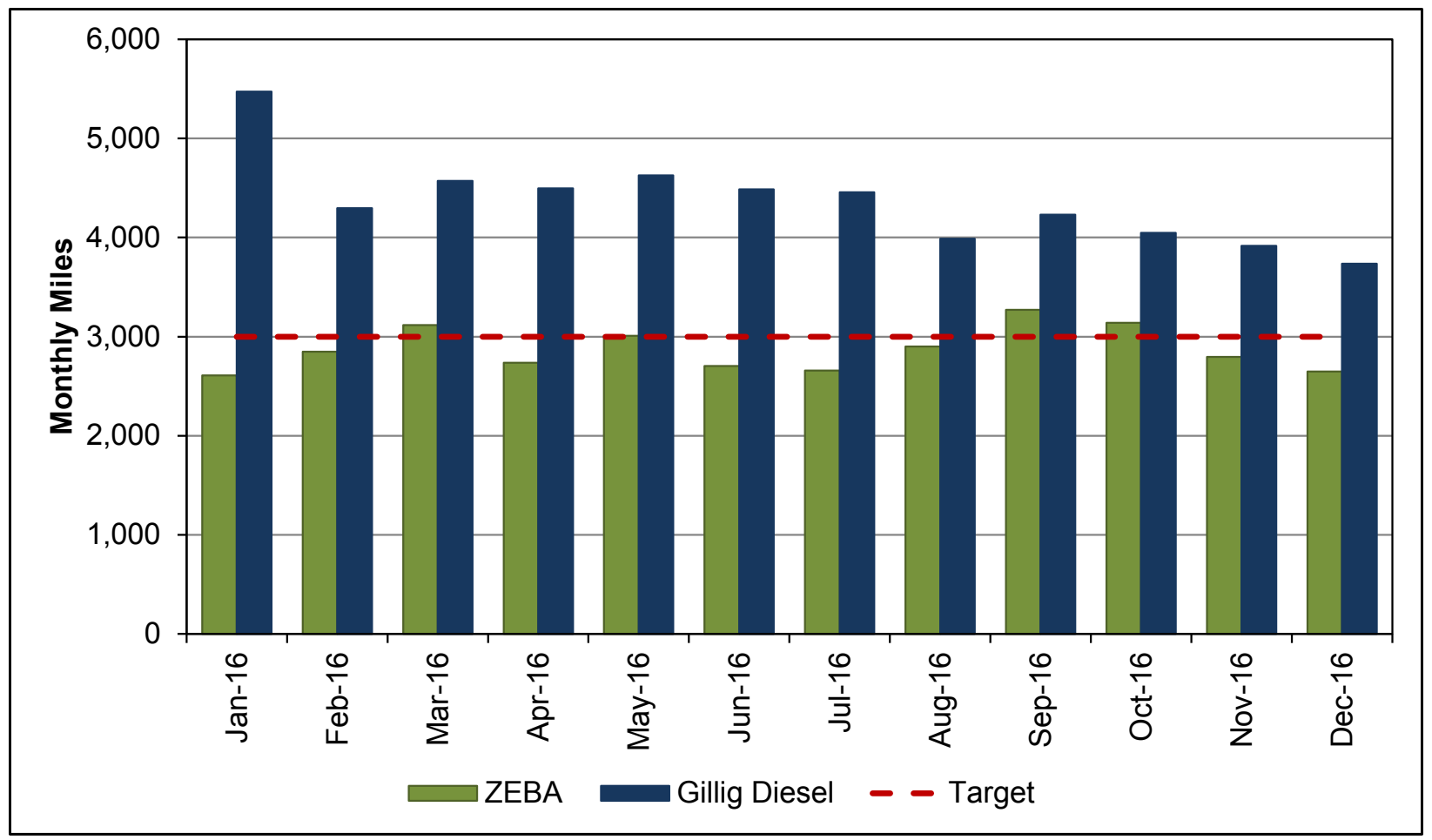

Figure 8. Monthly average miles for the ZEBA FCEBs and Gillig diesel buses

Another measure of reliability is bus availability - the number of days the buses are actually available for service at the time of morning pull-out compared to the number days that the buses are planned for operation, expressed as percent availability. AC Transit plans to operate its buses in service every day, although the diesel buses operate on weekends more frequently than the ZEBA FCEBs do. Table 4 shows the availability numbers for each of the 13 ZEBA buses during the data period. The availability for the individual ZEBA buses ranged from a low of $51 \%$ to a high of $94 \%$. The overall average availability for the fleet is $80 \%$. The buses with the lowest availability (FC7 and FC8) were out of service approximately 50\% of the time. FC7 was unavailable primarily for fuel cell power plant (FCPP) issues that proved difficult to troubleshoot. At the end of the data period, the bus was out for body repair. FC8 experienced issues with the fuel cell system, hybrid system, and general air system. These issues are explained further in the section "Summary of Achievements and Challenges". 
Table 4. Summary of ZEBA FCEB Availability by Bus (Report Data Period)

\begin{tabular}{|c|c|c|c|}
\hline Bus & $\begin{array}{c}\text { Planned } \\
\text { Days }\end{array}$ & $\begin{array}{c}\text { Available } \\
\text { Days }\end{array}$ & $\begin{array}{c}\text { Percent } \\
\text { Availability }\end{array}$ \\
\hline FC4 & 366 & 322 & $88 \%$ \\
\hline FC5 & 366 & 274 & $75 \%$ \\
\hline FC6 & 366 & 278 & $76 \%$ \\
\hline FC7 & 366 & 185 & $51 \%$ \\
\hline FC8 & 366 & 200 & $55 \%$ \\
\hline FC9 & 366 & 329 & $90 \%$ \\
\hline FC10 & 366 & 343 & $94 \%$ \\
\hline FC11 & 366 & 341 & $93 \%$ \\
\hline FC12 & 366 & 315 & $86 \%$ \\
\hline FC13 & 366 & 289 & $79 \%$ \\
\hline FC14 & 366 & 328 & $90 \%$ \\
\hline FC15 & 366 & 255 & $70 \%$ \\
\hline FC16 & 366 & 330 & $90 \%$ \\
\hline Total FCEB & $\mathbf{4 , 7 5 8}$ & $\mathbf{3 , 7 8 9}$ & $\mathbf{8 0 \%}$ \\
\hline
\end{tabular}

Figure 9 shows monthly availability for the ZEBA FCEBs (green line) and the Gillig diesel buses (dark blue line) for the data period. The monthly average availability varied between $73 \%$ and $86 \%$ for the FCEBs and between $81 \%$ and $98 \%$ for the diesel buses. The availability of the FCPP is also included on the graph (light green line).

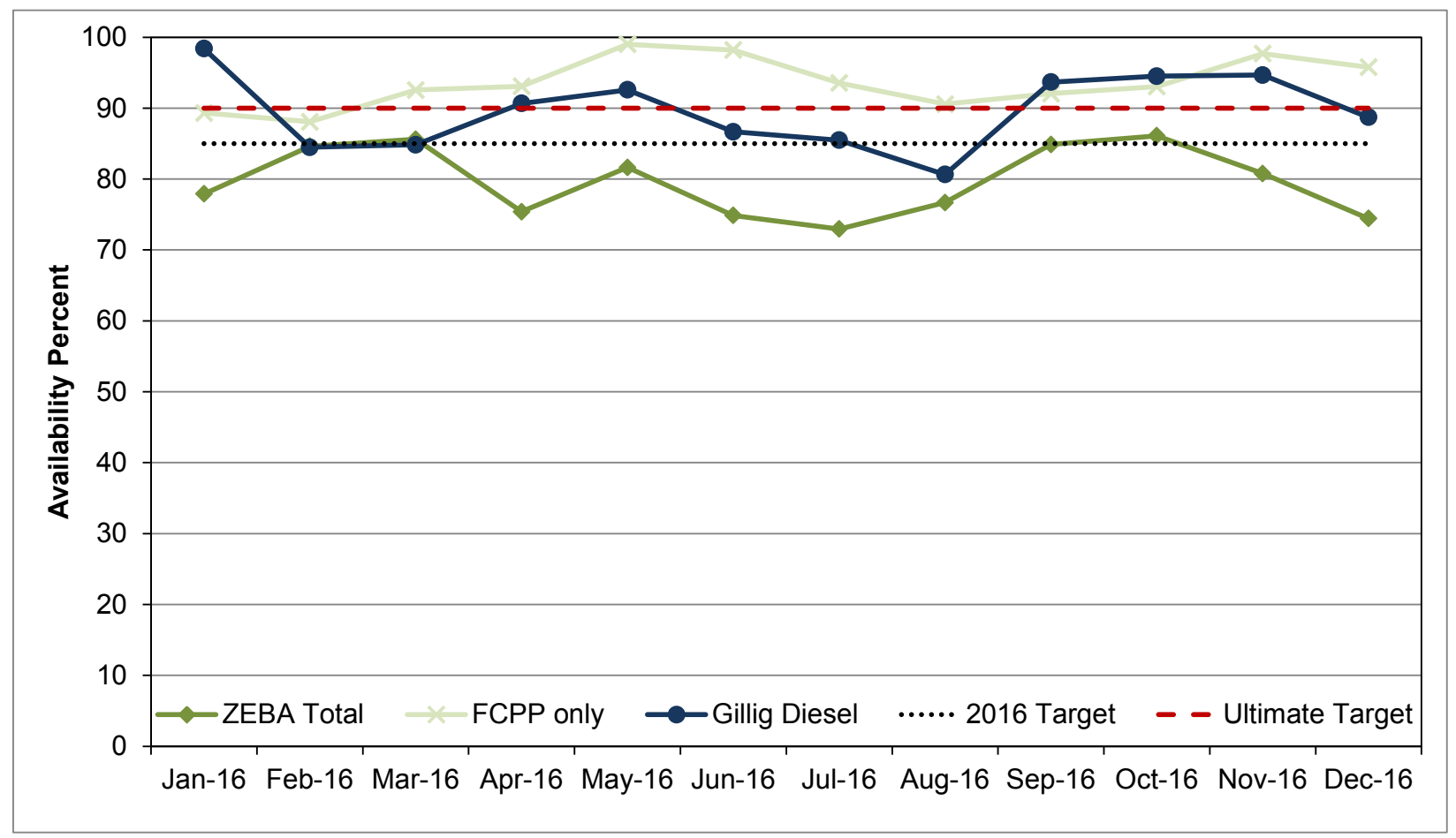

Figure 9. Availability for the ZEBA FCEBs and diesel buses 
The reasons for unavailability for the FCEBs and diesel buses are summarized in Table 5. During the data period, the average availability for the FCEB fleet was $80 \%$. The Gillig diesel buses had an overall availability of $90 \%$. Bus-related maintenance (separate from the fuel cell, hybrid, and traction battery systems) is the reason for the highest percentage of unavailability for the ZEBA buses, followed by fuel-cell-related issues. For the Gillig buses, the majority of their unavailability was due to similar bus-related issues. The data contained in Table 5 are also shown graphically in Figure 10 and Figure 11.

Table 5. Summary of Availability and Unavailability of Buses for Service (Report Data Period)

\begin{tabular}{|l|c|c|c|c|}
\hline \multicolumn{1}{|c|}{ Category } & $\begin{array}{c}\text { FCEB } \\
\text { \# Days }\end{array}$ & $\begin{array}{c}\text { FCEB } \\
\%\end{array}$ & $\begin{array}{c}\text { Gillig } \\
\text { Diesel } \\
\text { \# Days }\end{array}$ & $\begin{array}{c}\text { Gillig } \\
\text { Diesel } \\
\%\end{array}$ \\
\hline Planned work days & 4,758 & & 3,660 & \\
\hline Bus availability & 3,789 & $\mathbf{8 0} \%$ & 3,259 & $90 \%$ \\
\hline Bus unavailability & $\mathbf{9 6 9}$ & $\mathbf{2 0 \%}$ & $\mathbf{3 8 0}$ & $\mathbf{1 0 \%}$ \\
\hline Power plant (fuel cell/engine) & 305 & $6.4 \%$ & 134 & $3.0 \%$ \\
\hline Hybrid propulsion & 205 & $4.3 \%$ & & - \\
\hline Traction batteries & 25 & $0.5 \%$ & & - \\
\hline General bus issues & 315 & $6.6 \%$ & 169 & $4.7 \%$ \\
\hline Preventive maintenance (PM) & 119 & $2.5 \%$ & 2 & $0.5 \%$ \\
\hline Transmission & - & - & 90 & $2.1 \%$ \\
\hline HVAC & - & - & 6 & $0.1 \%$ \\
\hline
\end{tabular}

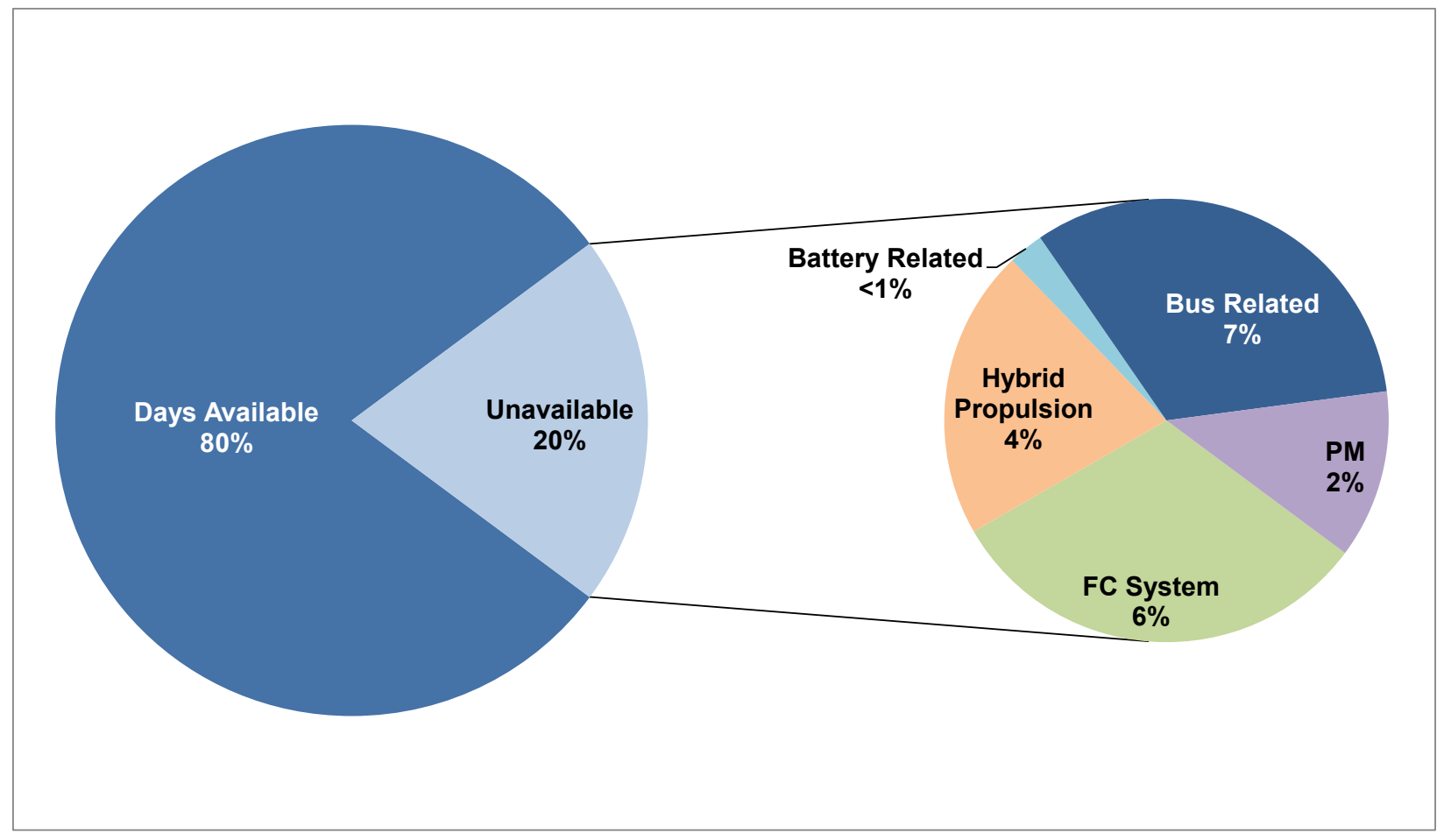

Figure 10. Availability and unavailability by category for the FCEB fleet 


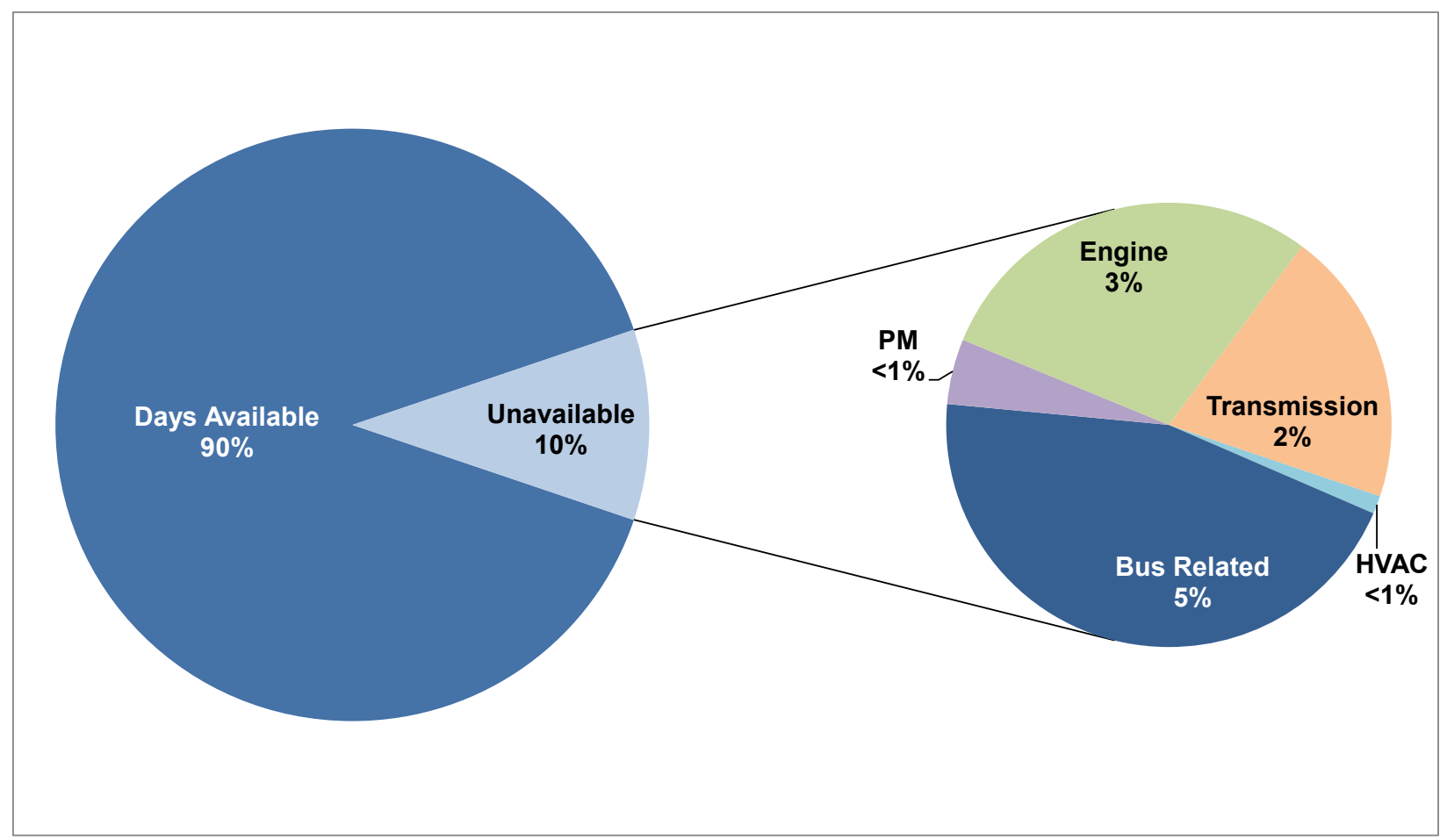

Figure 11. Availability and unavailability by category for the Gillig diesel fleet

\section{Fuel Economy and Cost}

As discussed previously, hydrogen fuel is provided by two fueling stations designed and constructed by Linde. For both stations, hydrogen is dispensed at up to 350 bar (5,000 psi). AC Transit employees perform all fueling services for the FCEBs. NREL collects fueling records from three sources: electronic records from AC Transit's Fleet Watch system, electronic fueling records from Linde, and manual logs from AC Transit. NREL merges these records for the analysis.

Table 6 shows hydrogen and diesel fuel consumption and fuel economy for the study buses over the data period. The FCEBs had an overall average fuel economy of 5.42 miles per kilogram of hydrogen, which equates to 6.12 miles per diesel gallon equivalent (dge). The energy conversion from kilograms of hydrogen to dge appears at the end of Appendix B. (Appendices B through $G$ contain summary statistics for the FCEBs and diesel buses.) The diesel buses average 4.12 miles per dge. These results indicate that the FCEBs have an average fuel economy that is $45 \%$ higher than that of the Gillig diesel buses. 
Table 6. Fuel Use and Economy (Report Data Period)

\begin{tabular}{|c|c|c|c|c|c|}
\hline Bus & $\begin{array}{c}\text { Mileage } \\
\text { (fuel base) }\end{array}$ & $\begin{array}{c}\text { Hydrogen } \\
(\mathbf{k g})\end{array}$ & $\begin{array}{c}\text { Miles per } \\
\mathbf{k g}\end{array}$ & $\begin{array}{c}\text { Diesel } \\
\text { (dge) }\end{array}$ & $\begin{array}{c}\text { Miles per } \\
\text { dge }\end{array}$ \\
\hline FC4 & 32,016 & 5,598 & 5.72 & 4,954 & 6.46 \\
\hline FC5 & 32,602 & 5,786 & 5.63 & 5,121 & 6.37 \\
\hline FC6 & 30,056 & 6,409 & 4.69 & 5,671 & 5.30 \\
\hline FC7 & 16,582 & 3,477 & 4.77 & 3,077 & 5.39 \\
\hline FC8 & 24,518 & 5,014 & 4.89 & 4,437 & 5.53 \\
\hline FC9 & 35,881 & 6,339 & 5.66 & 5,610 & 6.40 \\
\hline FC10 & 39,436 & 7,011 & 5.62 & 6,205 & 6.36 \\
\hline FC11 & 37,014 & 7,403 & 5.00 & 6,551 & 5.65 \\
\hline FC12 & 38,610 & 6,641 & 5.81 & 5,877 & 7.07 \\
\hline FC13 & 29,496 & 5,265 & 5.60 & 4,660 & 6.33 \\
\hline FC14 & 34,449 & 6,416 & 6.01 & 5,678 & 6.07 \\
\hline FC15 & 28,734 & 5,200 & 5.53 & 4,601 & 6.24 \\
\hline FC16 & 37,268 & 6,373 & 5.85 & 5,639 & 6.61 \\
\hline FCEB Total & $\mathbf{4 1 6 , 6 6 2}$ & $\mathbf{7 6 , 9 3 2}$ & $\mathbf{5 . 4 2}$ & $\mathbf{6 8 , 0 8 1}$ & $\mathbf{6 . 1 2}$ \\
\hline 1338 & 49,790 & & & 11,507 & 4.33 \\
\hline 1339 & 48,847 & & & 12,154 & 4.02 \\
\hline 1340 & 54,496 & & & 12,431 & 4.38 \\
\hline 1341 & 55,710 & & & 13,117 & 4.25 \\
\hline 1342 & 46,532 & & & 10,615 & 4.38 \\
\hline 1343 & 53,038 & & & 12,982 & 4.09 \\
\hline 1344 & 42,473 & & & 10,805 & 3.93 \\
\hline 1345 & 54,172 & & & 12,391 & 4.37 \\
\hline 1346 & 53,694 & & & 12,567 & 4.27 \\
\hline 1347 & 53,516 & & 121,568 & 4.12 \\
\hline Gillig Diesel Total & $\mathbf{5 1 2 , 2 6 8}$ & & & & $\mathbf{4 . 2 1}$ \\
\hline
\end{tabular}

Figure 12 shows monthly average fuel economy for the FCEBs and diesel buses in miles per dge. The average monthly high temperature is included in the graph to track any seasonal variations in the fuel economy due to heating or cooling of the buses, which might require additional energy use. NREL uses data from weather stations monitored by the National Oceanic and Atmospheric Administration (NOAA). ${ }^{7}$ For the ZEBA demonstration, NREL uses temperature data from the Oakland Airport weather station.

\footnotetext{
${ }^{7}$ NOAA Quality Controlled local climatological data website: http://www.ncdc.noaa.gov/qclcd/QCLCD?prior=N.
} 


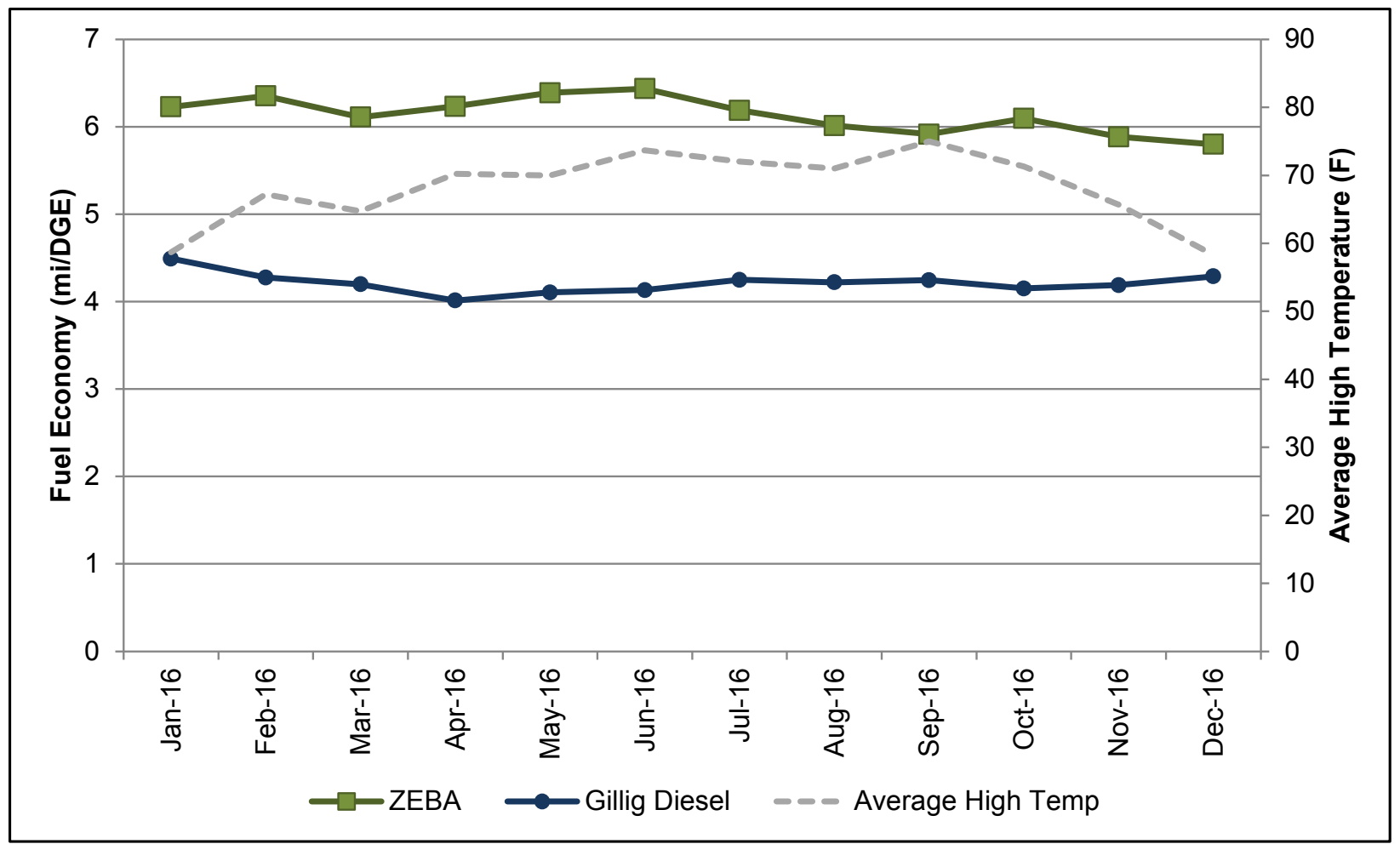

Figure 12. Average fuel economy for the ZEBA FCEBs and diesel buses (report data period)

Table 7 provides the summary of fuel costs for the FCEBs and diesel baseline buses for the data period. The cost of hydrogen production as dispensed during this period was $\$ 7.03$ per kilogram, not including the capital cost of the station. The hydrogen fuel cost per mile calculates to $\$ 1.30$. Diesel fuel cost during the reporting period was $\$ 1.55$ per gallon, which calculates to $\$ 0.37$ per mile for the Gillig diesel buses. The costs provided in this report reflect AC Transit's experience, which may not be the same as that of other agencies. Fuel costs for transit agencies depend on negotiated agreements between fuel providers and can vary widely based on a number of factors such as fuel source and station design.

Table 7. Summary of Fuel Cost for FCEBs and Diesel Buses (Report Data Period)

\begin{tabular}{|l|c|c|}
\hline & FCEB & Gillig Diesel \\
\hline Cost per unit (kg or gal) & $\$ 7.03$ & $\$ 1.55$ \\
\hline Total miles (fuel base) & 416,662 & 512,268 \\
\hline Total fuel (kg or gal) & 766,932 & 121,568 \\
\hline Fuel cost (\$) & $\$ 540,975$ & $\$ 188,307$ \\
\hline Fuel cost per mile (\$) & $\$ 1.30$ & $\$ 0.37$ \\
\hline
\end{tabular}




\section{Roadcall Analysis}

A roadcall or revenue vehicle system failure is defined as a failure of an in-service bus that causes the bus to be replaced on route or causes a significant delay in schedule. ${ }^{8}$ If the problem with the bus can be repaired during a layover and the schedule is kept, this is not considered a roadcall. The analysis described here includes only roadcalls that were caused by "chargeable" failures. Chargeable roadcalls include systems that can physically disable the bus from operating on route, such as interlocks (doors, air system), engine, or things that are deemed to be safety issues if operation of the bus continues. They do not include roadcalls for things such as problems with radios, fareboxes, or destination signs.

The transit industry measures reliability as mean distance between failures, also documented as miles between roadcalls (MBRC). Table 8 provides the MBRC for the FCEBs and diesel buses categorized by bus roadcalls and propulsion-related roadcalls. Propulsion-related roadcalls include all roadcalls due to propulsion-related systems including the fuel cell system (or engine for a conventional bus), electric drive, fuel, exhaust, air intake, cooling, non-lighting electrical, and transmission systems. The fuel-cell-system-related roadcalls and MBRC are included for the FCEBs. The fuel cell system MBRC includes any roadcalls due to issues with the fuel cell stack or associated balance of plant. Figure 13 presents the cumulative MBRC by category for the FCEBs and diesel baseline buses. The bus MBRC for the ZEBA FCEBs continues to increase over time and has surpassed the DOE/FTA ultimate target of 4,000 miles. The fuel cell system MBRC has increased over time and surpassed the ultimate target of 20,000 miles in early 2015.

Table 8. Roadcalls and MBRC (Cumulative)

\begin{tabular}{|l|c|c|}
\hline & ZEBA FCEB & Gillig Diesel \\
\hline Dates & $9 / 11-12 / 16$ & $6 / 13-12 / 16$ \\
\hline Mileage & $1,657,171$ & $1,913,952$ \\
\hline Average miles & 136,527 & 196,837 \\
\hline Bus roadcalls & 352 & 287 \\
\hline Bus MBRC & 4,708 & 6,669 \\
\hline Propulsion roadcalls & 199 & 142 \\
\hline Propulsion MBRC & 8,327 & 13,479 \\
\hline Fuel cell system roadcalls & 77 & $\mathrm{~N} / \mathrm{A}$ \\
\hline Fuel cell system MBRC & 21,522 & $\mathrm{~N} / \mathrm{A}$ \\
\hline
\end{tabular}

${ }^{8}$ AC Transit defines a significant delay as 6 or more minutes. 


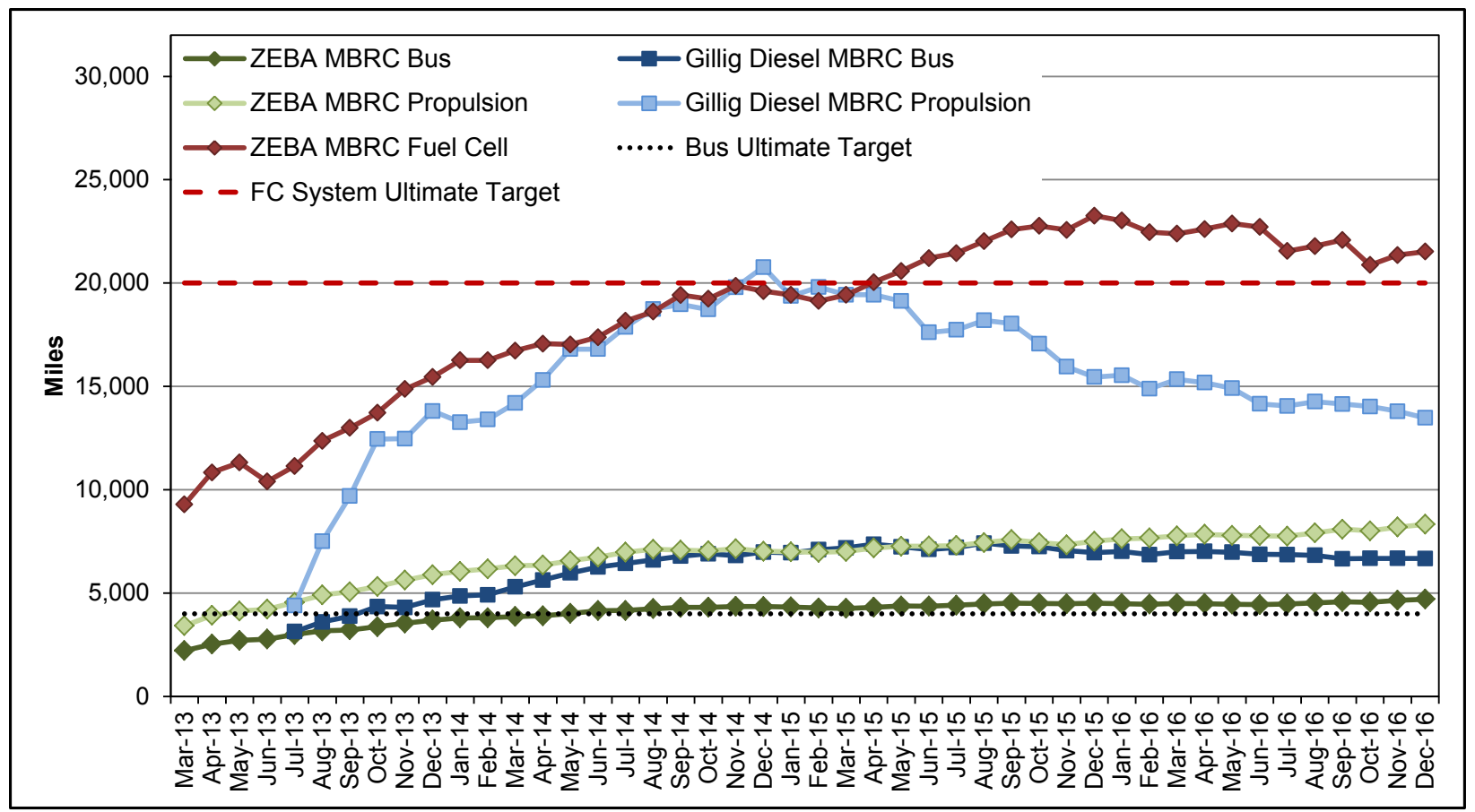

Figure 13. Cumulative MBRC for the FCEBs and diesel buses

\section{Maintenance Analysis}

The maintenance cost analysis in this section is only for the data period. Warranty costs are generally not included in the cost-per-mile calculations. NREL collected and analyzed all work orders for the study buses for this evaluation. For consistency with other evaluations, NREL set the maintenance labor rate at $\$ 50$ per hour, which does not reflect an average rate for AC Transit. The analysis eliminates costs for accident-related repair, which are extremely variable from bus to bus. This section first covers total maintenance costs and then maintenance costs by bus system. The ZEBA FCEBs are now beyond the term for the original warranty. As mentioned previously, AC Transit has entered into extended support agreements with US Hybrid and EnerDel. A grant from FTA as part of the National Fuel Cell Bus Program funded the cost of these agreements. The cost for the agreements is outlined in the summary costs at the end of this section. AC Transit has one maintenance trainer assigned to support maintenance activities with the FCEBs and provide maintenance training for mechanics and other AC Transit staff. By the start of 2015, AC Transit had transitioned all regular maintenance tasks to its staff. The manufacturers provide support as needed with any issues that are encountered with the buses.

\section{Total Work Order Maintenance Costs}

Total maintenance costs include the price of parts and labor rates at \$50 per hour. NREL calculates the cost per mile as follows:

$$
\text { Cost per mile }=[(\text { labor hours } * 50)+\text { parts cost }] / \text { mileage }
$$

Table 9 shows total maintenance costs for the FCEBs and diesel buses. The table separates scheduled and unscheduled maintenance cost per mile by bus and by fleet. 
Table 9. Total Work Order Maintenance Costs (Report Data Period)

\begin{tabular}{|c|c|c|c|c|c|c|}
\hline Bus & Mileage & Parts (\$) & $\begin{array}{l}\text { Labor } \\
\text { Hours }\end{array}$ & $\begin{array}{l}\text { Total } \\
\text { Cost per } \\
\text { Mile (\$) }\end{array}$ & $\begin{array}{l}\text { Scheduled } \\
\text { Cost per } \\
\text { Mile (\$) }\end{array}$ & $\begin{array}{l}\text { Unscheduled } \\
\text { Cost per } \\
\text { Mile (\$) }\end{array}$ \\
\hline FC4 & 37,804 & 6,865 & 506.7 & 0.85 & 0.31 & 0.54 \\
\hline FC5 & 34,106 & 5,557 & 523.6 & 0.93 & 0.31 & 0.62 \\
\hline FC6 & 31,121 & 1,948 & 353.7 & 0.63 & 0.26 & 0.37 \\
\hline FC7 & 18,056 & 7,641 & 740.7 & 2.47 & 0.41 & 2.06 \\
\hline FC8 & 25,308 & 37,070 & 526.8 & 2.51 & 0.21 & 2.30 \\
\hline FC9 & 40,490 & 18,884 & 532.1 & 1.12 & 0.18 & 0.94 \\
\hline FC10 & 42,605 & 11,463 & 460.0 & 0.81 & 0.23 & 0.58 \\
\hline FC11 & 41,241 & 16,075 & 377.3 & 0.85 & 0.20 & 0.65 \\
\hline FC12 & 41,104 & 5,043 & 375.2 & 0.58 & 0.23 & 0.35 \\
\hline FC13 & 31,271 & 13,930 & 516.1 & 1.27 & 0.21 & 1.06 \\
\hline FC14 & 35,704 & 29,410 & 398.5 & 1.38 & 0.24 & 1.14 \\
\hline FC15 & 30,431 & 11,498 & 548.6 & 1.28 & 0.33 & 0.95 \\
\hline FC16 & 38,479 & 15,896 & 455.9 & 1.01 & 0.31 & 0.70 \\
\hline Total FCEB & 447,720 & 181,280 & 6,315 & 1.11 & 0.26 & 0.85 \\
\hline 1338 & 50,757 & 17,621 & 484.7 & 0.82 & 0.17 & 0.65 \\
\hline 1339 & 49,306 & 8,302 & 362.0 & 0.54 & 0.16 & 0.39 \\
\hline 1340 & 56,760 & 14,031 & 420.2 & 0.62 & 0.13 & 0.47 \\
\hline 1341 & 56,118 & 10,832 & 370.1 & 0.52 & 0.13 & 0.37 \\
\hline 1342 & 47,768 & 12,131 & 402.7 & 0.68 & 0.15 & 0.54 \\
\hline 1343 & 54,015 & 10,675 & 335.2 & 0.51 & 0.14 & 0.37 \\
\hline 1344 & 42,540 & 8,955 & 332.0 & 0.60 & 0.16 & 0.44 \\
\hline 1345 & 55,832 & 7,534 & 331.2 & 0.43 & 0.13 & 0.29 \\
\hline 1346 & 55,406 & 6,784 & 286.7 & 0.38 & 0.15 & 0.24 \\
\hline 1347 & 54,718 & 9,264 & 373.1 & 0.51 & 0.15 & 0.35 \\
\hline Total Gillig Diesel & 523,220 & 106,129 & 3,698 & 0.56 & 0.15 & 0.41 \\
\hline
\end{tabular}

Figure 14 shows the monthly scheduled and unscheduled cost per mile for the ZEBA FCEBs and Gillig diesel buses. The average monthly odometer for each fleet is included on the figure. Issues with the ZEBA FCEBs resulted in higher costs for several months during the data period. The high cost for many of the FCEB parts was the primary factor for the increases. High-cost parts include air compressor converters, bus air compressor, coolant pump, and air dryers. Some of these high-cost parts are part of the bus systems and not the electric propulsion system. AC Transit reports that the FCEBs have several bus system components that are not common with the diesel buses of the same model. Those FCEB components are more costly than that of the diesel buses. The costs for the Gillig diesel buses were consistent over the data period. 


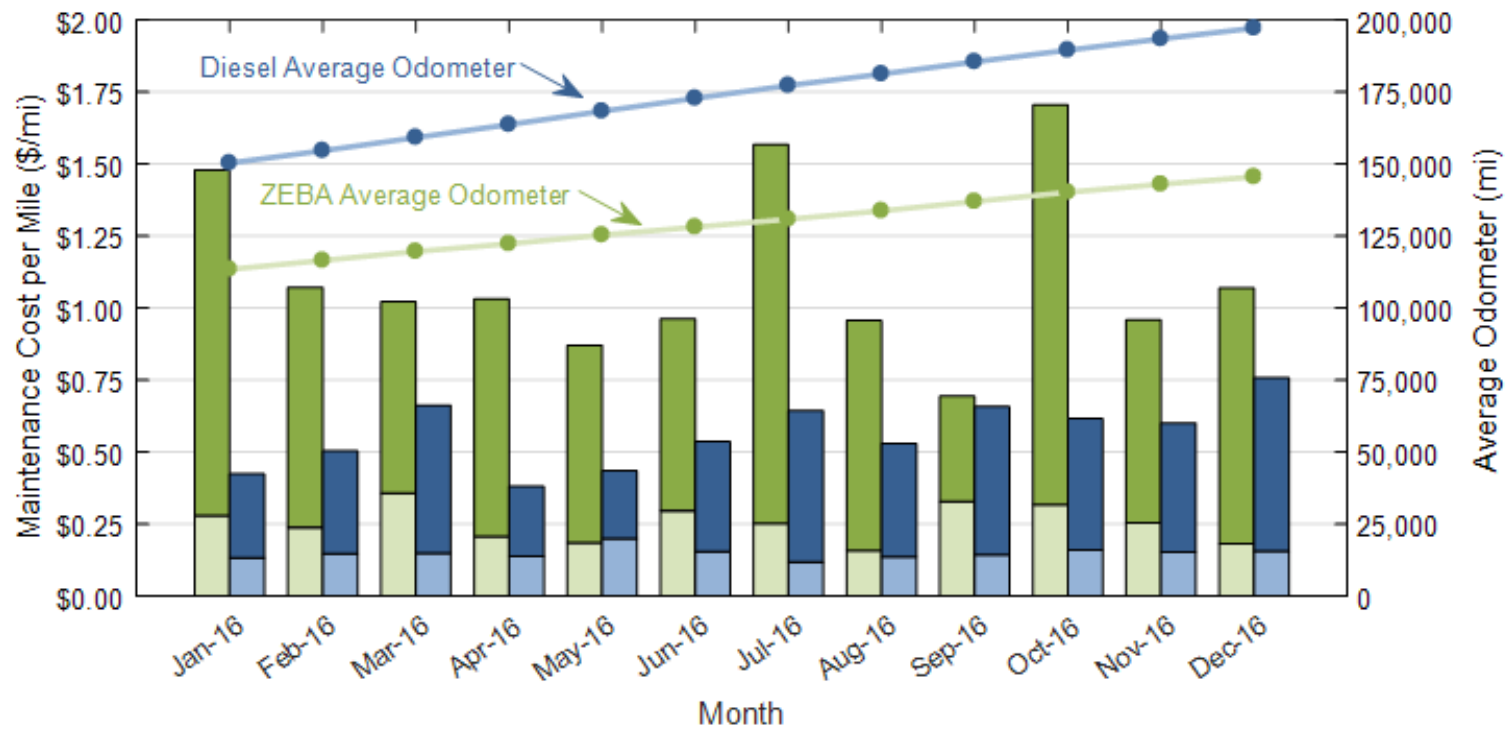

ZEBA Scheduled $\square$ ZEBA Unscheduled $\square$ Diesel Scheduled $\square$ Diesel Unscheduled

Figure 14. Monthly scheduled and unscheduled costs per mile for the ZEBA FCEBs and diesel buses (report data period)

\section{Work Order Maintenance Costs Categorized by System}

Table 10 shows maintenance costs by vehicle system and bus study group (without warranty costs). The vehicle systems shown in the table are as follows:

- Cab, body, and accessories: Includes body, glass, and paint repairs following accidents; cab and sheet metal repairs on seats and doors; and accessory repairs such as hubodometers and radios

- Propulsion-related systems: Repairs for exhaust, fuel, engine, electric motors, fuel cell modules, propulsion control, non-lighting electrical (charging, cranking, and ignition), air intake, cooling, and transmission

- Preventive maintenance inspections (PMI): Labor for inspections during preventive maintenance

- Brakes

- Frame, steering, and suspension

- Heating, ventilation, and air conditioning (HVAC)

- Lighting

- Air system, general

- Axles, wheels, and drive shaft

- Tires. 
Table 10. Work Order Maintenance Cost per Mile by System (Report Data Period)

\begin{tabular}{|l|c|c|c|c|}
\hline \multicolumn{1}{|c|}{ System } & $\begin{array}{c}\text { ZEBA } \\
\text { FCEB } \\
\text { Cost per } \\
\text { Mile (\$) }\end{array}$ & $\begin{array}{c}\text { ZEBA } \\
\text { FCEB } \\
\text { Percent } \\
\text { of Total } \\
(\%)\end{array}$ & $\begin{array}{c}\text { Gillig } \\
\text { Diesel } \\
\text { Cost } \\
\text { per } \\
\text { Mile (\$) }\end{array}$ & $\begin{array}{c}\text { Gillig } \\
\text { Diesel } \\
\text { Percent } \\
\text { of Total } \\
(\%)\end{array}$ \\
\hline Propulsion-related & 0.38 & 34 & 0.16 & 28 \\
\hline Cab, body, and accessories & 0.21 & 19 & 0.14 & 25 \\
\hline PMI & 0.19 & 17 & 0.08 & 14 \\
\hline Brakes & 0.02 & 2 & 0.07 & 12 \\
\hline Frame, steering, and suspension & 0.03 & 3 & 0.02 & 3 \\
\hline HVAC & 0.04 & 4 & 0.01 & 3 \\
\hline Lighting & 0.01 & 1 & 0.01 & 2 \\
\hline General air system repairs & 0.22 & 20 & 0.06 & 11 \\
\hline Axles, wheels, and drive shaft & 0.02 & 1 & 0.00 & 1 \\
\hline Tires & 0.00 & 0 & 0.00 & 0 \\
\hline Total & $\mathbf{1 . 1 1}$ & 100 & $\mathbf{0 . 5 6}$ & 100 \\
\hline
\end{tabular}

The systems with the highest percentage of maintenance costs for the FCEBs were propulsionrelated; general air system; and cab, body, and accessories. The Gillig diesel bus systems with the highest percentage of maintenance costs were propulsion-related; cab, body, and accessories; and PMI. Figure 15 shows the monthly cost per mile by system for the ZEBA FCEBs. High parts costs are the primary reason for the higher cost per mile during January, July, and October. Another factor is the added labor hours for troubleshooting issues and for training. As the agency ramps up training outside the original group of mechanics, labor hours can be double or triple depending on the number of maintenance staff being trained. Figure 16 shows the monthly cost per mile by system for the Gillig diesel buses. Appendix D provides additional graphs showing the monthly labor hours and maintenance costs by system for the ZEBA FCEBs and Appendix G provides monthly maintenance graphs for the diesel buses. 


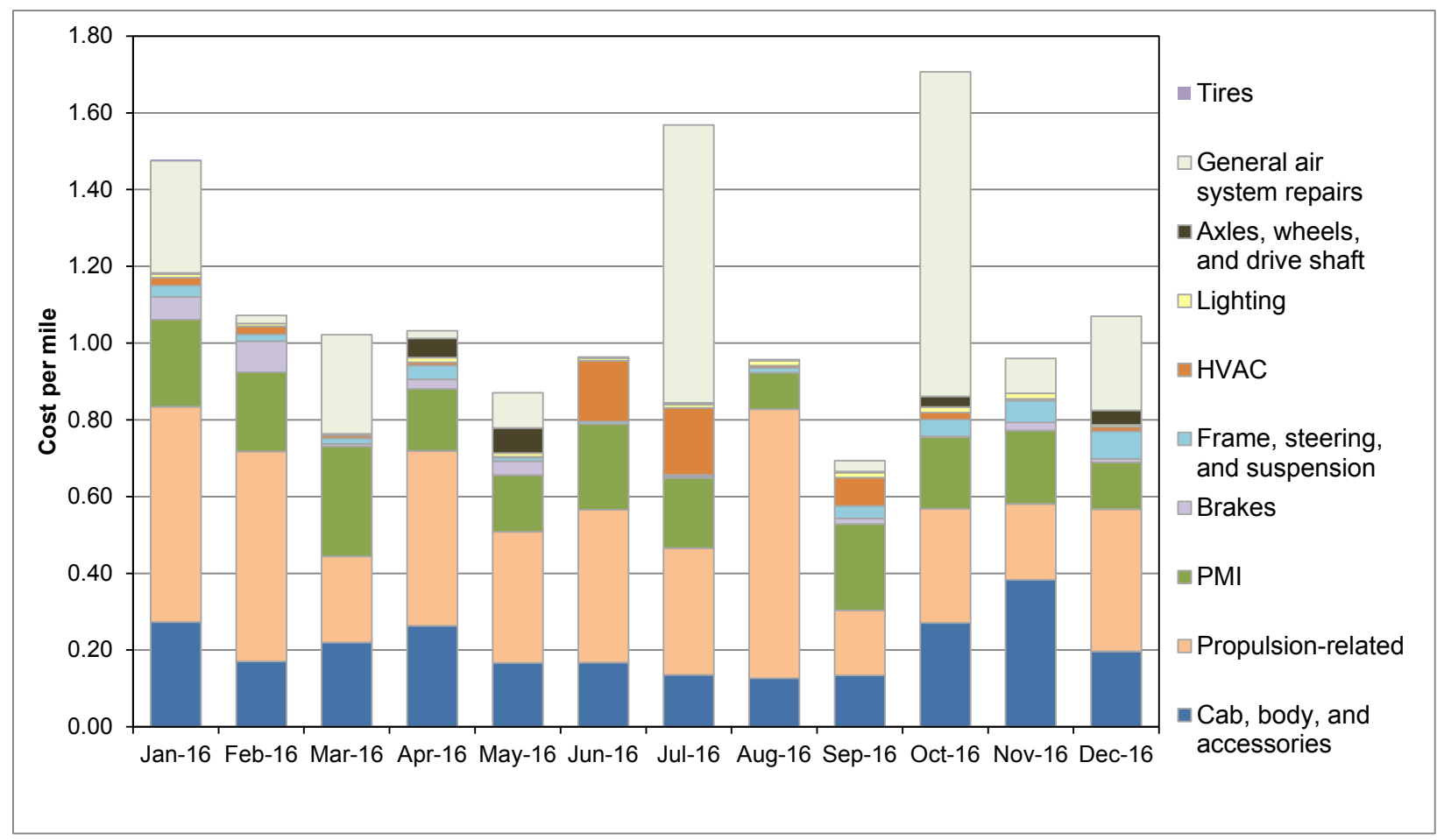

Figure 15. Monthly cost per mile by category for the ZEBA FCEBs (report data period)

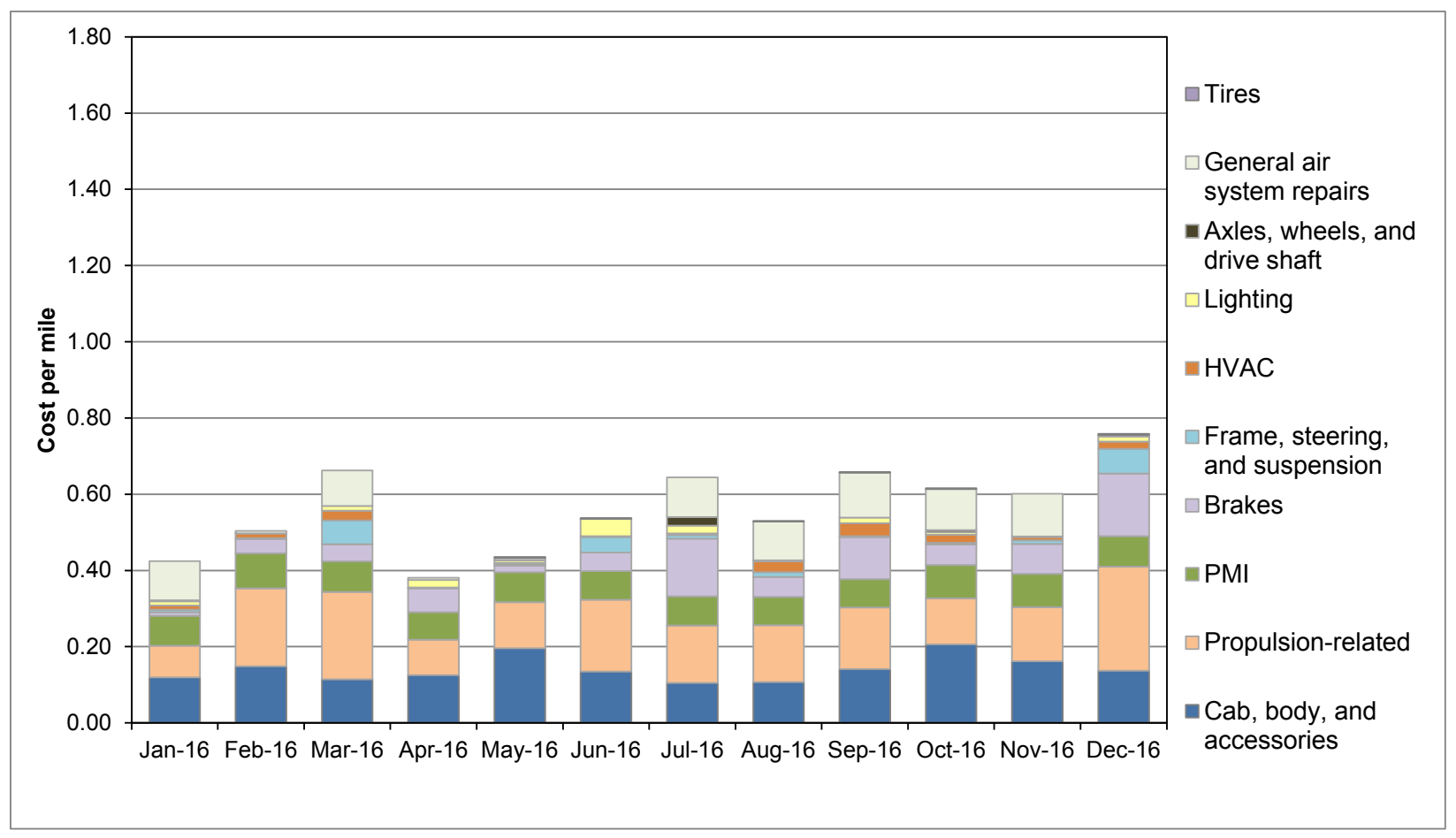

Figure 16. Monthly cost per mile by category for the Gillig diesel buses (report data period) 
Brake wear analysis-Electric drive buses are expected to have lower brake maintenance costs compared to conventional buses because they employ regenerative braking. In a regenerative braking system, braking causes the electric motor to reverse the direction of rotation, which captures the energy and helps slow the bus. Other aspects that affect brake wear are bus weight and duty cycle. Heavier buses would be expected to have higher brake wear. Lower-speed routes that have more stop and go would also result in higher brake wear. Table 11 provides a comparison of the factors affecting brake life for the FCEBs and diesel buses.

Table 11. Comparison of Factors Affecting Brake Life

\begin{tabular}{|l|c|c|}
\hline \multicolumn{1}{|c|}{ Factor } & ZEBA FCEB & Gillig Diesel \\
\hline Braking system & Regenerative & Retarder \\
\hline Weight (GWWR) & 39,350 & 39,600 \\
\hline Average speed & $10 \mathrm{mph}$ & $10 \mathrm{mph}$ \\
\hline Brake type & Front and rear disk & Front disk, rear drum \\
\hline
\end{tabular}

The diesel buses have a retarder, which will help slow the bus. Because the gross vehicle weight rating (GVWR) of the FCEBs is similar to that of the Gillig diesel buses, that aspect is not a significant factor. The duty cycle of the buses is also similar at an average speed of $10 \mathrm{mph}$, although AC Transit reports that the diesel buses are often operated on commuter routes with higher speeds and less stop and go. The primary difference between the ZEBA FCEBs and diesel buses is brake type - the FCEBs have all disk brakes and the diesel buses have rear drum brakes.

Over the report data period, brake repairs for the ZEBA FCEBs accounted for only $\$ 0.02$ per mile compared to $\$ 0.07$ per mile for the diesel buses. The majority of ZEBA bus brake repairs in 2016 were not for brake relines - repairs to brake treadles and brake chambers accounted for the majority of cost (42\%). Only one ZEBA bus had a front brake reline during 2016, which added less than $\$ 0.01$ per mile to the cost.

Table 12 shows the brake reline comparison for the ZEBA FCEBs and diesel buses for the life of the buses. Since the ZEBA FCEBs were placed into service, only six have had relines, three of which were due to roadcalls for smoking brakes. (The roadcall relines are not included in the table.) For those roadcall-related repairs, the data do not indicate if the pads were worn below recommended thickness. One ZEBA bus had a reline at 59,000 miles that was due to defective brake materials. That reline was not counted as a first reline because the pads were at threefourths thickness. The highest-mileage bus that has not had a reline has surpassed 168,000 miles. For the diesel buses, $40 \%$ of the brake system cost was for relines. During 2016, the diesel buses had 12 relines - two for front brakes and the remainder for rear brakes. The average miles for a first reline on the diesel buses was 100,000 miles. Second relines on the buses occurred at an average odometer reading of 158,000 miles. All ten diesel buses have had at least two relines since they were placed in service. 
Table 12. Brake Reline Comparison for the ZEBA FCEBs and Diesel Buses

\begin{tabular}{|c|c|c|c|c|c|c|c|}
\hline \multirow{2}{*}{ Bus } & \multirow{2}{*}{$\begin{array}{l}\text { Current } \\
\text { Odometer }\end{array}$} & \multicolumn{3}{|c|}{$\overline{\text { First Reline }}$} & \multicolumn{3}{|c|}{ Second Reline } \\
\hline & & Date & Odometer & Reline Type & Date & Odometer & Reline Type \\
\hline FC4 & 148,984 & & & & & & \\
\hline FC5 & 151,333 & & & & & & \\
\hline FC6 & 122,378 & & & & & & \\
\hline FC7 & 135,291 & $12 / 3 / 2015$ & 127,779 & 2-wheel, Rear & & & \\
\hline FC8 & 83,810 & & & & & & \\
\hline FC9 & 118,514 & & & & & & \\
\hline FC10 & 157,378 & $9 / 1 / 2015$ & 114,936 & 2-wheel, Front & & & \\
\hline FC11 & 150,197 & $11 / 2 / 2016$ & 153,003 & 2-wheel, Front & & & \\
\hline FC12 & 166,021 & $12 / 24 / 2015$ & 124,661 & 2-wheel, Front & & & \\
\hline FC13 & 80,964 & & & & & & \\
\hline FC14 & 168,135 & & & & & & \\
\hline FC15 & 133,846 & & & & & & \\
\hline FC16 & 158,000 & & & & & & \\
\hline FCEB & \multicolumn{2}{|c|}{ Average First Reline } & 130,095 & \multicolumn{2}{|c|}{ Average Second Reline } & N/A & \\
\hline 1338 & 196,602 & $5 / 25 / 2015$ & 112,346 & 2-wheel, Rear & $4 / 10 / 2016$ & 164,071 & 2-wheel, Rear \\
\hline 1339 & 200,002 & $4 / 14 / 2015$ & 110,806 & 2-wheel, Rear & $8 / 6 / 2016$ & 182,046 & 2-wheel, Rear \\
\hline 1340 & 210,188 & $3 / 29 / 2015$ & 111,368 & 2-wheel, Front & $5 / 2 / 2015$ & 116,903 & 2-wheel, Rear \\
\hline 1341 & 195,091 & $1 / 23 / 2015$ & 98,914 & 2-wheel, Rear & 9/16/2015 & 119,130 & 2-wheel, Rear \\
\hline 1342 & 200,805 & $1 / 9 / 2015$ & 99,173 & 2-wheel, Rear & $8 / 23 / 2015$ & 132,161 & 2-wheel, Rear \\
\hline 1343 & 198,202 & $5 / 8 / 2015$ & 105,449 & 2-wheel, Rear & $9 / 13 / 2016$ & 183,376 & 2-wheel, Rear \\
\hline 1344 & 182,407 & $10 / 08 / 2014$ & 87,036 & 2-wheel, Rear & $3 / 13 / 2016$ & 151,400 & 2-wheel, Rear \\
\hline 1345 & 201,651 & $6 / 17 / 2014$ & 62,903 & 2-wheel, Rear & $11 / 11 / 2015$ & 138,813 & 2-wheel, Rear \\
\hline 1346 & 196,026 & $5 / 4 / 2015$ & 104,369 & 2-wheel, Rear & 9/16/2016 & 181,471 & 2-wheel, Rear \\
\hline 1347 & 187,391 & $5 / 26 / 2015$ & 95,248 & 2-wheel, Rear & $7 / 28 / 2016$ & 166,765 & 2-wheel, Rear \\
\hline Diesel & \multicolumn{2}{|c|}{ Average First Reline } & 98,761 & \multicolumn{2}{|c|}{ Average Second Reline } & 153,614 & \\
\hline
\end{tabular}

\section{Propulsion-Related Work Order Maintenance Costs}

Propulsion-related vehicle systems include the exhaust, fuel, engine, electric propulsion, air intake, cooling, non-lighting electrical, and transmission systems. These systems have been separated to highlight maintenance costs most directly affected by the advanced propulsion system changes for the buses. Table 13 shows the propulsion-related system maintenance by category for the FCEBs and diesel buses during the data period. Parts for scheduled maintenance, such as filters and fluids, are included in the specific system categories. For example, oil and oil filters are included in the engine subsystem parts costs, while air filters are included in the air subsystem parts costs. Appendix D and Appendix G provide figures showing the monthly labor and maintenance costs for the propulsion systems by subcategory.

- Total propulsion-related-When compared to the Gillig diesel buses, the FCEBs' propulsion-related maintenance costs were 2.4 times higher.

- Exhaust system - Costs for this system were low for the FCEBs. The diesel buses had significant exhaust system repairs, accounting for $37 \%$ of the total propulsion system costs. Issues included replacing NOx sensors, turbochargers, and a muffler. 
- Fuel system-Costs for this system for the FCEBs and diesel buses were low.

- Power plant and electric propulsion-For the FCEBs, the electric propulsion system accounted for the majority of costs at $33 \%$ of the total propulsion system costs, followed by fuel cell power plant repairs at $29 \%$. Power plant (engine) repairs made up $18 \%$ of the total propulsion system costs for the diesel buses; there are no electric propulsion costs for the diesel buses because they are not hybrids.

- Non-lighting electrical (charging, cranking, and ignition)—Costs for this system for the study bus groups were low.

- Air intake-Costs for this system for the study bus groups were low.

- Cooling-Costs for this system accounted for $17 \%$ of the FCEB costs and $14 \%$ of the diesel bus costs. The FCEBs had costs primarily for maintenance of the fuel cell and hybrid cooling systems. The high costs for parts, such as cooling pumps, had a significant impact on the overall cooling system costs.

- Transmission-Costs for this system for the diesel buses were low. The FCEBs do not have a traditional transmission; costs are included in the electric propulsion category.

- Hydraulic-Costs for this system for the study bus groups were low or zero. 
Table 13. Propulsion-Related Work Order Maintenance Costs by System (Report Data Period)

\begin{tabular}{|c|c|c|c|}
\hline Maintenance System & Maintenance System Costs & $\begin{array}{l}\text { ZEBA } \\
\text { FCEB }\end{array}$ & $\begin{array}{l}\text { Gillig } \\
\text { Diesel }\end{array}$ \\
\hline Mileage & Mileage & 447,720 & 523,220 \\
\hline \multirow{4}{*}{$\begin{array}{l}\text { Total Propulsion-Related } \\
\text { Systems } \\
\text { (Roll-up of all systems below) }\end{array}$} & Parts cost $(\$)$ & $54,664.71$ & $35,293.83$ \\
\hline & Labor hours & $2,287.2$ & 936.5 \\
\hline & Total cost $(\$)$ & $169,024.71$ & $82,118.33$ \\
\hline & Total cost (\$) per mile & 0.38 & 0.16 \\
\hline \multirow{4}{*}{ Exhaust System Repairs } & Parts cost (\$) & 122.47 & $17,027.53$ \\
\hline & Labor hours & 56.5 & 269.6 \\
\hline & Total cost $(\$)$ & $2,947.47$ & $30,508.53$ \\
\hline & Total cost (\$) per mile & 0.01 & 0.06 \\
\hline \multirow{4}{*}{ Fuel System Repairs } & Parts cost $(\$)$ & $3,093.62$ & $3,002.96$ \\
\hline & Labor hours & 156.5 & 47 \\
\hline & Total cost (\$) & $10,918.62$ & $5,352.96$ \\
\hline & Total cost (\$) per mile & 0.02 & 0.01 \\
\hline \multirow{4}{*}{ Power Plant System Repairs } & Parts cost $(\$)$ & $2,798.13$ & $3,265.31$ \\
\hline & Labor hours & 910.0 & 231.37 \\
\hline & Total cost $(\$)$ & $48,297.13$ & $14,833.81$ \\
\hline & Total cost (\$) per mile & 0.11 & 0.03 \\
\hline \multirow{4}{*}{$\begin{array}{l}\text { Electric Propulsion System } \\
\text { Repairs }\end{array}$} & Parts cost (\$) & $20,741.55$ & 0.00 \\
\hline & Labor hours & 709.6 & 0.0 \\
\hline & Total cost (\$) & $56,223.55$ & 0.00 \\
\hline & Total cost (\$) per mile & 0.13 & 0.00 \\
\hline \multirow{4}{*}{$\begin{array}{l}\text { Non-Lighting Electrical System } \\
\text { Repairs (General Electrical, } \\
\text { Charging, Cranking, Ignition) }\end{array}$} & Parts cost $(\$)$ & $3,731.66$ & $4,013.26$ \\
\hline & Labor hours & 201.3 & 135.91 \\
\hline & Total cost (\$) & $13,794.16$ & $10,808.76$ \\
\hline & Total cost (\$) per mile & 0.03 & 0.02 \\
\hline \multirow{4}{*}{ Air Intake System Repairs } & Parts cost $(\$)$ & $7,138.60$ & $4,007.26$ \\
\hline & Labor hours & 4.0 & 38.38 \\
\hline & Total cost $(\$)$ & $7,338.60$ & $5,926.26$ \\
\hline & Total cost (\$) per mile & 0.02 & 0.01 \\
\hline \multirow{4}{*}{ Cooling System Repairs } & Parts cost $(\$)$ & $17,038.68$ & $4,007.26$ \\
\hline & Labor hours & 249.3 & 155.79 \\
\hline & Total cost (\$) & $29,505.18$ & $11,796.76$ \\
\hline & Total cost $(\$)$ per mile & 0.07 & 0.02 \\
\hline \multirow{4}{*}{ Transmission System Repairs } & Parts cost $(\$)$ & 0.00 & 523.10 \\
\hline & Labor hours & 0.0 & 54.42 \\
\hline & Total cost (\$) & 0.00 & $3,244.10$ \\
\hline & Total cost (\$) per mile & 0.00 & 0.01 \\
\hline \multirow{4}{*}{ Hydraulic System Repairs } & Parts cost $(\$)$ & 0.00 & 679.01 \\
\hline & Labor hours & 0.00 & 4.00 \\
\hline & Total cost $(\$)$ & 0.00 & 879.01 \\
\hline & Total cost (\$) per mile & 0.00 & 0.00 \\
\hline
\end{tabular}




\section{Total Project Costs}

Throughout the demonstration, the ZEBA FCEBs have incurred some costs that fall outside of the typical maintenance costs reported above. These costs were not included in the analysis presented in the previous maintenance cost sections. Activities included research and training, shuttling the FCEBs between depots, and fueling and cleaning. These costs are considered nonrecurring costs for the FCEBs; however, they add to the current cost per mile of the FCEBs. NREL reported on these costs in detail in the previous reports. The non-recurring costs for the ZEBA fleet have dropped dramatically over time. During the data period, the added cost was primarily for shuttling FCEBs between depots, which added $\$ 0.04$ per mile to the costs. Because Emeryville does not have a maintenance bay equipped to allow work on a hydrogen-fueled bus, AC Transit staff have to shuttle the buses to the Oakland depot where there is a maintenance bay outfitted for the FCEBs. Once the Emeryville maintenance bay is completed, these costs should be eliminated. For a fair comparison, NREL also removed the costs for shuttling the diesel buses from the analysis.

Costs for AC Transit's extended support agreements with US Hybrid and EnerDel began in April 2014. While the FTA grant covers the cost for these agreements, other interested agencies should understand the potential costs for FCEBs outside of the initial warranty period. Table 14 summarizes the total costs for the FCEBs and diesel baseline buses including the extra labor and extended support during the data period. The cost for shuttling the diesel buses between depots adds less than $\$ 0.01$ to the total cost per mile.

Table 14. Total Maintenance Cost per Mile Including Extra Labor and Extended Support (Report Data Period)

\begin{tabular}{|l|r|r|}
\hline & \multicolumn{1}{|c|}{$\begin{array}{c}\text { ZEBA } \\
\text { FCEB }\end{array}$} & \multicolumn{1}{c|}{$\begin{array}{c}\text { Gillig } \\
\text { Diesel }\end{array}$} \\
\hline Maintenance labor hours & 6,315 & 3,698 \\
\hline Extra labor hours & 417 & 32 \\
\hline Total labor hours & 6,732 & 3,730 \\
\hline Total parts cost & $\$ 181,280$ & $\$ 106,129$ \\
\hline Extended warranty cost & $\$ 501,353$ & - \\
\hline Total cost per mile & $\$ 2.28$ & $\$ 0.56$ \\
\hline
\end{tabular}




\section{Summary of Achievements and Challenges}

This section describes the most recent experience with the ZEBA buses at AC Transit. Since the last report, there have been multiple accomplishments.

- The thirteen buses have operated 1,657,171 miles and accumulated 204,163 hours on the fuel cell power systems since being placed into service.

- AC Transit has safely fueled its FCEBs 3,428 times with more than 76,932 kg of hydrogen during the data period.

- The fleet leading FCPP has surpassed 23,000 hours on the fuel cell power system and is estimated to reach the ultimate target of 25,000 hours in 2017.

- The FCEBs have experienced less brake wear compared to the conventional diesel buses. Only five out of the thirteen FCEBs have had brake relines since being placed in service. The highest-mileage bus that has not had a reline has surpassed 160,000 miles. The FCEBs are hybrids and benefit from regenerative braking.

- Working with technology partners and implementing the lessons learned from more than 15 years of experience, AC Transit staff developed a training curriculum and has provided training to more than 217 mechanics, which totals to more than 7,392 hours of training specifically on zero-emission bus technology.

\section{Progress Toward Meeting Technical Targets}

DOE and FTA published performance and cost targets for FCEBs. These targets, established with industry input, include interim targets for 2016 and ultimate targets for commercialization. Table 15 summarizes the current performance results of the ZEBA buses compared to these targets. The results in the table cover the data period from September 2011 through December 2016.

Increasing the durability and reliability of the fuel cell system to meet transit requirements continues to be a key challenge. FTA life cycle requirements for a full size transit bus are 12 years or 500,000 miles. Because transit agencies typically rebuild the diesel engines at approximately mid-life, an FCPP should be able to operate for at least half the life of the bus. DOE and FTA have set an early performance target of 4-6 years (or 20,000-30,000 hours) durability for the fuel cell propulsion system. The ZEBA buses continue to demonstrate some of the highest hours for FCEBs in service. As mentioned in previous reports, three of the FCPPs in the ZEBA buses had accumulated hours in service prior to being installed in the new buses. Those three FCPPs continue to operate and accumulate hours in service. 
Table 15. Summary of FCEB Performance Compared to DOE/FTA Targets ${ }^{9}$

\begin{tabular}{|c|c|c|c|c|}
\hline & Units & This Report ${ }^{\mathrm{a}}$ & $\begin{array}{l}2016 \\
\text { Target }\end{array}$ & $\begin{array}{l}\text { Ultimate } \\
\text { Target }\end{array}$ \\
\hline Bus lifetime & years/miles & $\begin{array}{c}6.4 / \\
39,600-167,400^{b}\end{array}$ & $12 / 500,000$ & $12 / 500,000$ \\
\hline Power plant lifetime ${ }^{c}$ & hours & $7,200-23,400^{d}$ & 18,000 & 25,000 \\
\hline Bus availability & $\%$ & 74 & 85 & 90 \\
\hline Fuel fills ${ }^{\mathrm{e}}$ & per day & 1 & $1(<10 \mathrm{~min})$ & $1(<10 \mathrm{~min})$ \\
\hline Bus cost $^{f}$ & $\$$ & $2,500,000^{g}$ & $1,000,000$ & 600,000 \\
\hline $\begin{array}{l}\text { Roadcall frequency } \\
\text { (bus/fuel cell system) }\end{array}$ & $\begin{array}{l}\text { miles between } \\
\text { roadcalls }\end{array}$ & $\begin{array}{l}4,700 / \\
21,500\end{array}$ & $\begin{array}{l}3,500 / \\
15,000\end{array}$ & $\begin{array}{l}4,000 / \\
20,000\end{array}$ \\
\hline Operation time & $\begin{array}{l}\text { hours per day/ } \\
\text { days per week }\end{array}$ & $\begin{array}{c}7-14 / \\
5-7\end{array}$ & $20 / 7$ & $20 / 7$ \\
\hline $\begin{array}{l}\text { Scheduled and } \\
\text { unscheduled } \\
\text { maintenance cost }\end{array}$ & \$/mile & 1.11 & 0.75 & 0.40 \\
\hline Range & miles & $250^{i}$ & 300 & 300 \\
\hline Fuel economy & $\begin{array}{l}\text { miles per diesel } \\
\text { gallon equivalent }\end{array}$ & 6.65 & 8 & 8 \\
\hline
\end{tabular}

${ }^{a}$ Summary of the results for the ZEBA buses in this report: data from September 2011 to December 2016.

${ }^{\mathrm{b}}$ Accumulated totals for the ZEBA buses through December 2016; these buses have not reached end of life; targets are for lifetime.

${ }^{\mathrm{c}}$ For the DOE/FTA targets, the power plant is defined as the fuel cell system and the battery system. The fuel cell system includes supporting subsystems such as the air, fuel, coolant, and control subsystems. Power electronics, electric drive, and hydrogen storage tanks are excluded.

${ }^{\mathrm{d}}$ The status for power plant hours is for the fuel cell system only; battery lifetime hours were not available.

${ }^{\mathrm{e}}$ Multiple sequential fuel fills should be possible without an increase in fill time.

${ }^{\mathrm{f}}$ Cost targets are projected to a production volume of 400 systems per year. This production volume is assumed for analysis purposes only and does not represent an anticipated level of sales.

${ }^{\mathrm{g}}$ This represents AC Transit's per-bus purchase price for the ZEBA buses in 2010. More recent orders for FCEBs show a cost of $\$ 1.2$ million.

${ }^{\mathrm{h}}$ Excludes mid-life overhaul of the power plant.

${ }^{\mathrm{i}}$ Based on fuel economy and useful fuel tank capacity. AC Transit reports lower real-world range.

Figure 17 shows the cumulative hours on each FCPP through December 2016. The top FCPP has now achieved more than 23,000 hours of operation without major repair or cell replacements. This is the highest number of FCPP hours documented for an FCEB; it surpasses the 2016 target and moves the technology further toward meeting the ultimate target of 25,000 hours. All of the FCPPs have surpassed 14,000 hours of operation with the exception of FC13 that joined the AC Transit fleet in October 2015. Table 16 provides the total hours accumulated on each of the FCPPs since they were installed. The table includes the hours for the spare FCPPs as well as the 13 original FCPPs.

\footnotetext{
${ }^{9}$ Fuel Cell Technologies Program Record \# 12012, September 12, 2012, http://www.hydrogen.energy.gov/pdfs/12012 fuel cell bus targets.pdf.
} 


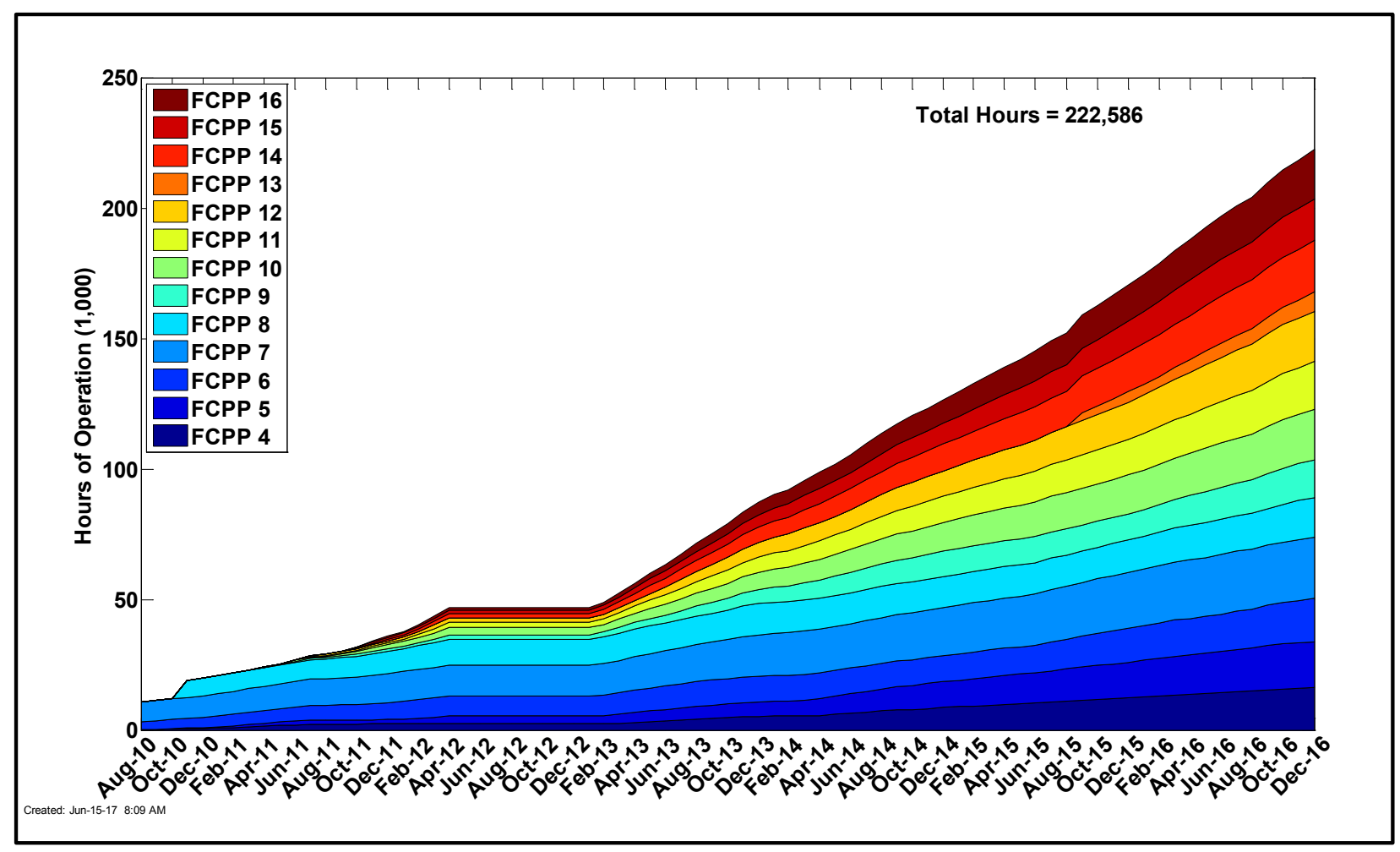

Figure 17. Cumulative FCPP hours on the ZEBA buses

Table 16. Total Hours Accumulated on the FCPPs

\begin{tabular}{|c|c|c|c|c|}
\hline FCPP & $\begin{array}{c}\text { Date of FCPP } \\
\text { Installation }\end{array}$ & $\begin{array}{c}\text { FCPP Hours } \\
\text { at Installation }\end{array}$ & $\begin{array}{c}\text { Total Hours } \\
\text { through } \\
\text { December 2015 }\end{array}$ & $\begin{array}{c}\text { Total Hours } \\
\text { through } \\
\text { December 2016 }\end{array}$ \\
\hline 4 & $8 / 22 / 10$ & 59 & 12,259 & 16,428 \\
\hline 5 & $8 / 20 / 10$ & 20 & 13,710 & 17,417 \\
\hline 6 & $8 / 1 / 10$ & 2,915 & 12,927 & 16,493 \\
\hline 7 & $8 / 29 / 10$ & 7,727 & 21,422 & 23,423 \\
\hline 8 & $11 / 15 / 10$ & 6,806 & 12,467 & 15,241 \\
\hline 9 & $2 / 22 / 11$ & 34 & 10,084 & 14,550 \\
\hline 10 & $3 / 1 / 11$ & 20 & 14,836 & 19,269 \\
\hline 11 & $5 / 5 / 11$ & 0 & 13,770 & 18,399 \\
\hline 12 & $5 / 12 / 11$ & 0 & 14,140 & 19,361 \\
\hline $13^{\text {a }}$ & $10 / 1 / 15$ & 0 & 4,099 & 7,285 \\
\hline 14 & $8 / 17 / 11$ & 0 & 15,091 & 19,793 \\
\hline 15 & $8 / 15 / 11$ & 0 & 11,843 & 15,996 \\
\hline 16 & $9 / 30 / 11$ & 0 & 13,868 & 18,991 \\
\hline
\end{tabular}

${ }^{a}$ Bus was acquired from Connecticut Transit and put into service in October 2015 with hours already on the FCPP. 


\section{Summary of Challenges}

Advanced technology demonstrations typically experience challenges and issues that need to be resolved. This section provides a few of the issues and the status of resolution.

Transition of maintenance to transit staff-The transition of knowledge from the manufacturers to the transit staff is essential to commercializing the technology. AC Transit continues to train increasing numbers of technicians to maintain the ZEBA buses. AC Transit has assigned a dedicated supervisor and mechanic at each depot to lead the work on the FCEBs. These employees handle the training and bring in other staff as needed. Much of the hands-on training is performed on an as-needed basis when FCEBs need to have repairs done. Any manufacturer support can be provided through remote diagnosis. The agency continues to experience challenges with troubleshooting new issues with the buses. This can be labor intensive and the downtime lowers availability for the fleet. Work orders can have multiple mechanics logging hours when several may have been in training. In this case, the time and cost of the repair will be artificially high. This added labor cost typically increases after the transit staff takes over maintenance work but drops over time as the staff becomes more familiar with the technology. This is also the case for scheduled preventive maintenance. AC Transit reports that a minor PM for the buses takes approximately 3 hours and a major PM is estimated at 8 hours. Over the data period, the agency has been training a number of staff in conducting scheduled maintenance tasks. In one case, labor for a single PM totaled 23 hours indicating a number of staff being trained. During 2016, AC Transit conducted 81 major PMs and 80 minor PMs on the ZEBA buses (approximately 6 of each per bus). Had those PMs been accomplished at the estimated labor hours, the scheduled maintenance cost would have been $\$ 0.14$ per mile as opposed to $\$ 0.19$ per mile.

Extended manufacturer support - AC Transit funded extended support from the manufacturers through a \$1.8 million grant through the National Fuel Cell Bus Program. AC Transit negotiated agreements with US Hybrid and EnerDel and set up purchase orders with Siemens, Van Hool, and Luxfer for parts as needed. The time period for these agreements has now ended. AC Transit received authorization to continue using the funds for this support but will have to negotiate new agreements with the manufacturers. The maintenance totals in the report show the cost of this extended support.

Parts supply and cost - AC Transit continues to experience some issues with availability of bus components that have a long lead time for delivery. One reason for the lead time is the need to order foreign supplied parts through a distributor. AC Transit has addressed this by purchasing some parts to keep in stock. The agency is also working toward sourcing parts directly from the component manufacturer. In addition, parts costs have risen since the buses surpassed the warranty period as AC Transit took responsibility for purchasing parts that the manufacturer previously covered. In some cases, the parts are expensive, which has a significant effect on the cost per mile for the buses. Also contributing to higher parts costs, AC Transit's distributor only offered some components as kits. This added unnecessary cost for cases where only one part out of the kit was needed for repair. Working directly with the component manufacturer also helps address this issue. The industry could aid in cutting costs by standardizing bus related components within platforms. Shared components for bus models will increase manufacturing quantities and improve inventory availability. This could result in lower cost and reduced 
downtime. The industry should also develop a robust supply chain for advanced components for FCEBs (as well as other electric drive buses).

Air compressor issues-Multiple buses have had issues with the air compressor and converter for the bus air system. Unlike the diesel version, the compressor and converter for the FCEBs is a combined unit - when one part fails, the entire unit must be replaced. AC Transit believes the system is reaching end of life because it seems to be failing on all of the buses at the same time. The agency is tracking the odometers at failure to help anticipate the issue in the future. This will allow AC Transit to order long-lead-time parts early to reduce downtime.

Fuel cell blower issues - Most of the buses experienced issues with the intake pump that supplies air to the fuel cell. This pump is part of the balance of plant inside the fuel cell module. The vendor for the part was rebuilding the pumps; however, the rebuilt pumps were not lasting as long as new ones. To address the issue, AC Transit located another vendor for the part. The turnaround time is longer, but the part is higher quality and works well.

Extended downtime-AC Transit has experienced issues with specific buses that resulted in extended downtime. During this data period, several buses were out of service for long periods for maintenance activities that are considered to be atypical.

- FC7 developed issues with the fuel cell system beginning in July, resulting in an overall availability of 51\% during 2016. Diagnosing the issue proved difficult, extending the downtime. AC Transit eventually traced the issue to the cooling system: several hoses were routed through areas that caused pinching and restricted flow. The fuel cell would shut down from overheating. Mechanics fixed the issue by rerouting hoses and changing out a pump.

- $\quad$ FC8 had several different issues over the data period that resulted in an overall availability of $55 \%$. One issue involved a damaged fuel cell air intake pump. It took time to get the part, which increased downtime. The compressor and converter for the air system also failed. AC transit initially replaced it with a rebuilt system. A new one was installed several months later. The bus also had issues with brake resistors and the HVAC system.

- FC15 was out of service for two months with drive system issues. A high voltage cable broke at the connection to the motor, causing an isolation fault and damaging the motor. AC Transit replaced the motor but was able to rebuild it to use as a spare. 


\section{Contacts}

DOE

1000 Independence Ave., SW

Washington, DC 20585

Jason Marcinkoski, Technology

Development Manager, Fuel Cell

Technologies Office

Phone: 202-586-7466

Email: jason.marcinkoski@,ee.doe.gov

NREL

15013 Denver West Parkway

Golden, CO 80401

Leslie Eudy, Senior Project Leader

Phone: 303-275-4412

Email: leslie.eudy@nrel.gov

\section{AC Transit}

1700 Franklin Street

Oakland, CA 94612

Salvador Llamas, Director of Maintenance Phone: 510-577-8803

Email: sllamas@actransit.org

\section{EnerDel Inc.}

15425 Herriman Blvd.

Noblesville, IN 46060

Tomasz Posnar, Vice President, Transportation and Aftermarket

Phone: 954-401-0338

Email: tomasz.poznar@enerdel.com

\section{Van Hool}

Bernard Van Hoolstraat 58

B-2500 Lier Koningshooikt, Belgium

Paul Jenné, Automotive Relations

Phone: +32 (3) 4202210

Email: paul.jenne@,vanhool.be

\section{Linde, LLC}

2389 Lincoln Avenue

Hayward, CA 94545

Nitin Natesan, Engineering Manager, Alternative Energy Projects

Phone: 510-786-5931

Email: nitin.natesan@lindeus.com 


\section{References and Related Reports}

All NREL hydrogen and fuel cell-related evaluation reports can be downloaded from the following website: https://www.nrel.gov/hydrogen/fuel-cell-bus-evaluation.html.

\section{AC Transit}

Eudy, L.; Post, M.; Jeffers, M. (2016). Zero Emission Bay Area (ZEBA) Fuel Cell Bus Demonstration Results: Fifth Report. NREL/TP-5400-66039. Golden, CO: National Renewable Energy Laboratory.

Eudy, L.; Post, M. (2015). Zero Emission Bay Area (ZEBA) Fuel Cell Bus Demonstration Results: Fourth Report. NREL/TP-5400-63719. Golden, CO: National Renewable Energy Laboratory.

Eudy, L.; Post, M. (2014). Zero Emission Bay Area (ZEBA) Fuel Cell Bus Demonstration Results: Third Report. NREL/TP-5400-60527. Golden, CO: National Renewable Energy Laboratory.

Eudy, L.; Chandler, K. (2012). Zero Emission Bay Area (ZEBA) Fuel Cell Bus Demonstration: Second Results Report. NREL/TP-5600-55367. Golden, CO: National Renewable Energy Laboratory.

Chandler, K.; Eudy, L. (2011). Zero Emission Bay Area (ZEBA) Fuel Cell Bus Demonstration: First Results Report. NREL/TP-5600-52015. Golden, CO: National Renewable Energy Laboratory.

\section{General}

Eudy, L.; Post, M.; Jeffers, M. (2016). Fuel Cell Buses in U.S. Transit Fleets: Current Status 2016. NREL/TP-5400-67097. Golden, CO: National Renewable Energy Laboratory.

Eudy, L.; Post, M.; Gikakis, C. (2015). Fuel Cell Buses in U.S. Transit Fleets: Current Status 2015. NREL/TP-5400-64974. Golden, CO: National Renewable Energy Laboratory.

Eudy, L.; Post, M.; Gikakis, C. (2014). Fuel Cell Buses in U.S. Transit Fleets: Current Status 2014. NREL/TP-5400-62683. Golden, CO: National Renewable Energy Laboratory.

Eudy, L.; Gikakis, C. (2013). Fuel Cell Buses in U.S. Transit Fleets: Current Status 2013. NREL/TP-5400-60490. Golden, CO: National Renewable Energy Laboratory.

Chandler, K.; Eudy, L. (2012). FTA Fuel Cell Bus Program: Research Accomplishments through 2011. FTA Report No. 0014. Washington, DC: Federal Transit Administration.

Eudy, L. (2010). Fuel Cell Transit Bus Evaluations, Joint Evaluation Plan for the U.S. Department of Energy and the Federal Transit Administration. NREL/TP-560-49342. Golden, CO: National Renewable Energy Laboratory. 


\section{Appendix A: TRL Guideline Table}

Technology Readiness Levels for FCEB Commercialization

\begin{tabular}{|c|c|c|c|}
\hline $\begin{array}{l}\text { Relative Level } \\
\text { of Technology } \\
\text { Development }\end{array}$ & $\begin{array}{l}\text { Technology } \\
\text { Readiness } \\
\text { Level }\end{array}$ & TRL Definition & Description \\
\hline Deployment & TRL 9 & $\begin{array}{l}\text { Actual system } \\
\text { operated over the full } \\
\text { range of expected } \\
\text { conditions }\end{array}$ & $\begin{array}{l}\text { The technology is in its final form. } \\
\text { Deployment, marketing, and support begin for } \\
\text { the first fully commercial products. }\end{array}$ \\
\hline \multirow{3}{*}{$\begin{array}{l}\text { Technology } \\
\text { Demonstration/ } \\
\text { Commissioning }\end{array}$} & TRL 8 & $\begin{array}{l}\text { Actual system } \\
\text { completed and } \\
\text { qualified through test } \\
\text { and demonstration }\end{array}$ & $\begin{array}{l}\text { The last step in true system development. } \\
\text { Demonstration of a limited production of } 50 \text { to } \\
100 \text { buses at a small number of locations. } \\
\text { Beginning the transition of all maintenance to } \\
\text { transit staff. }\end{array}$ \\
\hline & TRL 7 & $\begin{array}{l}\text { Full-scale validation in } \\
\text { relevant environment }\end{array}$ & $\begin{array}{l}\text { A major step up from TRL } 6 \text { by adding larger } \\
\text { numbers of buses and increasing the hours of } \\
\text { service. Full-scale demonstration and } \\
\text { reliability testing of } 5 \text { to } 10 \text { buses at several } \\
\text { locations. Manufacturers begin to train larger } \\
\text { numbers of transit staff in operation and } \\
\text { maintenance. }\end{array}$ \\
\hline & TRL 6 & $\begin{array}{l}\text { Engineering/pilot-scale } \\
\text { validation in relevant } \\
\text { environment }\end{array}$ & $\begin{array}{l}\text { First tests of prototype buses in actual transit } \\
\text { service. Field testing and design shakedown } \\
\text { of one to two prototypes. Manufacturers assist } \\
\text { in operation and typically handle all } \\
\text { maintenance. Begin to introduce transit staff to } \\
\text { technology. }\end{array}$ \\
\hline \multirow{2}{*}{$\begin{array}{l}\text { Technology } \\
\text { Development }\end{array}$} & TRL 5 & $\begin{array}{l}\text { Laboratory scale, } \\
\text { similar system } \\
\text { validation in relevant } \\
\text { environment }\end{array}$ & $\begin{array}{l}\text { Integrated system is tested in a laboratory } \\
\text { under simulated conditions based on early } \\
\text { modeling. System is integrated into an early } \\
\text { prototype or mule platform for some on-road } \\
\text { testing. }\end{array}$ \\
\hline & TRL 4 & $\begin{array}{l}\text { Component and } \\
\text { system validation in } \\
\text { laboratory environment }\end{array}$ & $\begin{array}{l}\text { Basic technological components are } \\
\text { integrated into the system and begin } \\
\text { laboratory testing and modeling of potential } \\
\text { duty cycles. }\end{array}$ \\
\hline \multirow[t]{2}{*}{$\begin{array}{l}\text { Research to } \\
\text { Prove } \\
\text { Feasibility }\end{array}$} & TRL 3 & $\begin{array}{l}\text { Analytical and } \\
\text { experimental critical } \\
\text { function and/or proof of } \\
\text { concept }\end{array}$ & $\begin{array}{l}\text { Active research into components and system } \\
\text { integration needs. Investigate what } \\
\text { requirements might be met with existing } \\
\text { commercial components. }\end{array}$ \\
\hline & \multirow{2}{*}{ TRL 2} & \multirow{2}{*}{$\begin{array}{l}\text { Technology concept } \\
\text { and/or application } \\
\text { formulated }\end{array}$} & \multirow{2}{*}{$\begin{array}{l}\text { Research technology needed to meet market } \\
\text { requirements. Define strategy for moving } \\
\text { through development stages. }\end{array}$} \\
\hline \multirow{2}{*}{$\begin{array}{l}\text { Basic } \\
\text { Technology } \\
\text { Research }\end{array}$} & & & \\
\hline & TRL 1 & $\begin{array}{l}\text { Basic principles } \\
\text { observed and reported }\end{array}$ & $\begin{array}{l}\text { Scientific research and early development of } \\
\text { FCEB concepts. }\end{array}$ \\
\hline
\end{tabular}




\section{Appendix B: ZEBA FCEB Fleet Summary Statistics}

\begin{tabular}{|c|c|c|c|c|}
\hline & $\begin{array}{c}\text { ZEBA } \\
9 / 11-4 / 12 \\
\text { (Early } \\
\text { Service) }\end{array}$ & $\begin{array}{c}\text { ZEBA } \\
5 / 12-2 / 13 \\
\text { (Station } \\
\text { Downtime } \\
\text { Period) }\end{array}$ & $\begin{array}{c}\text { ZEBA } \\
\text { 3/13-12/16 } \\
\text { (Data } \\
\text { Period) }\end{array}$ & $\begin{array}{c}\text { ZEBA } \\
\text { 1/16-12/16 } \\
\text { (Report Data } \\
\text { Period) }\end{array}$ \\
\hline Number of vehicles & 12 & 12 & 13 & 13 \\
\hline Period used for fuel and oil op analysis & $9 / 11-4 / 12$ & $5 / 12-2 / 13$ & $3 / 13-12 / 16$ & $1 / 16-12 / 16$ \\
\hline Total number of months in period & 8 & 10 & 46 & 12 \\
\hline Fuel and oil analysis base fleet mileage & 120,355 & 16,281 & $1,383,982$ & 416,662 \\
\hline Period used for maintenance op analysis & $9 / 11-4 / 12$ & $5 / 12-2 / 13$ & $3 / 13-12 / 16$ & $1 / 16-12 / 16$ \\
\hline Total number of months in period & 8 & 10 & 46 & 12 \\
\hline Maintenance analysis base fleet mileage & 147,129 & 19,296 & $1,490,809$ & 447,720 \\
\hline Average monthly mileage per vehicle & 1,598 & - & 2,629 & 2,870 \\
\hline Availability & $56 \%$ & - & $77 \%$ & $80 \%$ \\
\hline Fleet fuel usage $\left(\mathrm{H}_{2}\right.$ in $\mathrm{kg} /$ diesel in gallons $)$ & $18,016.0$ & $2,125.2$ & $236,786.7$ & $76,931.7$ \\
\hline Total roadcalls & 73 & - & 272 & 84 \\
\hline MBRC-all systems & 2,014 & - & 5,481 & 5,330 \\
\hline Propulsion roadcalls & 49 & - & 147 & 38 \\
\hline Propulsion MBRC & 3,000 & - & 10,142 & 11,782 \\
\hline Fleet miles $/ \mathrm{kg}$ hydrogen $\left(1.13 \mathrm{~kg} \mathrm{H}_{2}\right)$ & 6.68 & 7.66 & 5.84 & 5.42 \\
\hline Representative fleet MPG (energy equivalent) & 7.55 & 8.66 & 6.60 & 6.12 \\
\hline Hydrogen cost per kg & 9.34 & 8.47 & 8.32 & 7.03 \\
\hline Fuel cost per mile & 1.40 & 1.11 & 1.42 & 1.30 \\
\hline Total scheduled repair cost per mile & 0.26 & 0.08 & 0.20 & 0.26 \\
\hline Total unscheduled repair cost per mile & 1.05 & 3.11 & 0.67 & 0.85 \\
\hline Total maintenance cost per mile & 1.31 & 3.20 & 0.86 & 1.11 \\
\hline Total operating cost per mile & 2.71 & 4.30 & 2.29 & 2.41 \\
\hline Extended support cost (beginning in April 2014) & & & $\$ 1,125,101$ & $\$ 501,353$ \\
\hline Extra labor costs per mile (research, shuttling) & 0.27 & 7.07 & 0.06 & 0.05 \\
\hline $\begin{array}{l}\text { Total operating cost per mile (incl. extended } \\
\text { support and extra costs) }\end{array}$ & 2.98 & 11.38 & 3.10 & 3.57 \\
\hline
\end{tabular}

\section{Maintenance Costs}

\begin{tabular}{|l|r|r|r|r|}
\hline & \multicolumn{1}{|c|}{$\begin{array}{c}\text { ZEBA } \\
9 / 11-4 / 12 \\
\text { (Early } \\
\text { Service) }\end{array}$} & $\begin{array}{c}\text { ZEBA } \\
\text { 5/12-2/13 } \\
\text { (Station } \\
\text { Downtime } \\
\text { Period) }\end{array}$ & $\begin{array}{c}\text { ZEBA } \\
\text { 3/13-12/16 } \\
\text { (Data } \\
\text { Period) }\end{array}$ & $\begin{array}{c}\text { ZEBA } \\
\text { 1/16-12/16 } \\
\text { (Report Data } \\
\text { Period) }\end{array}$ \\
\hline Fleet mileage & 147,007 & 19,296 & $1,490,809$ & 447,720 \\
\hline Total parts cost & $31,727.9$ & $10,720.0$ & $449,978.0$ & $181,280.4$ \\
\hline Total labor hours & $3,219.70$ & $1,020.2$ & $16,787.5$ & $6,315.1$ \\
\hline Average labor cost $@ \$ 50.00$ per hour) & $160,985.00$ & $51,009.00$ & $839,374.00$ & $315,754.00$ \\
\hline Total maintenance cost & $192,712.88$ & $61,729.00$ & $1,289,351.95$ & $497,034.36$ \\
\hline Total maintenance cost per bus & $16,059.41$ & $5,144.08$ & $99,180.92$ & $38,233.41$ \\
\hline Total maintenance cost per mile & $\mathbf{1 . 3 1}$ & $\mathbf{3 . 2 0}$ & $\mathbf{0 . 8 6}$ & $\mathbf{1 . 1 1}$ \\
\hline
\end{tabular}


Breakdown of Maintenance Costs by Vehicle System

\begin{tabular}{|c|c|c|c|c|}
\hline & $\begin{array}{c}\text { ZEBA } \\
9 / 11-4 / 12 \\
\text { (Early } \\
\text { Service) }\end{array}$ & $\begin{array}{c}\text { ZEBA } \\
\text { 5/12-2/13 } \\
\text { (Station } \\
\text { Downtime } \\
\text { Period) }\end{array}$ & $\begin{array}{l}\text { ZEBA } \\
\text { 3/13-12/16 } \\
\text { (Data } \\
\text { Period) }\end{array}$ & $\begin{array}{c}\text { ZEBA } \\
\text { 1/16-12/16 } \\
\text { (Report Data } \\
\text { Period) }\end{array}$ \\
\hline Fleet mileage & 147,007 & 19,296 & $1,490,809$ & 447,720 \\
\hline \multicolumn{5}{|c|}{ Total Engine/Fuel-Related Systems (ATA VMRS $27,30,31,32,33,41,42,43,44,45,46,65$ ) } \\
\hline Parts cost & $5,957.71$ & $9,454.37$ & $254,594.67$ & $54,664.71$ \\
\hline Labor hours & $1,012.7$ & 672.0 & $6,739.4$ & $2,287.2$ \\
\hline Average labor cost & $50,633.50$ & $33,599.50$ & $336,972.00$ & $114,360.00$ \\
\hline Total cost (for system) & $56,591.21$ & $43,053.87$ & $591,566.67$ & $169,024.71$ \\
\hline Total cost (for system) per bus & $4,715.93$ & $3,587.82$ & $45,505.13$ & $13,001.90$ \\
\hline Total cost (for system) per mile & 0.38 & 2.23 & 0.40 & 0.38 \\
\hline \multicolumn{5}{|c|}{ Exhaust System Repairs (ATA VMRS 43) } \\
\hline Parts cost & 0.00 & 0.00 & 2479.67 & 122.47 \\
\hline Labor hours & 0.0 & 0.0 & 139.5 & 56.5 \\
\hline Average labor cost & 0.00 & 0.00 & $6,975.00$ & $2,825.00$ \\
\hline Total cost (for system) & 0.00 & 0.00 & $9,454.67$ & $2,947.47$ \\
\hline Total cost (for system) per bus & 0.00 & 0.00 & 727.28 & 226.73 \\
\hline Total cost (for system) per mile & 0.00 & 0.00 & 0.01 & 0.01 \\
\hline \multicolumn{5}{|c|}{ Fuel System Repairs (ATA VMRS 44) } \\
\hline Parts cost & 15.47 & 0.00 & $55,949.31$ & $3,093.62$ \\
\hline Labor hours & 166.7 & 30.4 & 664.9 & 156.5 \\
\hline Average labor cost & $8,335.00$ & $1,520.50$ & $33,246.00$ & $7,825.00$ \\
\hline Total cost (for system) & $8,350.47$ & $1,520.50$ & $89,195.31$ & $10,918.62$ \\
\hline Total cost (for system) per bus & 695.87 & 126.71 & $6,861.18$ & 839.89 \\
\hline Total cost (for system) per mile & 0.06 & 0.08 & 0.06 & 0.02 \\
\hline \multicolumn{5}{|c|}{ Power Plant (Engine) Repairs (ATA VMRS 45) } \\
\hline Parts cost & 260.89 & 165.98 & $3,076.38$ & $2,798.13$ \\
\hline Labor hours & 204.0 & 203.2 & $2,236.5$ & 910.0 \\
\hline Average labor cost & $10,200.50$ & $10,160.50$ & $111,826.00$ & $45,499.00$ \\
\hline Total cost (for system) & $10,461.39$ & $10,326.48$ & $114,902.38$ & $48,297.13$ \\
\hline Total cost (for system) per bus & 871.78 & 860.54 & $8,838.64$ & $3,715.16$ \\
\hline Total cost (for system) per mile & 0.07 & 0.54 & 0.08 & 0.11 \\
\hline \multicolumn{5}{|c|}{ Electric Propulsion Repairs (ATA VMRS 46) } \\
\hline Parts cost & $1,251.77$ & 0.00 & $66,669.60$ & $20,741.55$ \\
\hline Labor hours & 458.5 & 329.3 & $2,223.5$ & 709.6 \\
\hline Average labor cost & $22,924.00$ & $16,463.00$ & $111,173.50$ & $35,482.00$ \\
\hline Total cost (for system) & $24,175.77$ & $16,463.00$ & $177,843.10$ & $56,223.55$ \\
\hline Total cost (for system) per bus & $2,014.65$ & $1,371.92$ & $13,680.24$ & $4,324.89$ \\
\hline Total cost (for system) per mile & 0.16 & 0.85 & 0.12 & 0.13 \\
\hline
\end{tabular}


Breakdown of Maintenance Costs by Vehicle System (continued)

\begin{tabular}{|c|c|c|c|c|}
\hline & $\begin{array}{c}\text { ZEBA } \\
9 / 11-4 / 12 \\
\text { (Early } \\
\text { Service) }\end{array}$ & $\begin{array}{c}\text { ZEBA } \\
\text { 5/12-2/13 } \\
\text { (Station } \\
\text { Downtime } \\
\text { Period) }\end{array}$ & $\begin{array}{c}\text { ZEBA } \\
\text { 3/13-12/16 } \\
\text { (Data } \\
\text { Period) }\end{array}$ & $\begin{array}{c}\text { ZEBA } \\
\text { 1/16-12/16 } \\
\text { (Report Data } \\
\text { Period) }\end{array}$ \\
\hline \multicolumn{5}{|c|}{ Electrical System Repairs (ATA VMRS 30-Electrical General, 31-Charging, 32-Cranking, 33-Ignition) } \\
\hline Parts cost & $1,747.91$ & $2,823.98$ & $9,553.30$ & $3,731.66$ \\
\hline Labor hours & 81.3 & 46.7 & 447.4 & 201.3 \\
\hline Average labor cost & $4,064.50$ & $2,337.00$ & $22,372.00$ & $10,062.50$ \\
\hline Total cost (for system) & $5,812.41$ & $5,160.98$ & $31,925.30$ & $13,794.16$ \\
\hline Total cost (for system) per bus & 484.37 & 430.08 & $2,455.79$ & $1,061.09$ \\
\hline Total cost (for system) per mile & 0.04 & 0.27 & 0.02 & 0.03 \\
\hline \multicolumn{5}{|c|}{ Air Intake System Repairs (ATA VMRS 41) } \\
\hline Parts cost & $2,152.28$ & $6,096.88$ & $59,473.08$ & $7,138.60$ \\
\hline Labor hours & 8.7 & 13.6 & 312.2 & 4.0 \\
\hline Average labor cost & 435.50 & 678.00 & $15,611.00$ & 200.00 \\
\hline Total cost (for system) & $2,587.78$ & $6,774.88$ & $75,084.08$ & $7,338.60$ \\
\hline Total cost (for system) per bus & 215.65 & 564.57 & $5,775.70$ & 564.51 \\
\hline Total cost (for system) per mile & 0.02 & 0.35 & 0.05 & 0.02 \\
\hline \multicolumn{5}{|c|}{ Cooling System Repairs (ATA VMRS 42) } \\
\hline Parts cost & 529.39 & 367.53 & $57,393.33$ & $17,038.68$ \\
\hline Labor hours & 93.5 & 48.8 & 715.4 & 249.3 \\
\hline Average labor cost & $4,674.00$ & $2,440.50$ & $35,768.50$ & $12,466.50$ \\
\hline Total cost (for system) & $5,203.39$ & $2,808.03$ & $93,161.83$ & $29,505.18$ \\
\hline Total cost (for system) per bus & 433.62 & 234.00 & $7,166.29$ & $2,269.63$ \\
\hline Total cost (for system) per mile & 0.04 & 0.15 & 0.06 & 0.07 \\
\hline \multicolumn{5}{|c|}{ Hydraulic System Repairs (ATA VMRS 65) } \\
\hline Parts cost & 0.00 & 0.00 & 0.00 & 0.00 \\
\hline Labor hours & 0.0 & 0.0 & 0.0 & 0.0 \\
\hline Average labor cost & 0.00 & 0.00 & 0.00 & 0.00 \\
\hline Total cost (for system) & 0.00 & 0.00 & 0.00 & 0.00 \\
\hline Total cost (for system) per bus & 0.00 & 0.00 & 0.00 & 0.00 \\
\hline Total cost (for system) per mile & 0.00 & 0.00 & 0.00 & 0.00 \\
\hline \multicolumn{5}{|c|}{ General Air System Repairs (ATA VMRS 10) } \\
\hline Parts cost & $3,875.75$ & 0.00 & $95,045.40$ & $85,140.99$ \\
\hline Labor hours & 66.4 & 10.3 & 475.5 & 256.8 \\
\hline Average labor cost & $3,321.50$ & 516.00 & $23,773.50$ & $12,841.50$ \\
\hline Total cost (for system) & $7,197.25$ & 516.00 & $118,818.90$ & $97,982.49$ \\
\hline Total cost (for system) per bus & 599.77 & 43.00 & $9,139.92$ & $7,537.11$ \\
\hline Total cost (for system) per mile & 0.05 & 0.03 & 0.08 & 0.22 \\
\hline
\end{tabular}


Breakdown of Maintenance Costs by Vehicle System (continued)

\begin{tabular}{|c|c|c|c|c|}
\hline & $\begin{array}{c}\text { ZEBA } \\
9 / 11-4 / 12 \\
\text { (Early } \\
\text { Service) }\end{array}$ & $\begin{array}{c}\text { ZEBA } \\
\text { 5/12-2/13 } \\
\text { (Station } \\
\text { Downtime } \\
\text { Period) }\end{array}$ & $\begin{array}{c}\text { ZEBA } \\
\text { 3/13-12/16 } \\
\text { (Data } \\
\text { Period) }\end{array}$ & $\begin{array}{c}\text { ZEBA } \\
\text { 1/16-12/16 } \\
\text { (Report Data } \\
\text { Period) }\end{array}$ \\
\hline \multicolumn{5}{|c|}{ Brake System Repairs (ATA VMRS 13) } \\
\hline Parts cost & 321.45 & 0.00 & $15,177.71$ & $3,079.45$ \\
\hline Labor hours & 24.0 & 0.0 & 335.9 & 128.5 \\
\hline Average labor cost & $1,200.00$ & 0.00 & $16,797.00$ & $6,425.00$ \\
\hline Total cost (for system) & $1,521.45$ & 0.00 & $31,974.71$ & $9,504.45$ \\
\hline Total cost (for system) per bus & 126.79 & 0.00 & $2,459.59$ & 731.11 \\
\hline Total cost (for system) per mile & 0.01 & 0.00 & 0.02 & 0.02 \\
\hline \multicolumn{5}{|c|}{ Transmission Repairs (ATA VMRS 27) } \\
\hline Parts cost & 0.00 & 0.00 & 0.00 & 0.00 \\
\hline Labor hours & 0.0 & 0.0 & 0.0 & 0.0 \\
\hline Average labor cost & 0.00 & 0.00 & 0.00 & 0.00 \\
\hline Total cost (for system) & 0.00 & 0.00 & 0.00 & 0.00 \\
\hline Total cost (for system) per bus & 0.00 & 0.00 & 0.00 & 0.00 \\
\hline Total cost (for system) per mile & 0.00 & 0.00 & 0.00 & 0.00 \\
\hline \multicolumn{5}{|c|}{ Inspections Only - no parts replacements (101) } \\
\hline Parts cost & 0.00 & 0.00 & 0.00 & 0.00 \\
\hline Labor hours & 669.0 & 19.5 & $3,914.0$ & $1,692.6$ \\
\hline Average labor cost & $33,449.50$ & 975.00 & $195,702.00$ & $84,632.00$ \\
\hline Total cost (for system) & $33,449.50$ & 975.00 & $195,702.00$ & $84,632.00$ \\
\hline Total cost (for system) per bus & $2,787.46$ & 81.25 & $15,054.00$ & $6,510.15$ \\
\hline Total cost (for system) per mile & 0.23 & 0.05 & 0.13 & 0.19 \\
\hline \multicolumn{5}{|c|}{$\begin{array}{l}\text { Cab, Body, and Accessories Systems Repairs (ATA VMRS 02-Cab and Sheet Metal, 50-Accessories, } \\
\text { 71-Body) }\end{array}$} \\
\hline Parts cost & $18,550.84$ & $1,120.55$ & $37,091.23$ & $22,975.28$ \\
\hline Labor hours & $1,281.2$ & 257.9 & $4,109.2$ & $1,404.6$ \\
\hline Average labor cost & $64,059.00$ & $12,896.50$ & $205,462.00$ & $70,230.50$ \\
\hline Total cost (for system) & $82,609.84$ & $14,017.05$ & $242,553.23$ & $93,205.78$ \\
\hline Total cost (for system) per bus & $6,884.15$ & $1,168.09$ & $18,657.94$ & $7,169.68$ \\
\hline Total cost (for system) per mile & 0.56 & 0.73 & 0.16 & 0.21 \\
\hline \multicolumn{5}{|c|}{ HVAC System Repairs (ATA VMRS 01) } \\
\hline Parts cost & 897.40 & 0.00 & $27,902.66$ & $10,249.58$ \\
\hline Labor hours & 14.7 & 5.0 & 374.3 & 162.0 \\
\hline Average labor cost & 735.00 & 249.00 & $18,717.00$ & $8,099.50$ \\
\hline Total cost (for system) & $1,632.40$ & 249.00 & $46,619.66$ & $18,349.08$ \\
\hline Total cost (for system) per bus & 136.03 & 20.75 & $3,586.13$ & $1,411.47$ \\
\hline Total cost (for system) per mile & 0.01 & 0.01 & 0.03 & 0.04 \\
\hline
\end{tabular}


Breakdown of Maintenance Costs by Vehicle System (continued)

\begin{tabular}{|c|c|c|c|c|}
\hline & $\begin{array}{c}\text { ZEBA } \\
9 / 11-4 / 12 \\
\text { (Early } \\
\text { Service) }\end{array}$ & $\begin{array}{l}\text { ZEBA } \\
5 / 12-2 / 13 \\
\text { (Station } \\
\text { Downtime } \\
\text { Period) }\end{array}$ & $\begin{array}{c}\text { ZEBA } \\
\text { 3/13-12/16 } \\
\text { (Data } \\
\text { Period) }\end{array}$ & $\begin{array}{c}\text { ZEBA } \\
\text { 1/16-12/16 } \\
\text { (Report Data } \\
\text { Period) }\end{array}$ \\
\hline \multicolumn{5}{|c|}{ Lighting System Repairs (ATA VMRS 34) } \\
\hline Parts cost & 290.00 & 27.62 & $2,613.73$ & 942.34 \\
\hline Labor hours & 24.4 & 3.3 & 211.4 & 70.0 \\
\hline Average labor cost & $1,220.50$ & 165.50 & $10,569.00$ & $3,499.50$ \\
\hline Total cost (for system) & $1,510.50$ & 193.12 & $13,182.73$ & $4,441.84$ \\
\hline Total cost (for system) per bus & 125.88 & 16.09 & $1,014.06$ & 341.68 \\
\hline Total cost (for system) per mile & 0.01 & 0.01 & 0.01 & 0.01 \\
\hline \multicolumn{5}{|c|}{ Frame, Steering, and Suspension Repairs (ATA VMRS 14-Frame, 15-Steering, 16-Suspension) } \\
\hline Parts cost & $1,751.91$ & 108.48 & $10,180.44$ & $2,093.13$ \\
\hline Labor hours & 103.2 & 52.2 & 475.8 & 207.0 \\
\hline Average labor cost & $5,161.00$ & $2,607.50$ & $23,790.00$ & $10,349.50$ \\
\hline Total cost (for system) & $6,912.91$ & $2,715.98$ & $33,970.44$ & $12,442.63$ \\
\hline Total cost (for system) per bus & 576.08 & 226.33 & $2,613.11$ & 957.13 \\
\hline Total cost (for system) per mile & 0.05 & 0.14 & 0.02 & 0.03 \\
\hline \multicolumn{5}{|c|}{$\begin{array}{l}\text { Axle, Wheel, and Drive Shaft Repairs (ATA VMRS 11-Front Axle, 18-Wheels, 22-Rear Axle, 24-Drive } \\
\text { Shaft) }\end{array}$} \\
\hline Parts cost & 5.48 & 0.00 & $7,372.11$ & $2,134.88$ \\
\hline Labor hours & 22.6 & 0.0 & 146.8 & 104.3 \\
\hline Average labor cost & $1,131.50$ & 0.00 & $7,341.50$ & $5,216.50$ \\
\hline Total cost (for system) & $1,136.98$ & 0.00 & $14,713.61$ & $7,351.38$ \\
\hline Total cost (for system) per bus & 94.75 & 0.00 & $1,131.82$ & 565.49 \\
\hline Total cost (for system) per mile & 0.01 & 0.00 & 0.01 & 0.02 \\
\hline \multicolumn{5}{|l|}{ Tire Repairs (ATA VMRS 17) } \\
\hline Parts cost & 0.00 & 0.00 & 0.00 & 0.00 \\
\hline Labor hours & 0.0 & 0.0 & 5.0 & 2.0 \\
\hline Average labor cost & 0.00 & 0.00 & 250.00 & 100.00 \\
\hline Total cost (for system) & 0.00 & 0.00 & 250.00 & 100.00 \\
\hline Total cost (for system) per bus & 0.00 & 0.00 & 19.23 & 7.69 \\
\hline Total cost (for system) per mile & 0.00 & 0.00 & 0.00 & 0.00 \\
\hline
\end{tabular}




\section{Notes}

1. To compare the hydrogen fuel dispensed and fuel economy to diesel, the hydrogen dispensed was also converted into diesel energy equivalent gallons. Actual energy content will vary by locations, but the general energy conversions are as follows:

Lower heating value $(\mathrm{LHV})$ for hydrogen $=51,532 \mathrm{Btu} / \mathrm{lb}$

LHV for diesel $=128,400 \mathrm{Btu} / \mathrm{lb}$

$1 \mathrm{~kg}=2.205 \mathrm{lb}$

$51,532 \mathrm{Btu} / \mathrm{lb}$ * $2.205 \mathrm{lb} / \mathrm{kg}=113,628 \mathrm{Btu} / \mathrm{kg}$

Diesel $/$ hydrogen $=128,400 \mathrm{Btu} / \mathrm{gal} / 113,628 \mathrm{Btu} / \mathrm{kg}=1.13 \mathrm{~kg} / \mathrm{diesel}$ gal

2. The propulsion-related systems were chosen to include only those systems of the vehicles that could be affected directly by the selection of a fuel/advanced technology.

3. ATA VMRS coding is based on parts that were replaced. If there was no part replaced in a given repair, then the code was chosen by the system being worked on.

4. In general, inspections (with no part replacements) were included only in the overall totals (not by system). Category 101 was created to track labor costs for PM inspections.

5. ATA VMRS 02-Cab and Sheet Metal represents seats, doors, etc.; ATA VMRS 50-Accessories represents things like fire extinguishers, test kits, etc.; ATA VMRS 71-Body represents mostly windows and windshields.

6. Average labor cost is assumed to be $\$ 50$ per hour.

7. Warranty costs are not included. 


\section{Appendix C: ZEBA FCEB Fleet Summary Statistics-SI Units}

\begin{tabular}{|c|c|c|c|c|}
\hline & $\begin{array}{c}\text { ZEBA } \\
9 / 11-4 / 12 \\
\text { (Early } \\
\text { Service) }\end{array}$ & $\begin{array}{c}\text { ZEBA } \\
5 / 12-2 / 13 \\
\text { (Station } \\
\text { Downtime } \\
\text { Period) }\end{array}$ & $\begin{array}{c}\text { ZEBA } \\
\text { 3/13-12/16 } \\
\text { (Data } \\
\text { Period) }\end{array}$ & $\begin{array}{c}\text { ZEBA } \\
\text { 1/16-12/16 } \\
\text { (Report } \\
\text { Data } \\
\text { Period) }\end{array}$ \\
\hline Number of vehicles & 12 & 12 & 13 & 13 \\
\hline Period used for fuel and oil op analysis & $9 / 11-4 / 12$ & $5 / 12-2 / 13$ & $3 / 13-12 / 16$ & $1 / 16-12 / 16$ \\
\hline Total number of months in period & 8 & 10 & 46 & 12 \\
\hline Fuel and oil analysis base fleet kilometers & 193,687 & 26,201 & $2,227,242$ & 670,534 \\
\hline Period used for maintenance op analysis & $9 / 11-4 / 12$ & $5 / 12-2 / 13$ & $3 / 13-12 / 16$ & $1 / 16-12 / 16$ \\
\hline Total number of months in period & 8 & 10 & 46 & 12 \\
\hline Maintenance analysis base fleet kilometers & 236,775 & 31,053 & $2,399,159$ & 720,516 \\
\hline Average monthly kilometers per vehicle & 2,572 & - & 4,231 & 4,619 \\
\hline Availability & 1 & - & $77 \%$ & $80 \%$ \\
\hline Fleet fuel usage ( $\mathrm{H}_{2}$ in $\mathrm{kg} /$ diesel in liters) & 18,016 & 2,125 & 236,787 & 76,932 \\
\hline Total roadcalls & 73 & - & 272 & 84 \\
\hline KMBRC-all systems & 3,243 & - & 8,820 & 8,578 \\
\hline Propulsion roadcalls & 49 & - & 147 & 38 \\
\hline Propulsion KMBRC & 4,832 & - & 16,321 & 18,961 \\
\hline Fleet $\mathrm{kg}$ hydrogen/100 km (1.13 $\left.\mathrm{kg} \mathrm{H}_{2}\right)$ & 9.30 & 8.11 & 10.63 & 11.47 \\
\hline Representative fleet fuel consumption (L/100 km) & 31.16 & 27.17 & 35.61 & 38.43 \\
\hline Hydrogen cost per kg & 9.34 & 8.47 & 8.32 & 7.03 \\
\hline Fuel cost per kilometer & 0.87 & 0.69 & 0.88 & 0.81 \\
\hline Total scheduled repair cost per kilometer & 0.01 & 0.05 & 0.12 & 0.16 \\
\hline Total unscheduled repair cost per kilometer & 0.25 & 1.94 & 0.41 & 0.53 \\
\hline Total maintenance cost per kilometer & 0.26 & 1.99 & 0.54 & 0.69 \\
\hline Total operating cost per kilometer & 1.13 & 2.67 & 1.42 & 1.50 \\
\hline Extended warranty cost (beginning in April 2014) & & & $\$ 1,125,101$ & $\$ 501,353$ \\
\hline Extra labor costs per kilometer (research, shuttling) & 0.17 & 4.40 & 0.04 & 0.03 \\
\hline $\begin{array}{l}\text { Total operating cost per kilometer (incl. warranty } \\
\text { and extra costs) }\end{array}$ & 1.30 & 7.07 & 1.93 & 2.22 \\
\hline
\end{tabular}

\section{Maintenance Costs}

\begin{tabular}{|l|r|r|r|r|}
\hline & \multicolumn{1}{|c|}{$\begin{array}{c}\text { ZEBA } \\
9 / 11-4 / 12 \\
\text { (Early } \\
\text { Service) }\end{array}$} & $\begin{array}{r}\text { ZEBA } \\
\text { 5/12-2/13 } \\
\text { (Station } \\
\text { Downtime } \\
\text { Period) }\end{array}$ & $\begin{array}{r}\text { ZEBA } \\
3 / 13-12 / 16 \\
\text { (Data } \\
\text { Period) }\end{array}$ & $\begin{array}{c}\text { ZEBA } \\
1 / 16-12 / 16 \\
\text { (Report Data } \\
\text { Period) }\end{array}$ \\
\hline Fleet mileage & 236,775 & 31,053 & $2,399,159$ & 720,516 \\
\hline Total parts cost & $31,727.9$ & $10,720.0$ & $449,978.0$ & $181,280.4$ \\
\hline Total labor hours & $3,219.70$ & $1,020.18$ & $16,787.48$ & $6,315.08$ \\
\hline Average labor cost (@ \$50.00 per hour) & $160,985.00$ & $51,009.00$ & $839,374.00$ & $315,754.00$ \\
\hline Total maintenance cost & $192,712.88$ & $61,729.00$ & $1,289,351.95$ & $497,034.36$ \\
\hline Total maintenance cost per bus & $16,059.41$ & $5,144.08$ & $99,180.92$ & $38,233.41$ \\
\hline Total maintenance cost per kilometer & $\mathbf{0 . 8 1}$ & $\mathbf{1 . 9 9}$ & $\mathbf{0 . 5 4}$ & $\mathbf{0 . 6 9}$ \\
\hline
\end{tabular}




\section{Appendix D: ZEBA FCEB Monthly Maintenance Analysis Graphs}

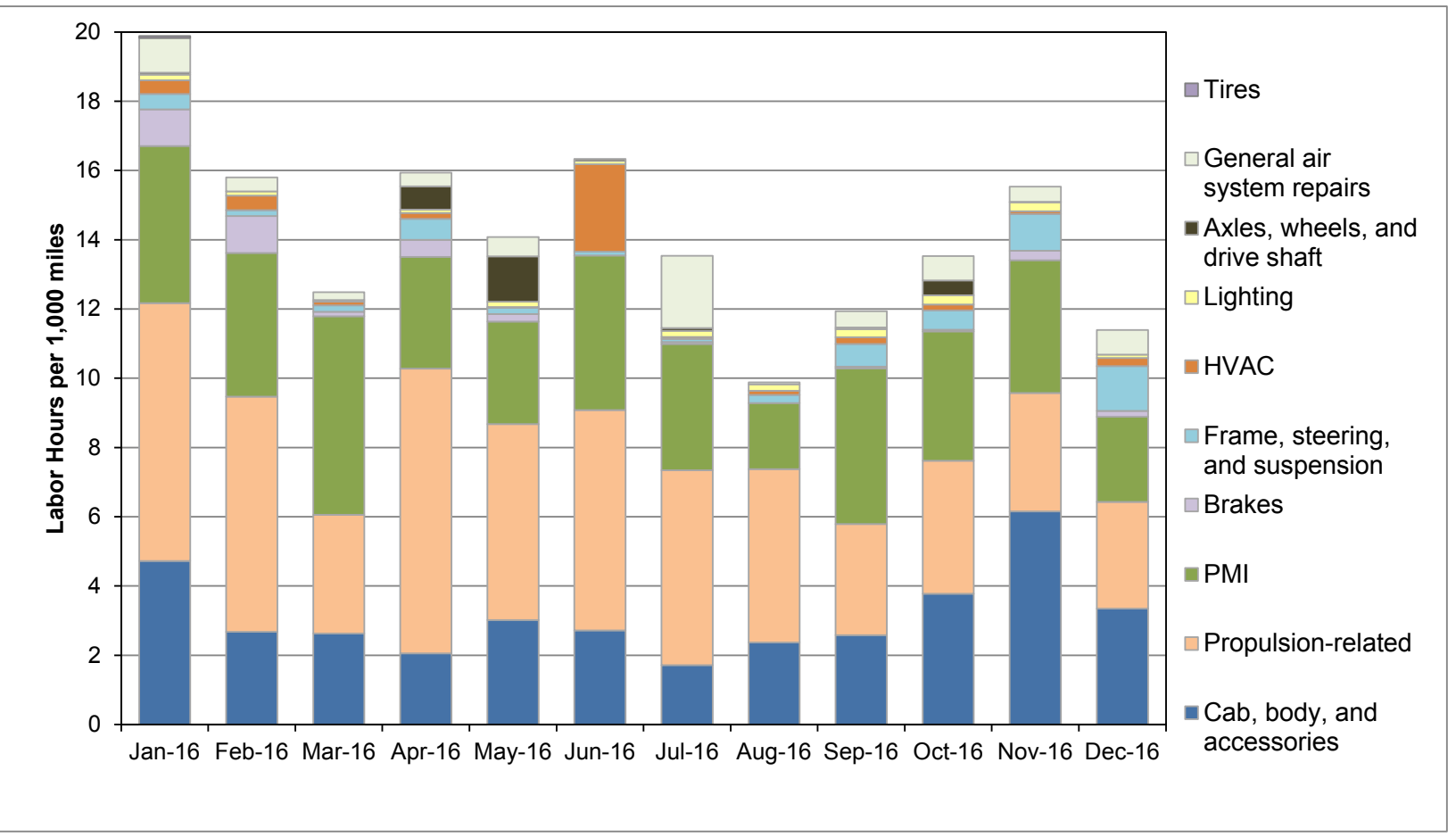

Figure D-1. Monthly labor hours by category for the ZEBA FCEBs

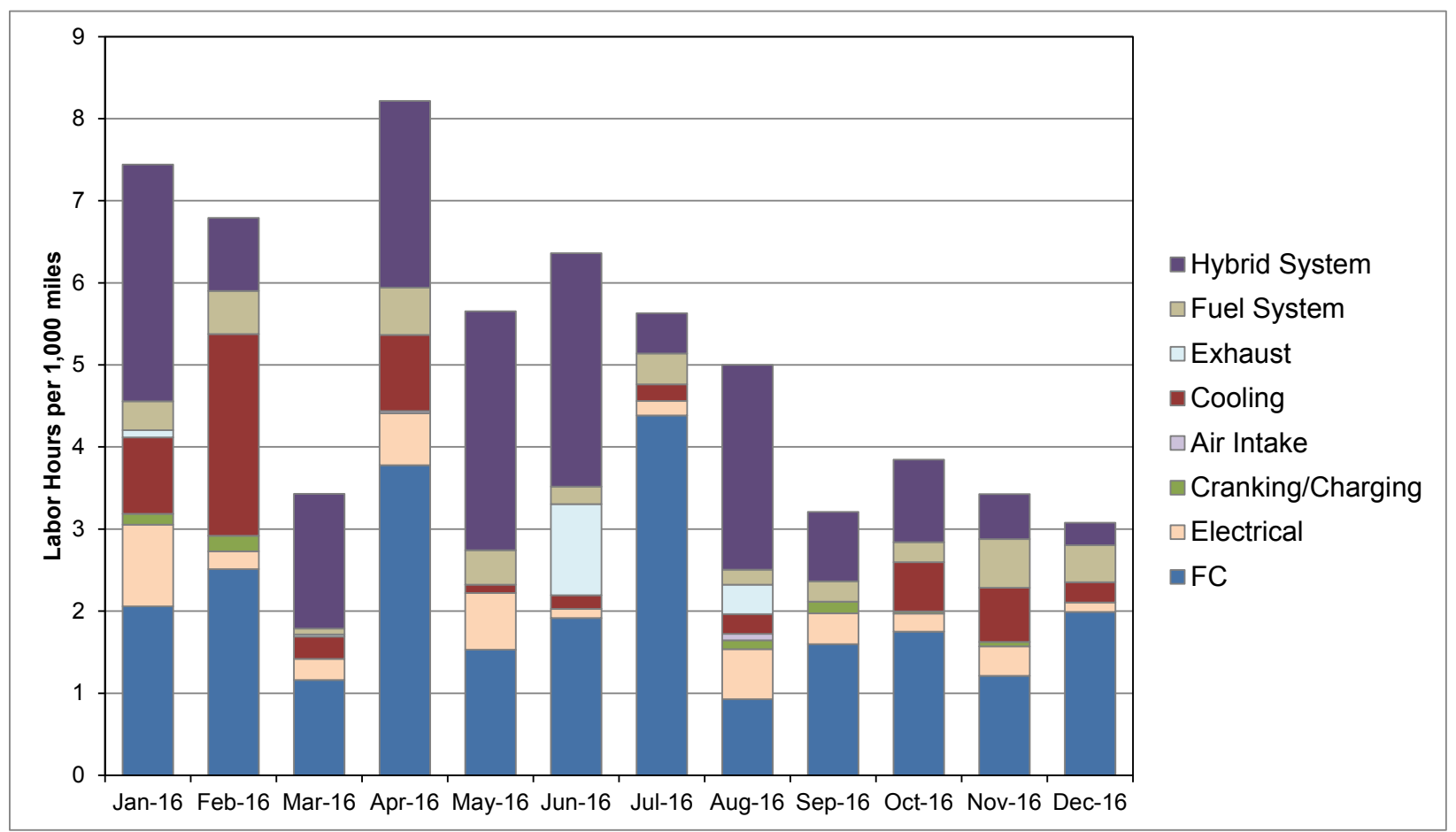

Figure D-2. Monthly propulsion system labor hours by subcategory for the ZEBA FCEBs 


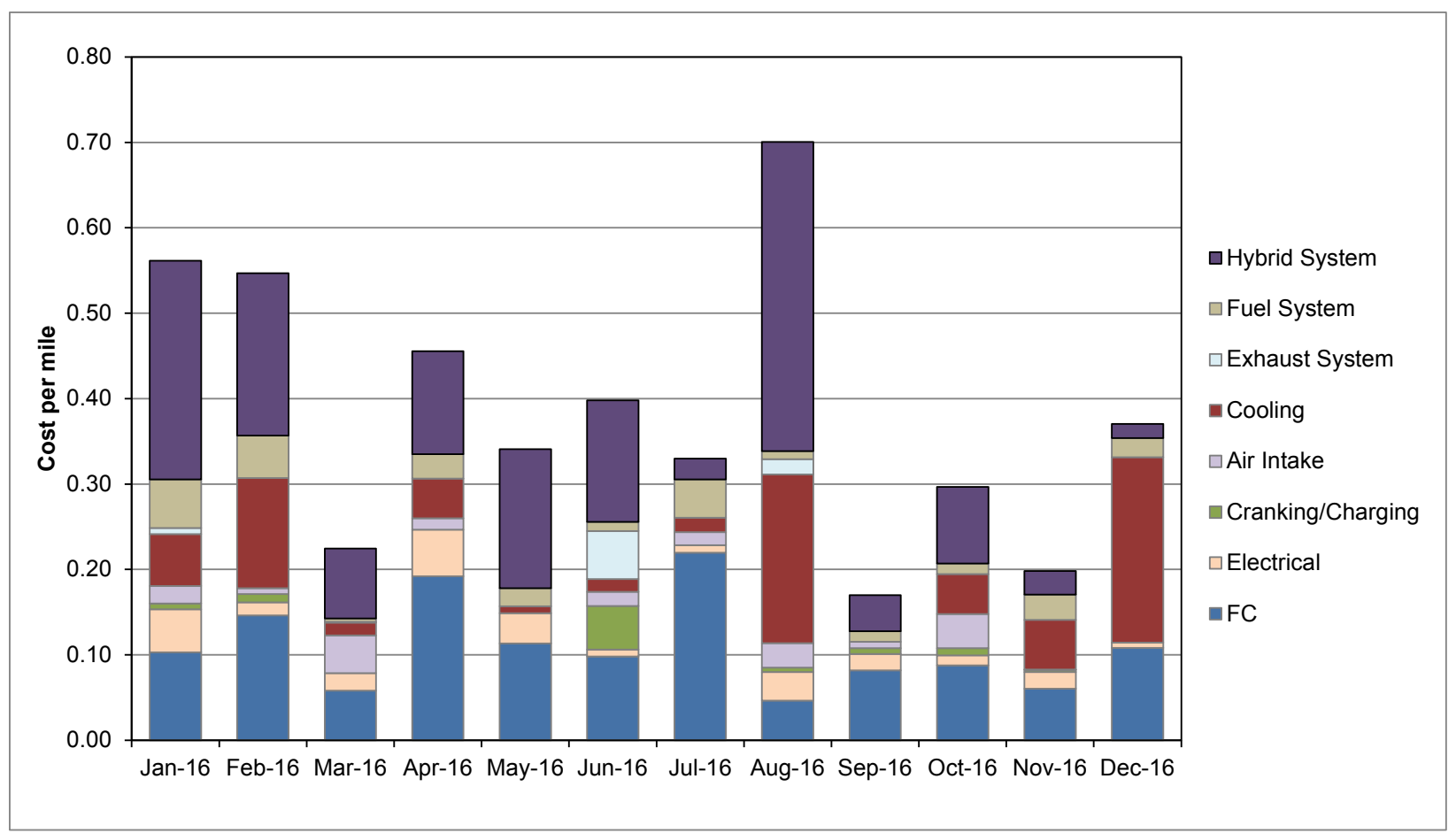

Figure D-3. Monthly propulsion system cost per mile by subcategory for the ZEBA FCEBs 


\section{Appendix E: Diesel Fleet Summary Statistics}

\section{Gillig Diesel Fleet Operations and Economics}

\begin{tabular}{|l|r|r|}
\hline & \multicolumn{1}{|c|}{$\begin{array}{c}\text { Gillig Diesel } \\
7 / 13-12 / 16 \\
\text { (Data Period) }\end{array}$} & $\begin{array}{c}\text { Gillig Diesel } \\
1 / 16-12 / 16 \\
\text { (Report Data } \\
\text { Period) }\end{array}$ \\
\hline Number of vehicles & 10 & 10 \\
\hline Period used for fuel and oil op analysis & $7 / 13-12 / 16$ & $1 / 16-12 / 16$ \\
\hline Total number of months in period & 42 & 12 \\
\hline Fuel and oil analysis base fleet mileage & $1,778,280$ & 512,268 \\
\hline Period used for maintenance op analysis & $7 / 13-12 / 16$ & $1 / 16-12 / 16$ \\
\hline Total number of months in period & 42 & 12 \\
\hline Maintenance analysis base fleet mileage & $1,913,952$ & 523,220 \\
\hline Average monthly mileage per vehicle & 4,557 & 4,360 \\
\hline Availability & $89 \%$ & $90 \%$ \\
\hline Fleet fuel usage (gallons) & $417,611.0$ & $121,568.0$ \\
\hline Roadcalls & 287 & 87 \\
\hline MBRC-all systems & 6,669 & 6,014 \\
\hline Propulsion roadcalls & 142 & 52 \\
\hline Propulsion MBRC & 13,479 & 10,062 \\
\hline Representative fleet mpg (energy equivalent) & 4.26 & 4.21 \\
\hline Diesel cost per gallon & 2.29 & 1.55 \\
\hline Fuel cost per mile & $\mathbf{0 . 5 4}$ & $\mathbf{0 . 3 7}$ \\
\hline Total scheduled repair cost per mile & 0.13 & 0.15 \\
\hline Total unscheduled repair cost per mile & 0.25 & 0.41 \\
\hline Total maintenance cost per mile & $\mathbf{0 . 3 9}$ & $\mathbf{0 . 5 6}$ \\
\hline Total operating cost per mile & $\mathbf{0 . 9 2}$ & $\mathbf{0 . 9 2}$ \\
\hline
\end{tabular}

\section{Maintenance Costs}

\begin{tabular}{|l|r|r|}
\hline & \multicolumn{1}{|c|}{$\begin{array}{r}\text { Gillig Diesel } \\
7 / 13-12 / 16 \\
\text { (Data Period) }\end{array}$} & $\begin{array}{r}\text { Gillig Diesel } \\
1 / 16-12 / 16 \\
\text { (Report Data } \\
\text { Period) }\end{array}$ \\
\hline Fleet mileage & $1,913,952$ & 523,220 \\
\hline Total parts cost & $228,712.5$ & $106,128.7$ \\
\hline Total labor hours & 10229.7 & 3697.7 \\
\hline Average labor cost $@ \$ 50.00$ per hour) & $511,482.50$ & $184,885.00$ \\
\hline Total maintenance cost & $740,195.03$ & $291,013.73$ \\
\hline Total maintenance cost per bus & $74,019.50$ & $29,101.37$ \\
\hline Total maintenance cost per mile & $\mathbf{0 . 3 9}$ & $\mathbf{0 . 5 6}$ \\
\hline
\end{tabular}




\section{Breakdown of Maintenance Costs by Vehicle System}

\begin{tabular}{|c|c|c|}
\hline & $\begin{array}{c}\text { Gillig Diesel } \\
7 / 13-12 / 16 \\
\text { (Data Period) }\end{array}$ & $\begin{array}{c}\text { Gillig Diesel } \\
\text { 1/16-12/16 } \\
\text { (Report Data } \\
\text { Period) }\end{array}$ \\
\hline Fleet mileage & $1,913,952$ & 523,220 \\
\hline \multicolumn{3}{|c|}{$\begin{array}{l}\text { Total Engine/Fuel-Related Systems (ATA VMRS 27, 30, 31, 32, 33, 41, 42, 43, 44, 45, } \\
46,65 \text { ) }\end{array}$} \\
\hline Parts cost & $92,414.86$ & $35,293.83$ \\
\hline Labor hours & $2,278.6$ & 936.5 \\
\hline Average labor cost & $113,929.00$ & $46,824.50$ \\
\hline Total cost (for system) & $206,343.86$ & $82,118.33$ \\
\hline Total cost (for system) per bus & $20,634.39$ & $8,211.83$ \\
\hline Total cost (for system) per mile & 0.11 & 0.16 \\
\hline \multicolumn{3}{|c|}{ Exhaust System Repairs (ATA VMRS 43) } \\
\hline Parts cost & $25,007.80$ & $17,027.53$ \\
\hline Labor hours & 482.9 & 269.6 \\
\hline Average labor cost & $24,145.00$ & $13,481.00$ \\
\hline Total cost (for system) & $49,152.80$ & $30,508.53$ \\
\hline Total cost (for system) per bus & $4,915.28$ & $3,050.85$ \\
\hline Total cost (for system) per mile & 0.03 & 0.06 \\
\hline \multicolumn{3}{|c|}{ Fuel System Repairs (ATA VMRS 44) } \\
\hline Parts cost & $9,623.42$ & $3,002.96$ \\
\hline Labor hours & 124.9 & 47.0 \\
\hline Average labor cost & $6,243.00$ & $2,350.00$ \\
\hline Total cost (for system) & $15,866.42$ & $5,352.96$ \\
\hline Total cost (for system) per bus & $1,586.64$ & 535.30 \\
\hline Total cost (for system) per mile & 0.01 & 0.01 \\
\hline \multicolumn{3}{|c|}{ Power Plant (Engine) Repairs (ATA VMRS 45) } \\
\hline Parts cost & $13,090.88$ & $3,265.31$ \\
\hline Labor hours & 551.6 & 231.4 \\
\hline Average labor cost & $27,577.50$ & $11,568.50$ \\
\hline Total cost (for system) & $40,668.38$ & $14,833.81$ \\
\hline Total cost (for system) per bus & $4,066.84$ & $1,483.38$ \\
\hline Total cost (for system) per mile & 0.02 & 0.03 \\
\hline \multicolumn{3}{|c|}{ Electric Propulsion Repairs (ATA VMRS 46) } \\
\hline Parts cost & 0.00 & 0.00 \\
\hline Labor hours & 0.0 & 0.0 \\
\hline Average labor cost & 0.00 & 0.00 \\
\hline Total cost (for system) & 0.00 & 0.00 \\
\hline Total cost (for system) per bus & 0.00 & 0.00 \\
\hline Total cost (for system) per mile & 0.00 & 0.00 \\
\hline
\end{tabular}


Breakdown of Maintenance Costs by Vehicle System (continued)

\begin{tabular}{|c|c|c|}
\hline & $\begin{array}{c}\text { Gillig Diesel } \\
7 / 13-12 / 16 \\
\text { (Data Period) }\end{array}$ & $\begin{array}{c}\text { Gillig Diesel } \\
\text { 1/16-12/16 } \\
\text { (Report Data } \\
\text { Period) }\end{array}$ \\
\hline \multicolumn{3}{|c|}{$\begin{array}{l}\text { Electrical System Repairs (ATA VMRS 30-Electrical General, 31-Charging, 32- } \\
\text { Cranking, 33-Ignition) }\end{array}$} \\
\hline Parts cost & $17,333.63$ & $4,013.26$ \\
\hline Labor hours & 415.5 & 135.9 \\
\hline Average labor cost & $20,775.50$ & $6,795.50$ \\
\hline Total cost (for system) & $38,109.13$ & $10,808.76$ \\
\hline Total cost (for system) per bus & $3,810.91$ & $1,080.88$ \\
\hline Total cost (for system) per mile & 0.02 & 0.02 \\
\hline \multicolumn{3}{|c|}{ Air Intake System Repairs (ATA VMRS 41) } \\
\hline Parts cost & $13,892.59$ & $4,007.26$ \\
\hline Labor hours & 163.0 & 38.4 \\
\hline Average labor cost & $8,151.50$ & $1,919.00$ \\
\hline Total cost (for system) & $22,044.09$ & $5,926.26$ \\
\hline Total cost (for system) per bus & $2,204.41$ & 592.63 \\
\hline Total cost (for system) per mile & 0.01 & 0.01 \\
\hline \multicolumn{3}{|c|}{ Cooling System Repairs (ATA VMRS 42) } \\
\hline Parts cost & $9,583.75$ & $2,775.39$ \\
\hline Labor hours & 308.8 & 155.8 \\
\hline Average labor cost & $15,437.50$ & $7,789.50$ \\
\hline Total cost (for system) & $25,021.25$ & $10,564.89$ \\
\hline Total cost (for system) per bus & $2,502.13$ & $1,056.49$ \\
\hline Total cost (for system) per mile & 0.01 & 0.02 \\
\hline \multicolumn{3}{|c|}{ Hydraulic System Repairs (ATA VMRS 65) } \\
\hline Parts cost & $2,099.19$ & 679.01 \\
\hline Labor hours & 16.1 & 4.0 \\
\hline Average labor cost & 804.00 & 200.00 \\
\hline Total cost (for system) & $2,903.19$ & 879.01 \\
\hline Total cost (for system) per bus & 290.32 & 87.90 \\
\hline Total cost (for system) per mile & 0.00 & 0.00 \\
\hline \multicolumn{3}{|c|}{ General Air System Repairs (ATA VMRS 10) } \\
\hline Parts cost & $32,556.71$ & $26,166.47$ \\
\hline Labor hours & 262.0 & 140.8 \\
\hline Average labor cost & $13,102.00$ & $7,041.50$ \\
\hline Total cost (for system) & $45,658.71$ & $33,207.97$ \\
\hline Total cost (for system) per bus & $4,565.87$ & $3,320.80$ \\
\hline Total cost (for system) per mile & 0.02 & 0.06 \\
\hline
\end{tabular}


Breakdown of Maintenance Costs by Vehicle System (continued)

\begin{tabular}{|c|c|c|}
\hline & $\begin{array}{c}\text { Gillig Diesel } \\
7 / 13-12 / 16 \\
\text { (Data Period) }\end{array}$ & $\begin{array}{c}\text { Gillig Diesel } \\
\text { 1/16-12/16 } \\
\text { (Report Data } \\
\text { Period) }\end{array}$ \\
\hline \multicolumn{3}{|c|}{ Brake System Repairs (ATA VMRS 13) } \\
\hline Parts cost & $39,354.38$ & $19,545.08$ \\
\hline Labor hours & 755.4 & 298.6 \\
\hline Average labor cost & $37,767.50$ & $14,929.00$ \\
\hline Total cost (for system) & $77,121.88$ & $34,474.08$ \\
\hline Total cost (for system) per bus & $7,712.19$ & $3,447.41$ \\
\hline Total cost (for system) per mile & 0.04 & 0.07 \\
\hline \multicolumn{3}{|c|}{ Transmission Repairs (ATA VMRS 27) } \\
\hline Parts cost & $1,783.59$ & 523.10 \\
\hline Labor hours & 215.9 & 54.4 \\
\hline Average labor cost & $10,795.00$ & $2,721.00$ \\
\hline Total cost (for system) & $12,578.59$ & $3,244.10$ \\
\hline Total cost (for system) per bus & $1,257.86$ & 324.41 \\
\hline Total cost (for system) per mile & 0.01 & 0.01 \\
\hline \multicolumn{3}{|c|}{$\begin{array}{l}\text { Inspections Only - no parts replacements } \\
\text { (101) }\end{array}$} \\
\hline Parts cost & 0.00 & 0.00 \\
\hline Labor hours & $2,643.1$ & 832.6 \\
\hline Average labor cost & $132,154.50$ & $41,630.00$ \\
\hline Total cost (for system) & $132,154.50$ & $41,630.00$ \\
\hline Total cost (for system) per bus & $13,215.45$ & $4,163.00$ \\
\hline Total cost (for system) per mile & 0.07 & 0.08 \\
\hline \multicolumn{3}{|c|}{$\begin{array}{l}\text { Cab, Body, and Accessories Systems Repairs (ATA VMRS 02-Cab and Sheet Metal, } \\
\text { 50-Accessories, 71-Body) }\end{array}$} \\
\hline Parts cost & $47,059.68$ & $14,576.35$ \\
\hline Labor hours & $3,550.6$ & $1,184.7$ \\
\hline Average labor cost & $177,531.50$ & $59,232.50$ \\
\hline Total cost (for system) & $224,591.18$ & $73,808.85$ \\
\hline Total cost (for system) per bus & $22,459.12$ & $7,380.89$ \\
\hline Total cost (for system) per mile & 0.12 & 0.14 \\
\hline \multicolumn{3}{|c|}{ HVAC System Repairs (ATA VMRS 01) } \\
\hline Parts cost & $7,490.69$ & $3,119.36$ \\
\hline Labor hours & 286.6 & 84.6 \\
\hline Average labor cost & $14,328.00$ & $4,230.50$ \\
\hline Total cost (for system) & $21,818.69$ & $7,349.86$ \\
\hline Total cost (for system) per bus & $2,181.87$ & 734.99 \\
\hline Total cost (for system) per mile & 0.01 & 0.01 \\
\hline
\end{tabular}


Breakdown of Maintenance Costs by Vehicle System (continued)

\begin{tabular}{|c|c|c|}
\hline & $\begin{array}{c}\text { Gillig Diesel } \\
7 / 13-12 / 16 \\
\text { (Data Period) }\end{array}$ & $\begin{array}{c}\text { Gillig Diesel } \\
\text { 1/16-12/16 } \\
\text { (Report Data } \\
\text { Period) }\end{array}$ \\
\hline \multicolumn{3}{|c|}{ Lighting System Repairs (ATA VMRS 34) } \\
\hline Parts cost & $5,245.44$ & $3,807.66$ \\
\hline Labor hours & 124.5 & 58.7 \\
\hline Average labor cost & $6,223.00$ & $2,937.00$ \\
\hline Total cost (for system) & $11,468.44$ & $6,744.66$ \\
\hline Total cost (for system) per bus & $1,146.84$ & 674.47 \\
\hline Total cost (for system) per mile & 0.01 & 0.01 \\
\hline \multicolumn{3}{|c|}{$\begin{array}{l}\text { Frame, Steering, and Suspension Repairs (ATA VMRS 14-Frame, 15-Steering, 16- } \\
\text { Suspension) }\end{array}$} \\
\hline Parts cost & $3,813.22$ & $3,559.30$ \\
\hline Labor hours & 182.3 & 114.2 \\
\hline Average labor cost & $9,115.00$ & $5,710.50$ \\
\hline Total cost (for system) & $12,928.22$ & $9,269.80$ \\
\hline Total cost (for system) per bus & $1,292.82$ & 926.98 \\
\hline Total cost (for system) per mile & 0.01 & 0.02 \\
\hline \multicolumn{3}{|c|}{$\begin{array}{l}\text { Axle, Wheel, and Drive Shaft Repairs (ATA VMRS 11-Front Axle, 18-Wheels, 22-Rear } \\
\text { Axle, 24-Drive Shaft) }\end{array}$} \\
\hline Parts cost & 777.56 & 60.68 \\
\hline Labor hours & 111.3 & 37.5 \\
\hline Average labor cost & $5,565.50$ & $1,874.50$ \\
\hline Total cost (for system) & $6,343.06$ & $1,935.18$ \\
\hline Total cost (for system) per bus & 634.31 & 193.52 \\
\hline Total cost (for system) per mile & 0.00 & 0.00 \\
\hline \multicolumn{3}{|l|}{ Tire Repairs (ATA VMRS 17) } \\
\hline Parts cost & 0.00 & 0.00 \\
\hline Labor hours & 35.3 & 9.5 \\
\hline Average labor cost & $1,766.50$ & 475.00 \\
\hline Total cost (for system) & $1,766.50$ & 475.00 \\
\hline Total cost (for system) per bus & 176.65 & 47.50 \\
\hline Total cost (for system) per mile & 0.00 & 0.00 \\
\hline
\end{tabular}




\section{Appendix F: Diesel Fleet Summary Statistics—SI Units}

\section{Gillig Diesel Fleet Operations and Economics}

\begin{tabular}{|l|r|r|}
\hline & \multicolumn{1}{|c|}{$\begin{array}{c}\text { Gillig Diesel } \\
7 / 13-12 / 16 \\
\text { (Data Period) }\end{array}$} & $\begin{array}{c}\text { Gillig Diesel } \\
1 / 16-12 / 16 \\
\text { (Report Data } \\
\text { Period) }\end{array}$ \\
\hline Number of vehicles & 10 & 10 \\
\hline Period used for fuel and oil op analysis & $7 / 13-12 / 16$ & $1 / 16-12 / 16$ \\
\hline Total number of months in period & 42 & 12 \\
\hline Fuel and oil analysis base fleet kilometers & $2,861,786$ & 824,393 \\
\hline Period used for maintenance op analysis & $7 / 13-12 / 16$ & $1 / 16-12 / 16$ \\
\hline Total number of months in period & 42 & 12 \\
\hline Maintenance analysis base fleet kilometers & $3,080,123$ & 842,018 \\
\hline Average monthly kilometers per vehicle & 7,334 & 7,017 \\
\hline Availability & $89 \%$ & $90 \%$ \\
\hline Fleet fuel usage (L) & $1,580,830$ & 460,185 \\
\hline Roadcalls & 287 & 87 \\
\hline KMBRC-all systems & 10,732 & 9,678 \\
\hline Propulsion roadcalls & 142 & 52 \\
\hline Propulsion KMBRC & 21,691 & 16,193 \\
\hline Representative fleet fuel consumption (L/100 & 55.24 & 55.82 \\
\hline km) & 0.60 & 0.41 \\
\hline Diesel cost/liter & $\mathbf{0 . 3 3}$ & $\mathbf{0 . 2 3}$ \\
\hline Fuel cost per kilometer & 0.08 & 0.09 \\
\hline Total scheduled repair cost per kilometer & 0.16 & 0.25 \\
\hline Total unscheduled repair cost per kilometer & $\mathbf{0 . 2 4}$ & $\mathbf{0 . 3 5}$ \\
\hline Total maintenance cost per kilometer & $\mathbf{0 . 5 7}$ & $\mathbf{0 . 5 7}$ \\
\hline Total operating cost per kilometer & & \\
\hline & &
\end{tabular}

\section{Maintenance Costs}

\begin{tabular}{|l|r|r|}
\hline & \multicolumn{1}{|c|}{$\begin{array}{r}\text { Gillig Diesel } \\
7 / 13-12 / 16 \\
\text { (Data Period) }\end{array}$} & $\begin{array}{r}\text { Gillig Diesel } \\
1 / 16-12 / 16 \\
\text { (Report Data } \\
\text { Period) }\end{array}$ \\
\hline Fleet kilometers & $3,080,123$ & 842,018 \\
\hline Total parts cost & $228,712.5$ & $106,128.7$ \\
\hline Total labor hours & $10,229.7$ & $3,697.7$ \\
\hline Average labor cost $@ \$ 50.00$ per hour) & $511,482.50$ & $184,885.00$ \\
\hline Total maintenance cost & $740,195.03$ & $291,013.73$ \\
\hline Total maintenance cost per bus & $74,019.50$ & $29,101.37$ \\
\hline Total maintenance cost per kilometer & $\mathbf{0 . 2 4}$ & $\mathbf{0 . 3 5}$ \\
\hline
\end{tabular}




\section{Appendix G: Diesel Monthly Maintenance Analysis Graphs}

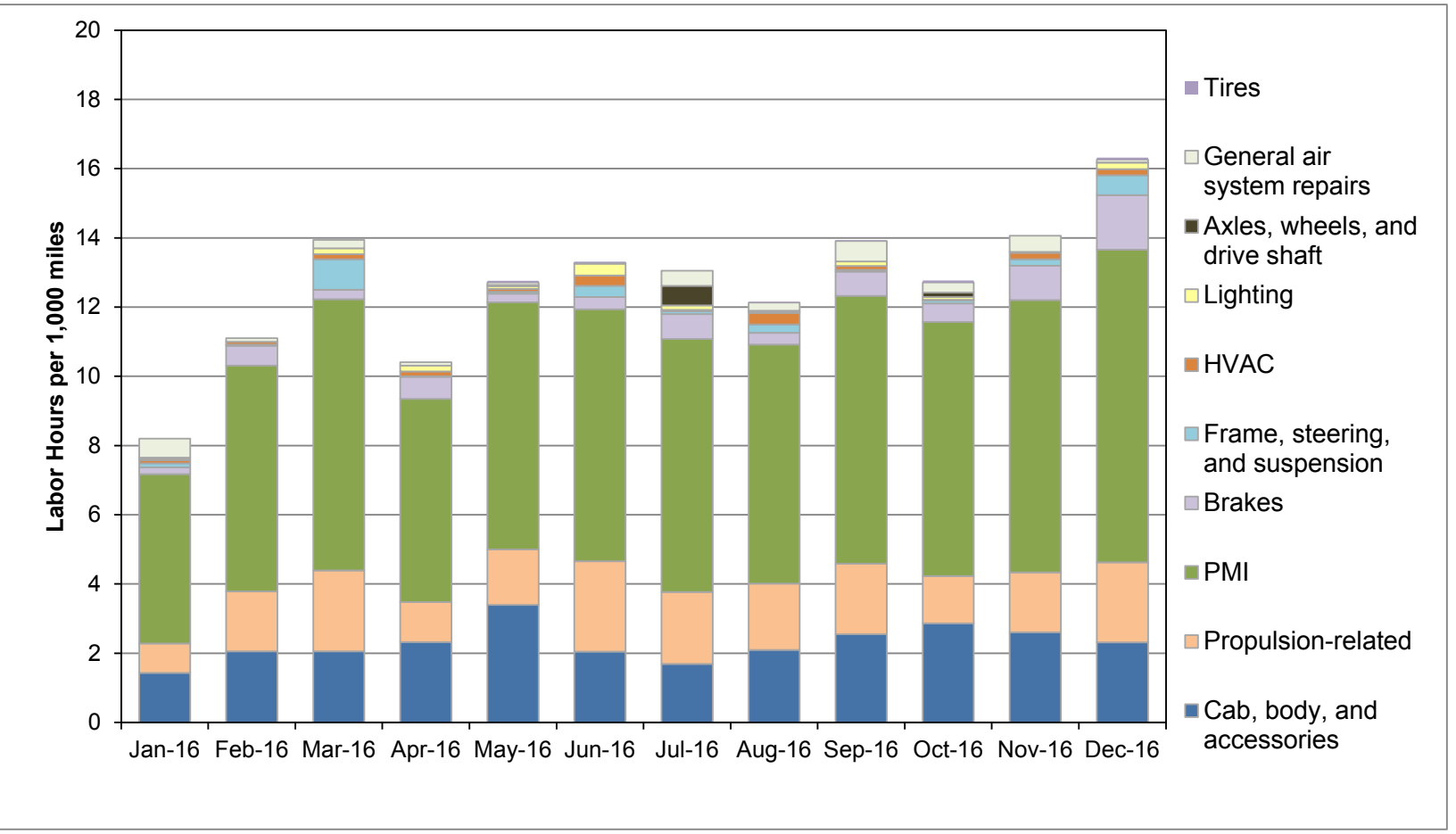

Figure G-1. Monthly labor hours by category for the Gillig diesel buses

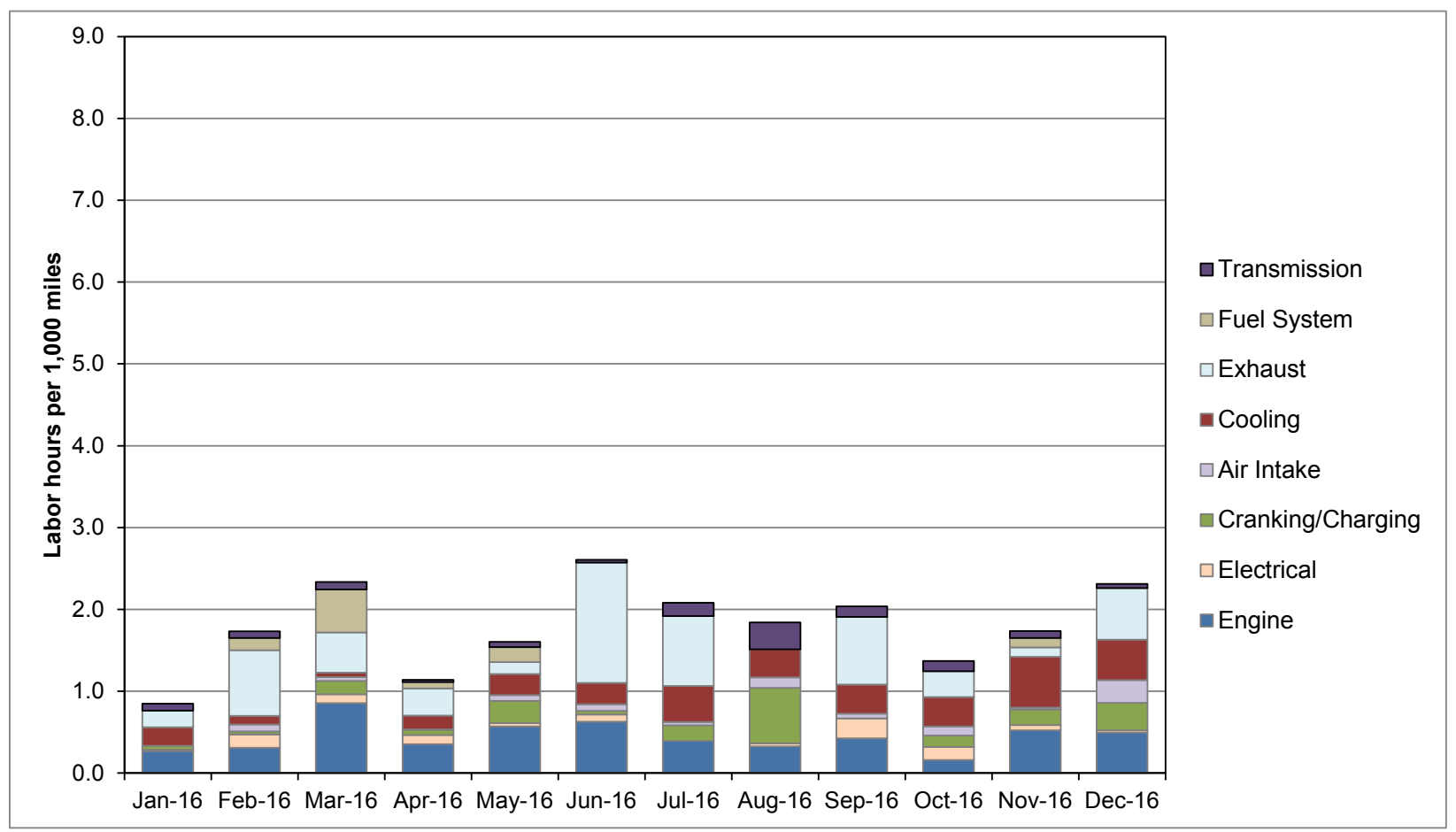

Figure G-2. Monthly propulsion system labor hours by subcategory for the Gillig diesel buses 


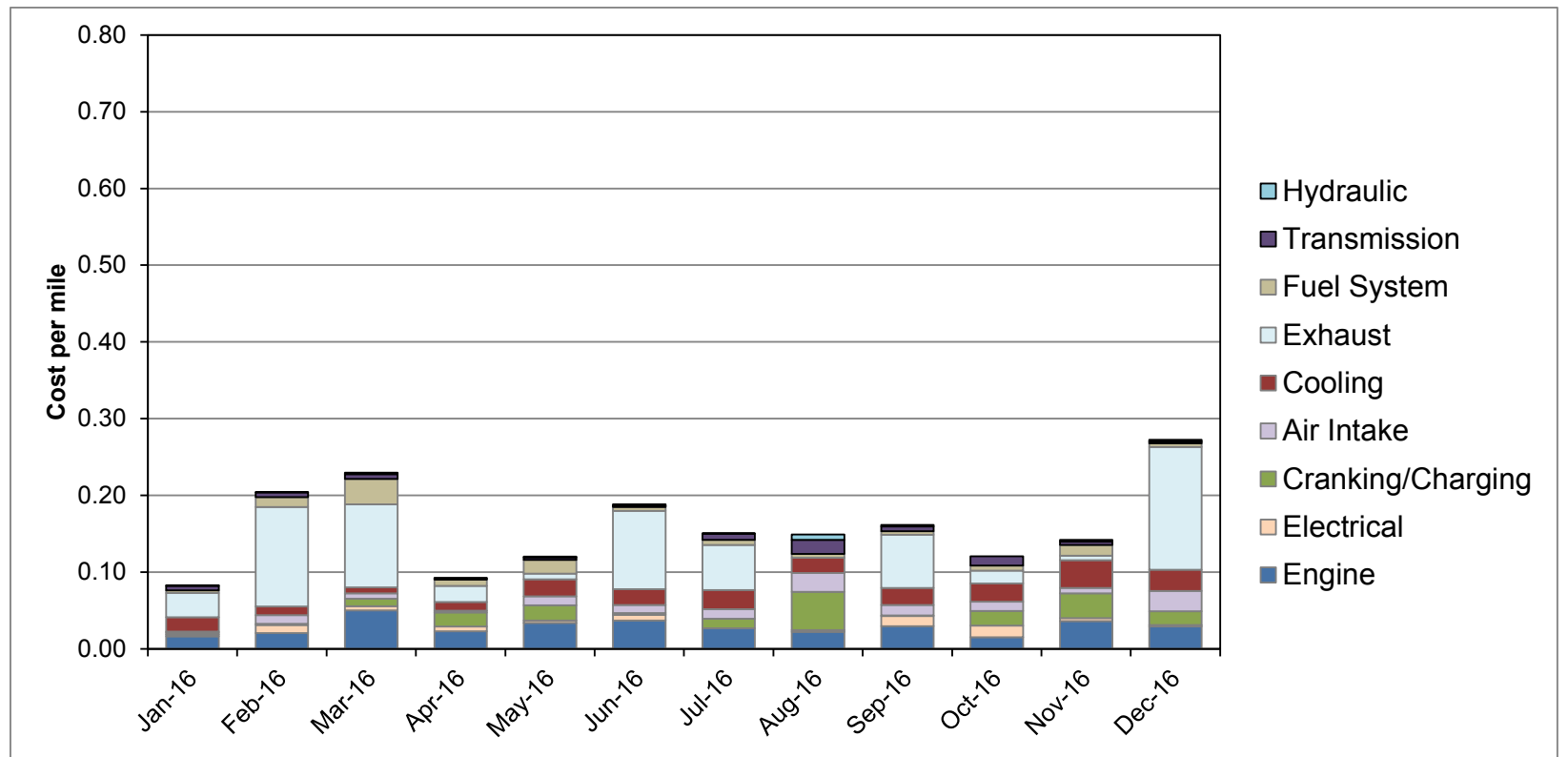

Figure G-3. Monthly propulsion system cost per mile by subcategory for the Gillig diesel buses 


\section{Appendix H: Charts for Entire In-Service Period (All Data)}

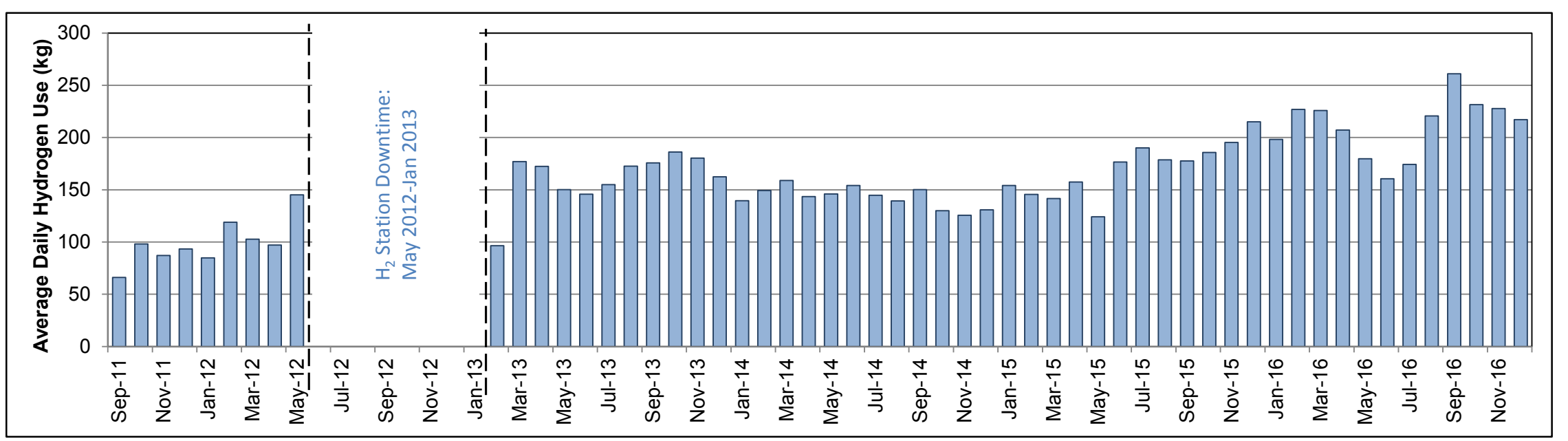

Figure H-1. Average hydrogen dispensed per day at AC Transit's hydrogen stations (excluding 0 kg days)

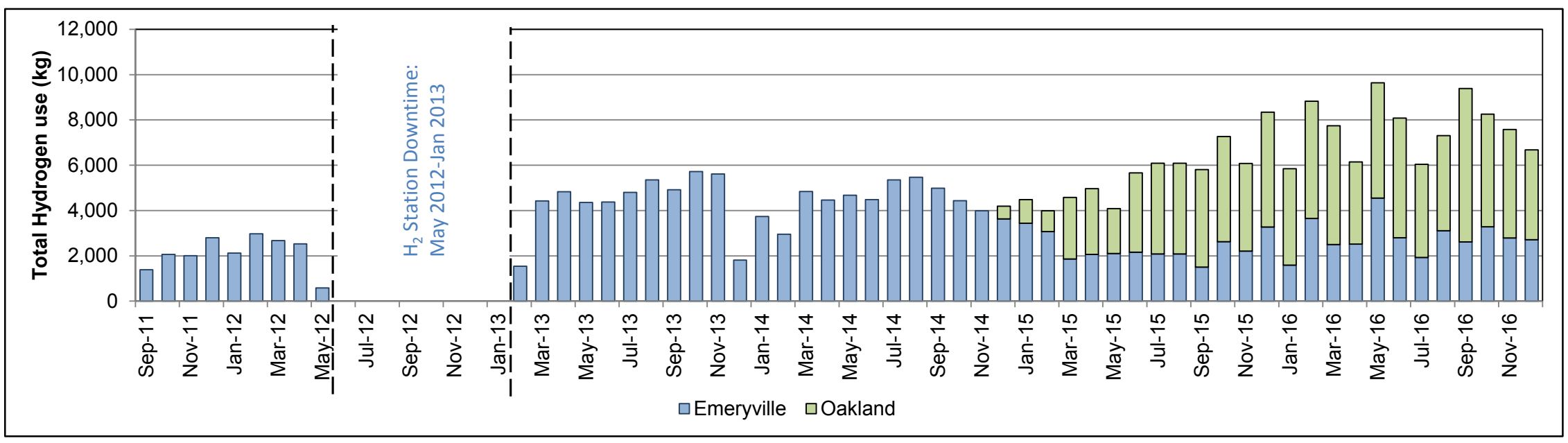

Figure H-2. Total hydrogen dispensed per month at AC Transit's hydrogen stations 


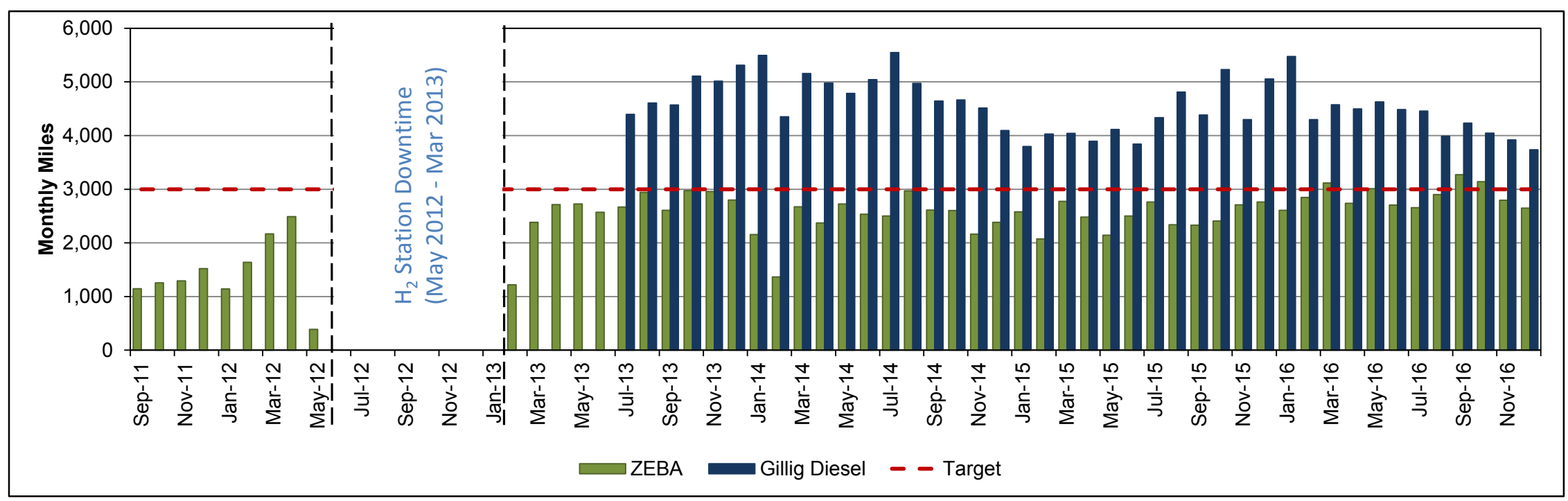

Figure H-3. Monthly average miles for the ZEBA FCEBs and Gillig diesel buses

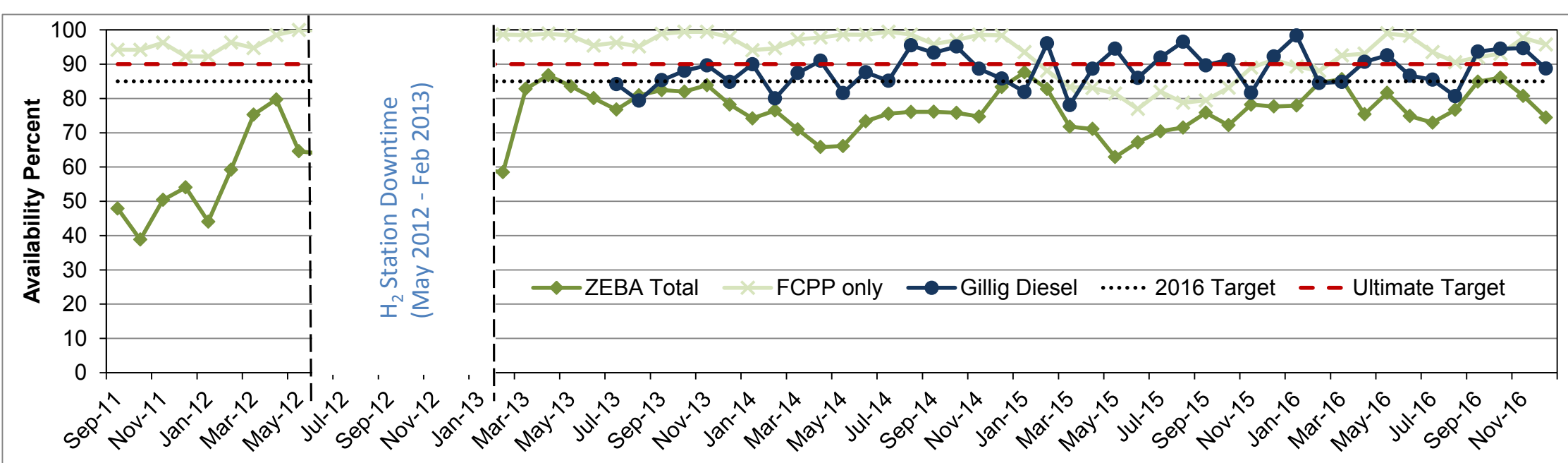

Figure H-4. Availability for the ZEBA FCEBs and Gillig diesel buses 


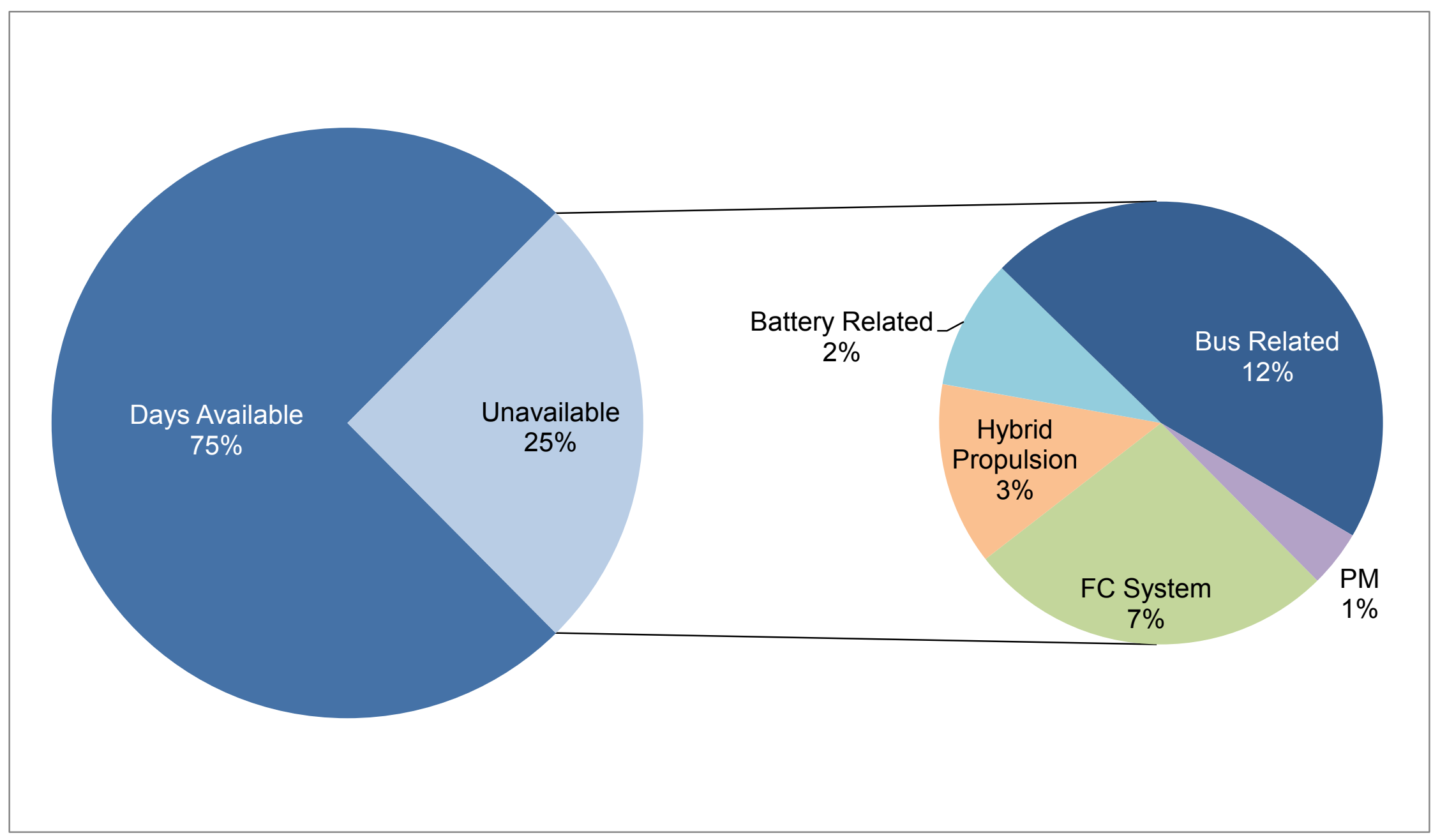

Figure H-5. Availability and unavailability by category for the FCEB fleet 


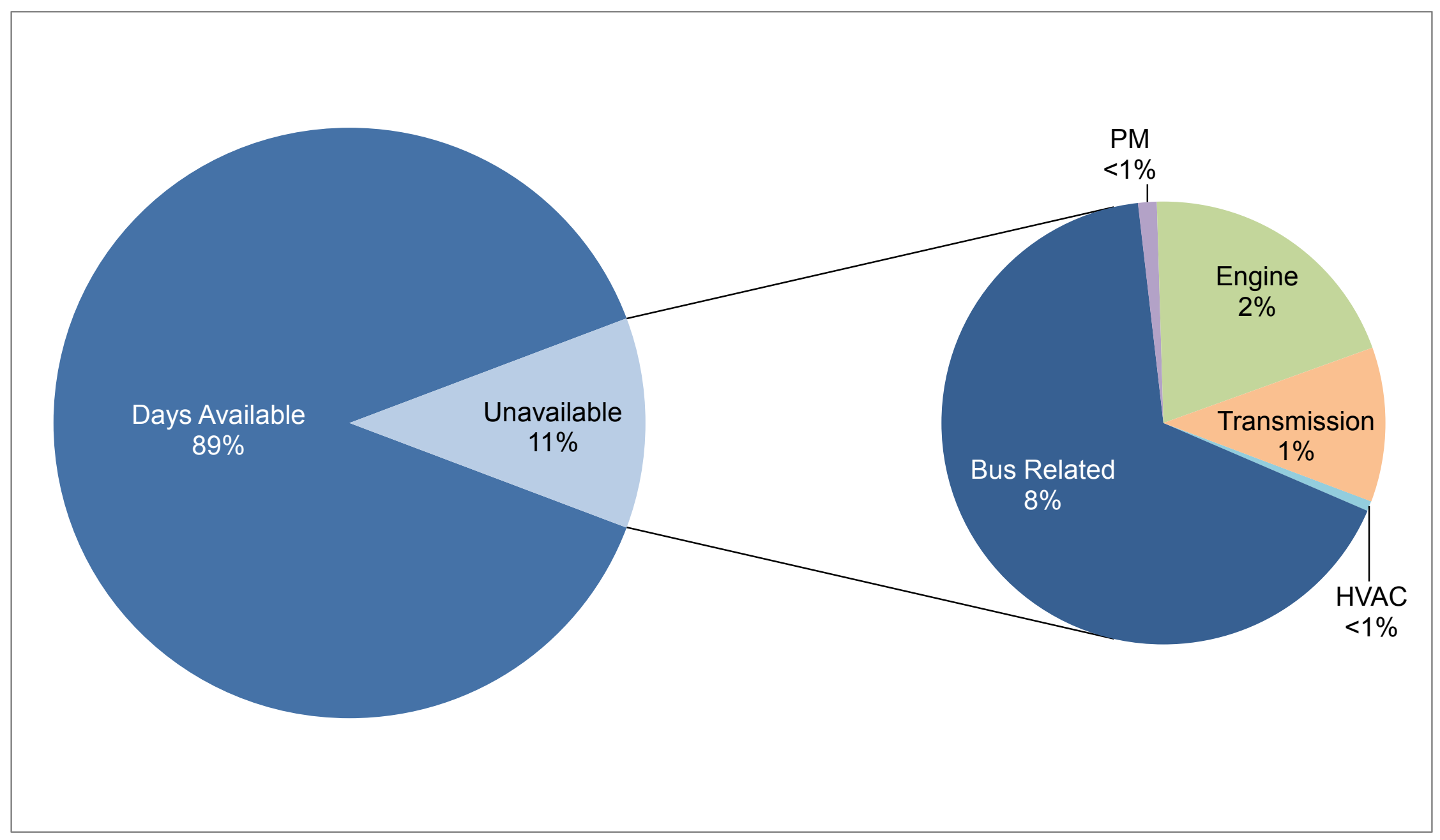

Figure H-6. Availability and unavailability by category for the Gillig diesel fleet 


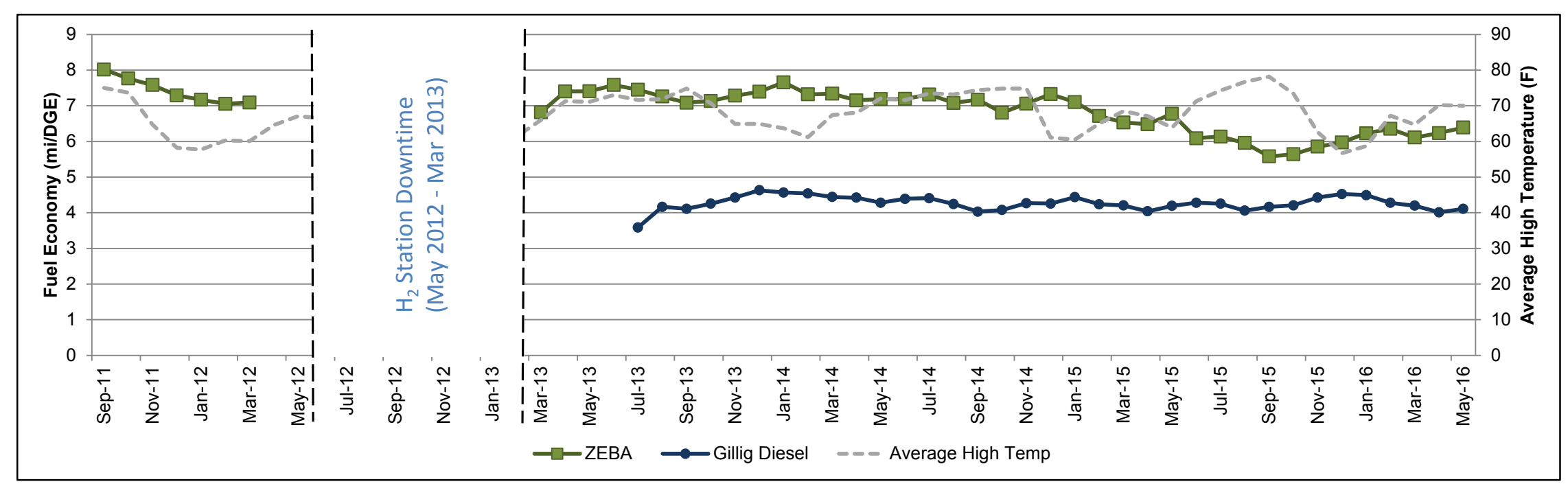

Figure H-7. Average fuel economy for the ZEBA FCEBs and Gillig diesel buses

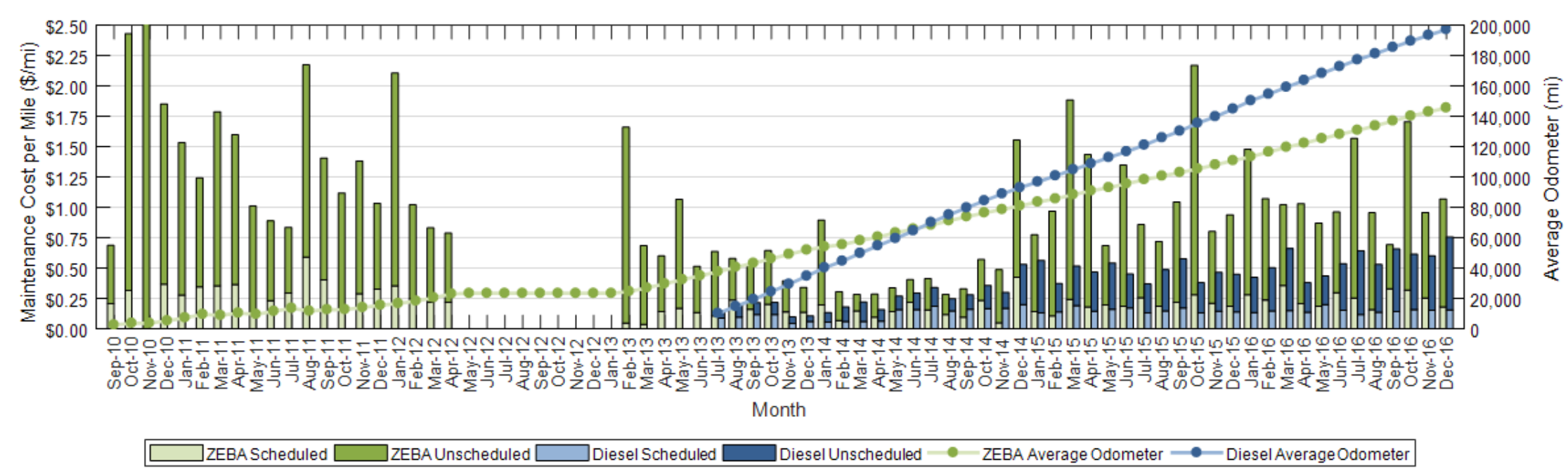

Figure H-8. Monthly scheduled and unscheduled costs per mile for the ZEBA FCEBs and Gillig diesel buses 


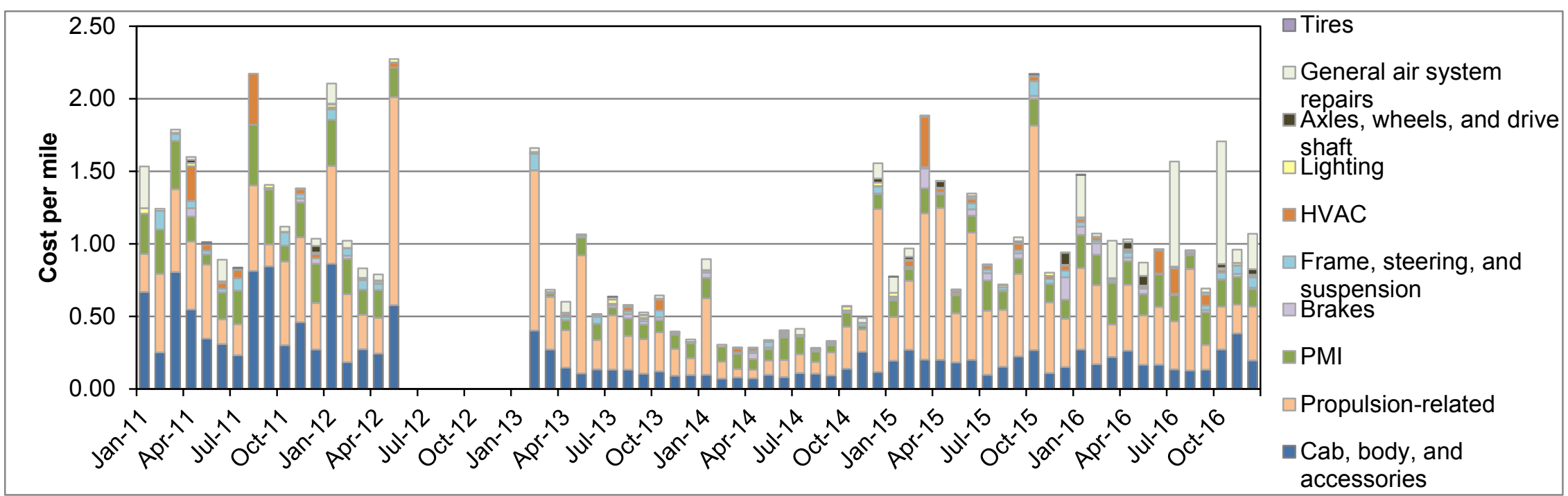

Figure H-9. Monthly cost per mile by category for the ZEBA FCEBs

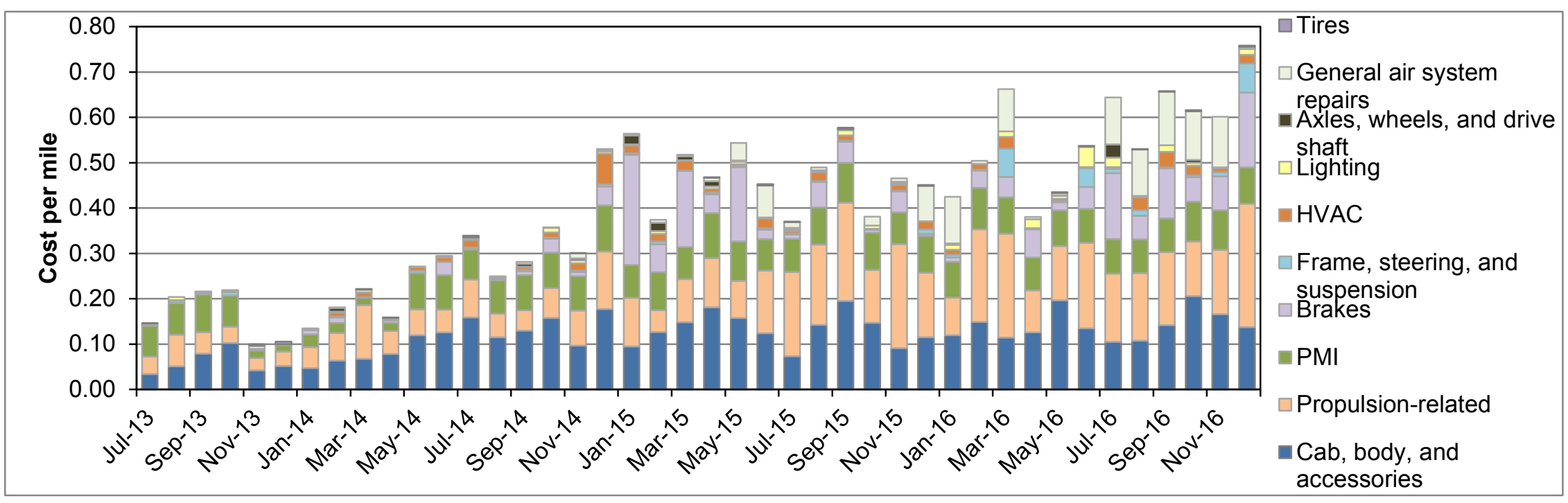

Figure H-10. Monthly cost per mile by category for the Gillig diesel buses 


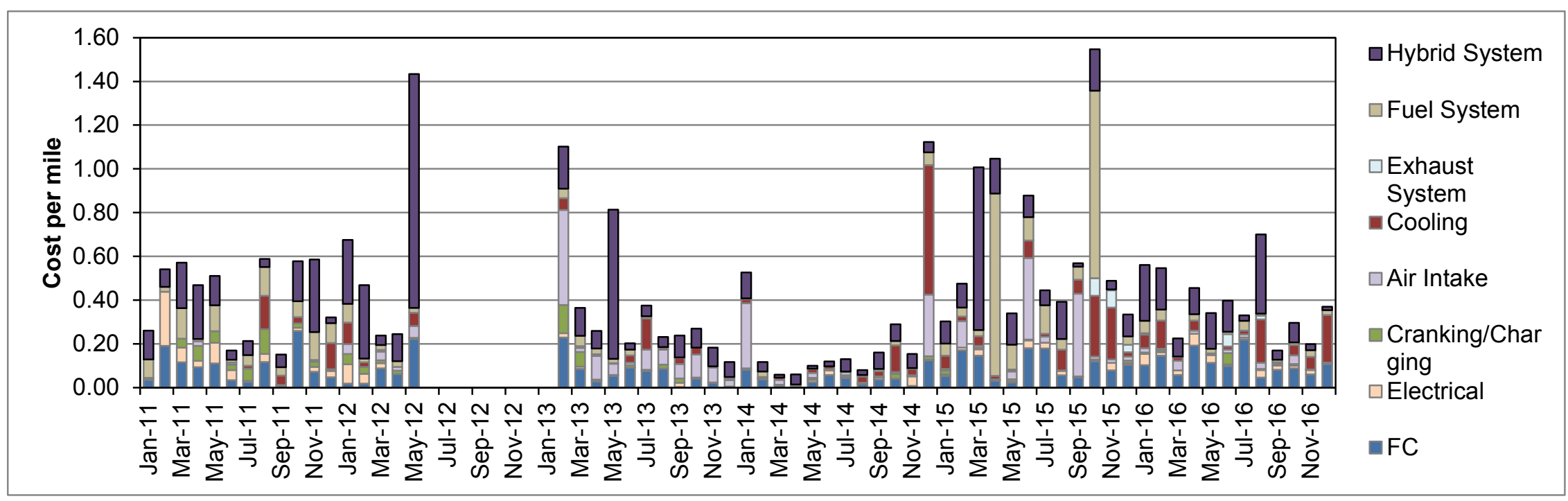

Figure H-11. Monthly propulsion system cost per mile by subcategory for the ZEBA FCEBs

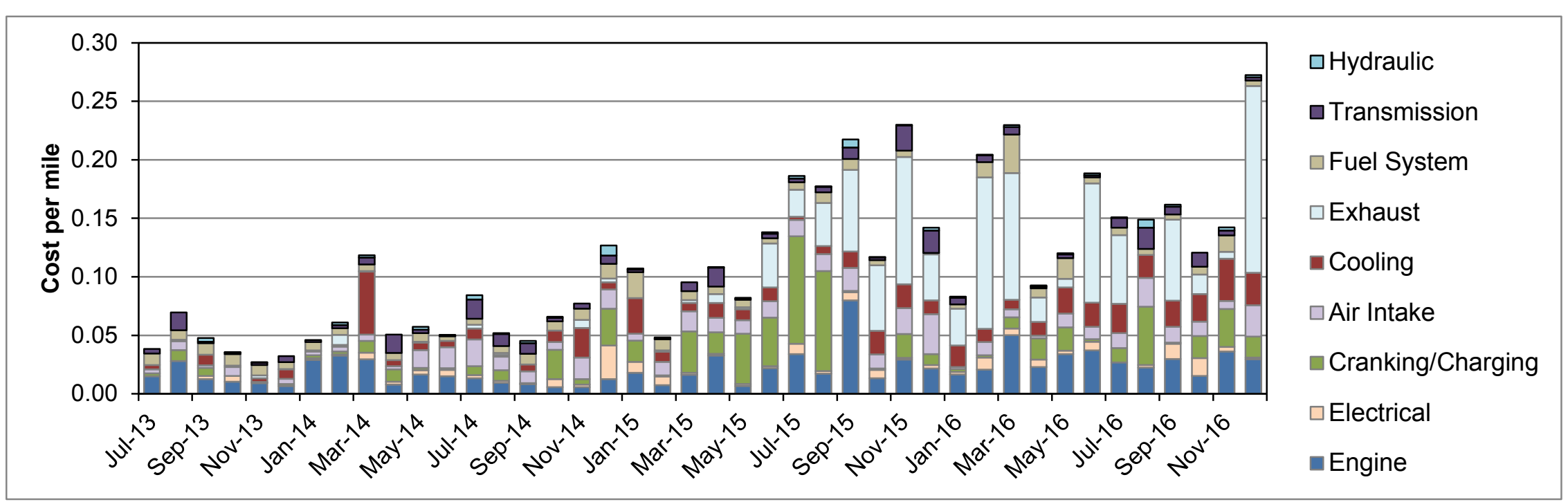

Figure H-12. Monthly propulsion system cost per mile by subcategory for the Gillig diesel buses 